\title{
Ground-Water and Surface-Water Relations along the Mojave River, Southern California
}

By GREGORY C. LINES

\section{U.S. GEOLOGICAL SURVEY}

Water-Resources Investigations Report 95-4189

Prepared in cooperation with the

MOJAVE WATER AGENCY

$$
\text { ำ }
$$




\section{U.S. DEPARTMENT OF THE INTERIOR \\ BRUCE BABBITT, Secretary}

U.S. GEOLOGICAL SURVEY

Gordon P. Eaton, Director

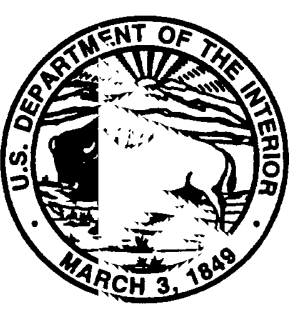

The use of firm, trade, and brand names in this report is for identification purposes only and does not constitute endorsement by the U.S. Geological Survey.

For addtional information write to:

District Chief

U.S. Geological Survey

Federal Building, Room W-2233

2800 Cottage Way

Sacramento, CA 95825
Copies of this report can be purchased from:

U.S. Geological Survey

Earth Science Information Center

Open-File Report Section

Box 25286, Mail Stop 417

Denver Federal Center

Denver, CO 80225 


\section{CONTENTS}

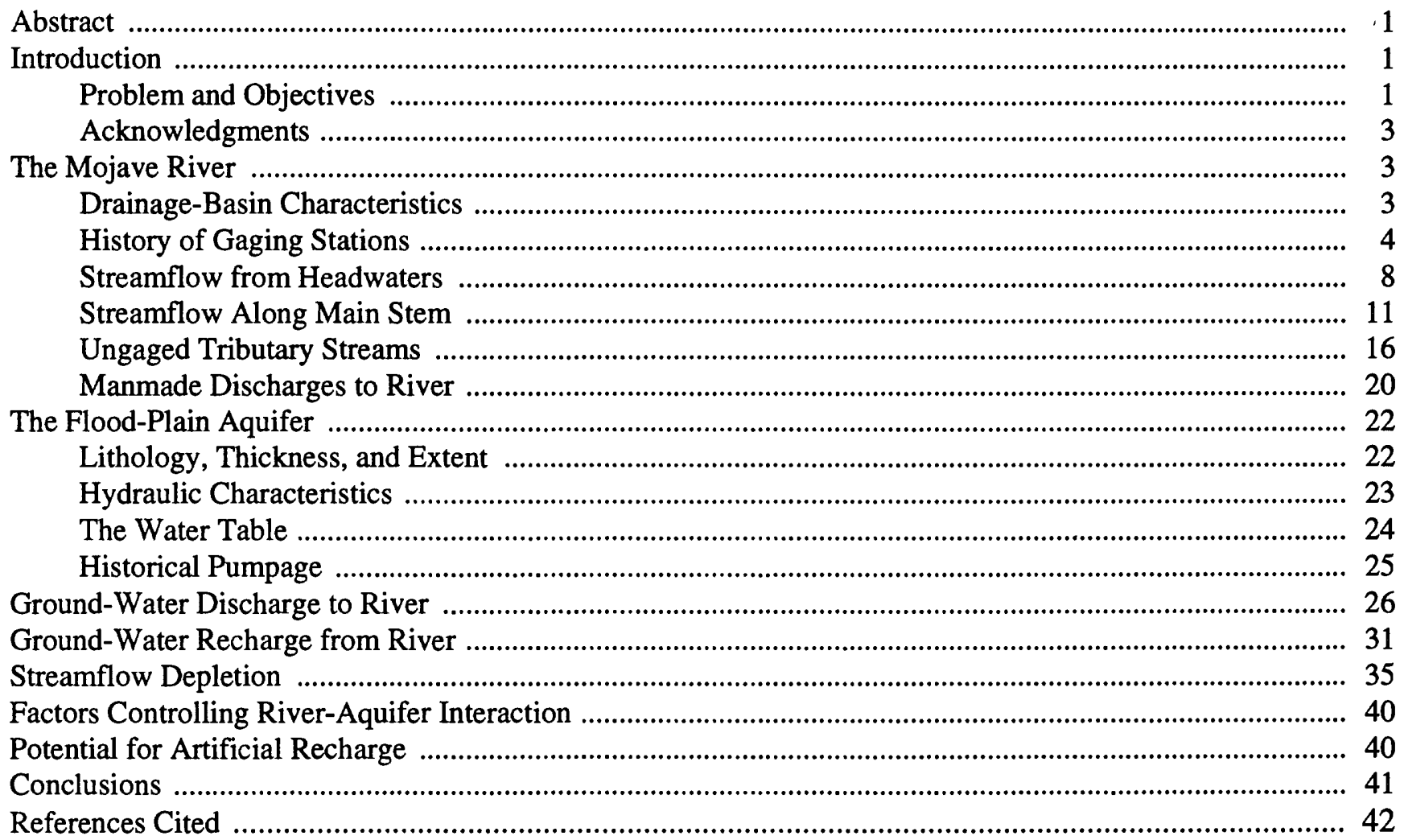

\section{FIGURES}

1. Map showing the Mojave River drainage basin

2,3. Graphs showing:

2. Annual precipitation in the headwaters of the Mojave River basin, water years 1931-94 .............................

3. Cumulative departure from mean precipitation in the headwaters of the Mojave River basin, water years 1931-94

4. Map showing gaging stations, channel-geometry sites, points of manmade discharge to river, and distance downstream from Mojave River Forks Reservoir

5-7. Photographs showing:

5. Gaging station 10261500, Mojave River at Lower Narrows, near Victorville, January 31, 1995 .................... 6

6. Gaging station 10262500, Mojave River at Barstow, January 18, 1993 ...................................................... 7

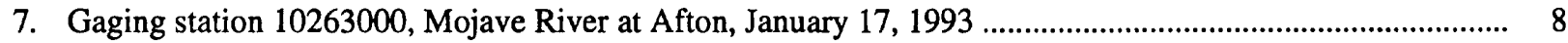

8-14. Graphs showing:

8. Flow duration for Deep Creek at gaging station 10260500 (water years 1931-71 and 1972-94) and for West Fork Mojave River at gaging stations 10261000 and 10260950 (water years 1931-71 and 1975-94).

9. Total annual inflow to main stem of Mojave River from the headwaters, water years 1931-94 
10. Exceedance probabilities and recurrence intervals for total annual inflow to main stem of Mojave River from the headwaters

11. Daily mean discharge at gaging station 10261500 , Mojave River at Lower Narrows, near Victorville, water years 1931-94

12. Daily mean discharge at gaging station 10262500 , Mojave River at Barstow, water years 1931-94

13. Daily mean discharge at gaging station 10263000, Mojave River at Afton, water years 1930- 2 , 1953-78, and 1981-94

14. Flow duration for the Mojave River near Victorville (gaging station 10261500), at Barstow

(gaging station 10262500), and at Afton Canyon (gaging station 10263000) during selected periods........

15. Diagram showing reaches of the main stem of the Mojave River that had streamflow during water years 1992-94.

16. Photograph showing channel-geometry measurement at site 10 on Bell Mountain Wash

7,18. Graphs showing:

17. Relation between channel width and annual mean discharge at 29 gaging stations in Mojave Desert region ..... Mojave River, February 25, 1993

20. Graph showing wastewater and fish hatchery discharges to the Mojave River, water years 1949-94.....
18. Estimated annual discharge of tributary streams along the main stem of the Mojave River and ratio of
annual to average discharge of the Mojave River at Barstow (gaging station 10262500), witer years
18. Estimated annual discharge of tributary streams along the main stem of the Mojave River and ratio of
annual to average discharge of the Mojave River at Barstow (gaging station 10262500), water years 1931-94
19. Photograph showing aerial view of California Department of Fish and Game fish hatchery and discharge to

21. Map showing altitude of the water table in the flood-plain aquifer, November 1991, and estimated specific yield

22. Profile showing altitude of Mojave River streambed and altitude of the water table, November 1991 and March 1993

23. Graph showing water levels in flood-plain aquifer at wells along the upper and middle main stem of the Mojave River, April 1992-September 1994

24. Diagram showing idealized streamflow-hydrograph separation.

25-28. Graphs showing:

25. Estimated stormflow and base flow for the Mojave River at Lower Narrows (gaging station 10261500) during water year 1982

26. Base flow of Mojave River near Victorville (gaging station 10261500) during water years 19()-01, 1904-05, and 1931-94

27. Base flow of Mojave River at Afton Canyon (gaging station 10263000) during water years 1930-32, 1953-78, and 1981-94

28. Cumulative annual recharge to the flood-plain aquifer from the Mojave River along the upper and middle main stem during water years 1931-94 and along the lower main stem during water years 1931-32 and 1953-94

29. Map showing areas of water-table rise along the Mojave River, November 1992 to March 1993.

30-35. Graphs showing:

30. Streamflow depletion by a well that is pumped continuously for one month 720 feet from a stream

31. Streamflow depletion by a well that is pumped continuously for 60 months for various stream-depletion factors and distances from a stream

32. Estimated streamflow depletion for Mojave River at Afton Canyon (gaging station 10263000) during water years $1985-87$

33. Estimated streamflow depletion for Mojave River at Lower Narrows (gaging station 1026150) during water years $1948-50$

34. Streamflow depletion of Mojave River at Afton Canyon (gaging station 10263000) caused mainly by evapotranspiration during selected water years .

35. Streamflow depletion of Mojave River at Lower Narrows (gaging station 10261500) caused kv groundwater pumping and evapotranspiration during selected water years

36. Photograph showing Mojave Water Agency's release of imported water to upper main stem of Mojave

River near river mile 4, August 29, 1994 


\section{TABLES}

1. Annual mean discharge and channel width at 29 gaging stations in the Mojave Desert region

2. Channel width and estimated annual mean discharge and runoff in selected ephemeral tributary streams to the Mojave River

3. Estimated annual recharge to the flood-plain aquifer from the Mojave River, water years 1931-94

CONVERSION FACTORS, DEFINITION OF WATER YEAR, AND VERTICAL DATUM

\begin{tabular}{rcl}
\hline Multiply & By & To obtain \\
\hline acre & 0.4047 & hectare \\
acre-foot (acre-ft) & 1,233 & cubic meter \\
acre-foot per year (acre-ft/yr) & 0.001233 & cubic hectometer per year \\
cubic foot per second $\left(\mathrm{ft}^{3} / \mathrm{s}\right)$ & 0.02832 & cubic meter per second \\
foot $(\mathrm{ft})$ & 0.3048 & meter \\
foot squared per day $\left(\mathrm{ft}^{2} / \mathrm{d}\right)$ & 0.0929 & meter squared per day \\
gallon per minute $(\mathrm{gal} / \mathrm{min})$ & 0.06308 & liter per second \\
inch (in.) & 25.4 & millimeter \\
mile (mi) & 1.609 & kilometer \\
square mile (mi $\left.{ }^{2}\right)$ & 2.590 & square kilometer \\
\hline
\end{tabular}

\section{Definition of Water Year}

A water year is the 12-month period October 1 through September 30 . The water year is designated by the calendar year in which it ends. Thus, the water year ending September 30, 1994, is called water year 19?4.

\section{Vertical Datum}

Sea level: In this report, "sea level" refers to the National Geodetic Vertical Datum of 1929-a geodetic datum derived from a general adjustment of the first-order level nets of the United States and Canada, forme-ly called Sea Level Datum of 1929. 


\title{
GROUND-WATER AND SURFACE-WATER RELATIONS ALONG THE MOJAVE RIVER, SOUTHERN CALIFORNIA
}

\author{
By Gregory C. Lines
}

\section{Abstract}

The Mojave River and the associated floodplain aquifer are important water supplies in the Mojave Desert of Southern California. The river and aquifer, in many areas, are in excellent hydraulic connection, and when flow conditions change in one, the other almost always is affected.

To better understand these relations, records of gaging stations were analyzed to determine the frequency and duration of historical streamflow. Annual ground-water recharge from the river during water years 1931-94 was estimated from an accounting of all streamflow accretions and losses. Annual recharge ranged from about 24,000 to 460,000 acre-feet and averaged about 96,000 acre-feet. Channel-geometry regression techniques were used to estimate runoff of ungaged ephemeral streams that are tributary to the river. Water-table and gravity changes were used to estimate specific yield of the aquifer and changes in ground-water storage following storm runoff during the winters of 1992-94. In addition, streamflow hydrographs were analyzed to estimate both ground-water discharge to the river (base flow) and historical streamflow depletion caused by ground-water pumping and evapotranspiration. Ground-water pumpage from the flood-plain aquifer was about 120,000 acre-feet during water year 1994. Annual evapotranspiration along the river probably ranges from about 10,000 to 30,000 acre-feet.
Factors controlling the exchange of water are identified in this report on the basis of the historical response of the river-aquifer system to stress (stormflows and pumping). Also identified are reaches of the river that are hydraulically suitable for artificial recharge.

\section{INTRODUCTION}

\section{Problem and Objectives}

The Mojave River (fig. 1) has long been the "lifeblood" of the Mojave Desert. For the Vany'ume and Chemehuevi Indians who lived along the river, water was the critical element for survival. River water and the vegetation that grew on the flood plain also were vital to the Spanish explorers of the late 1700 's, the American trappers of the early $180 \mathrm{C}$ 's, and the thousands of pioneers who later followed the Spanish Trail and Mormon Road (Walker, 1986).

By the 1880 's, boosted by the Calico mining boom and completion of a transcontinental railroad, Euro-American settlement along the Mojave River was expanding (Earle, 1992). But with a heavy reliance on river water and natural subirrigatior. agriculture along the river was devastated by the drought of 1894-1904. With the advent of combustion engines (and later, electric motors) to p pwer pumps, a "new" source of water became availal le. Instead of having to rely on the flow of the rive" and rainfall, users obtained large quantities of water from wells tapping sand and gravel beneath the flood plain (flood-plain aquifer). It seemed that the problems associated with an unpredictable water supply $\mathrm{rd}$ been solved. 
However, it soon became apparent from the fluctuation of water levels in wells that the replenishment of the flood-plain aquifer was dependent on seepage from the river (Thompson, 1929, p. 490-494) and that this new supply of water thus was limited. As pumpage increased, the relation between the river and aquifer became even more apparent. Reaches of the river previously having perennial flow now flowed only in response to storm runoff. As the 20th century comes to a close and the demand for water continues to increase, the ground-water system in the Mojave River basin is recognized as being in an overdraft condition. Water rights in the basin currently (1995) are being determined by adjudication.

Future management of the water resources and the implementation of measures to mitigate the over- draft conditions will benefit from a greater understanding of ground-water and surface-water relations along the Mojave River. In 1991, the Mojave Water Agency and the U.S. Geological Survey (USGS) began a 4-year cooperative study with the following objectives:

(1) Determine the sources and quantities of historical ground-water recharge and discharge along the Mojave River,

(2) Determine the effects of ground-water pumping on flow in the river (streamflow depletion),

(3) Determine the hydraulic factors controlling interaction between the river and the floodplain aquifer, and

(4) Determine which reaches of the river are hydraulically suitable for artificial recharge.

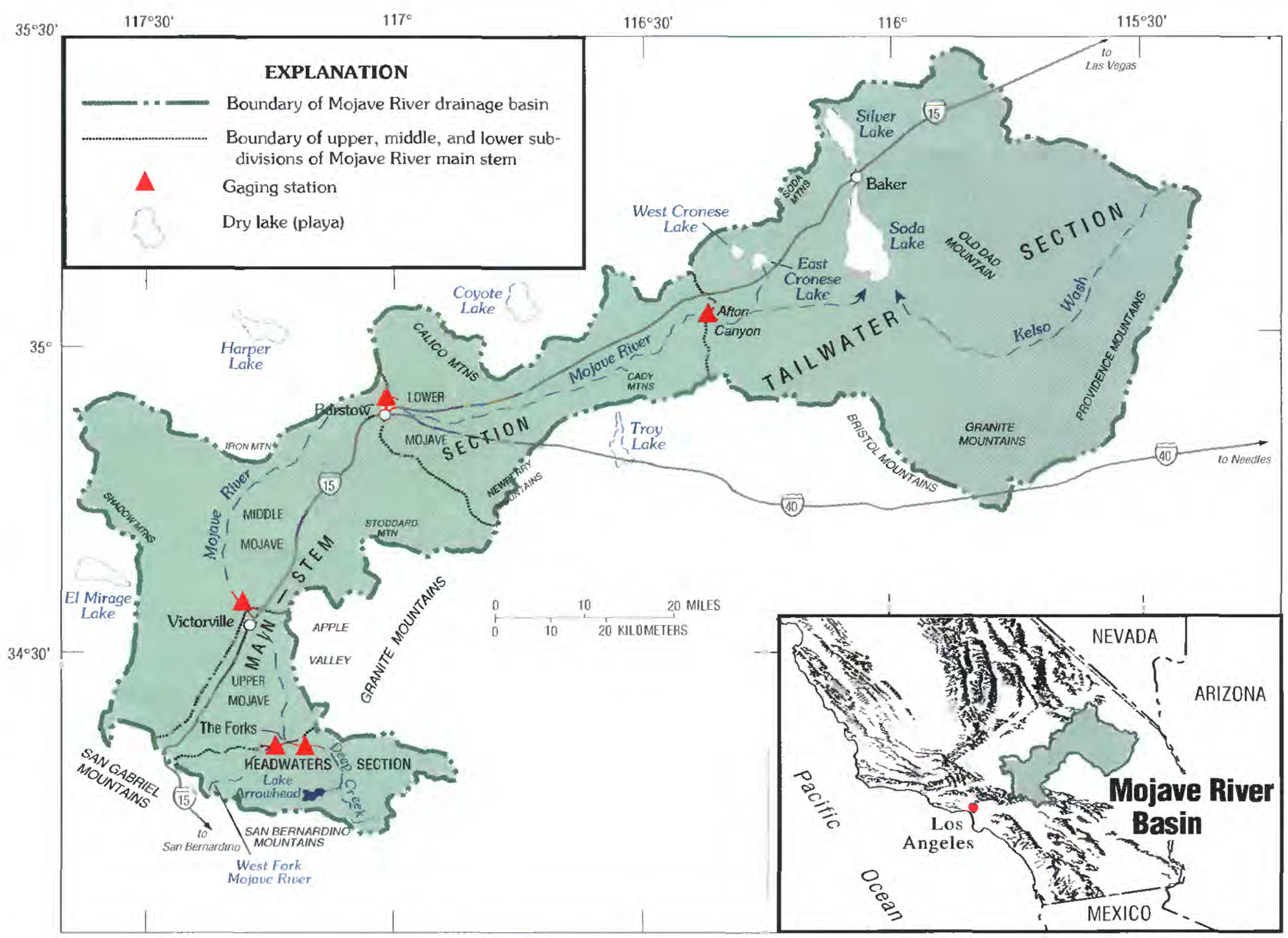

Figure 1. The Mojave River drainage basin. 
The study area includes the 100-mile reach of the Mojave River from the confluence of Deep Creek and West Fork Mojave River downstream to Afton Canyon (fig. 1). The purpose of this report is to summarize the results of the 4-year study.

\section{Acknowledgments}

The author expresses his gratitude to the many land owners in the area who supplied information on their wells and allowed access to their property for various measurements. Through conversations with many of these same people, the author gained a valuable historical perspective of water development and flow conditions of the Mojave River. Appreciation also is expressed to the California Department of Fish and Game and the Victor Valley Wastewater Reclamation Authority for supplying information on their discharges to the river. Thanks also are given to personnel of the Mojave River Valley Museum and the San Bernardino County Museum for allowing the author to review their photographic files and other historical reference materials.

\section{THE MOJAVE RIVER}

\section{Drainage-Basin Characteristics}

The Mojave River is formed by the junction of Deep Creek and West Fork Mojave River at The Forks at the northern foot of the San Bernardino Mountains (fig. 1). From The Forks, the river flows generally northward through the city of Victorville, then generally north and northeastward through the city of Barstow, and, eventually, through Afton Canyon. After emerging from Afton Canyon, the river splits and separate channels lead to East Cronese Lake and Soda Lake, both of which are dry playas except after major storms. During very wet winters, such as 1983 and 1993, water from Soda Lake flows into Silver Lake. To the author's knowledge, no water has flowed from East Cronese Lake into West Cronese Lake in historical times. Local residents report that during the winter of 1983, the Mojave River overflowed its banks between Iron Mountain and Barstow, and part of the river water flowed north-northwestward into Harper Lake (not generally considered a part of the river basin).

To aid in discussion of the hydrology, the author has divided the Mojave River basin into headwaters, main-stem, and tailwater sections (fig. 1). The headwaters section includes the Deep Creek and West Fork drainage basins above The Forks. The main-stem section includes that part of the Mojave River basin between The Forks and Afton Canyon. The mainstem section, which is the primary focus of this report, has been further divided into upper, middle, and lower parts on the basis of the location of USGS gaging stations. The tailwater section downstream from Afton Canyon was not a part of the study.

The drainage area of the Mojave River basin at the mouth of Afton Canyon is about 2,121 $\mathrm{mi}^{2}$ (Mullen and others, 1994, p. 109). However, included in that area is about $120 \mathrm{mi}^{2}$ of internal surface drainage in Apple Valley and about $400 \mathrm{mi}^{2}$ of internal surface drainage to Troy Lake. Thus, the area contributing surface runoff to the river at Afton Canyon is, at most, about $1,600 \mathrm{mi}^{2}$ (fig. 1). The headwaters section includes about $210 \mathrm{mi}^{2}$ (13 percent) of this contributing drainage area, the upper main stem about $180 \mathrm{mi}^{2}(11$ percent), the middle main stem about $780 \mathrm{mi}^{2}$ (49 percent), and lower main stem about $430 \mathrm{mi}^{2}$ (27 percent).

The altitude of the mountainous headwaters section ranges from about $2,960 \mathrm{ft}$ above sea level at The Forks to about $8,535 \mathrm{ft}$ at Butler Peak in the Deep Creek drainage basin. The altitude of the Mojave River streambed is about $2,700 \mathrm{ft}$ at Victorville, 2,100 $\mathrm{ft}$ at Barstow, and $1,400 \mathrm{ft}$ near the mouth of Afton Canyon. The slope of the main stem of the Mojave River, on the basis of measured distances between topographic contours on USGS maps, ranges from 7 to $42 \mathrm{ft} / \mathrm{mi}$ and averages about $16 \mathrm{ft} / \mathrm{mi}$.

Large areal variations in precipitation occur within the Mojave River basin. In the headwaters section, mean annual precipitation may exceed 40 in. Annual precipitation at the Squirrel Inn II station at an altitude of 5,750 ft (water years 1931-40) and at the Lake Arrowhead station (water years 1941-94) at an altitude of about $5,200 \mathrm{ft}$ is shown in figure 2. Combining the precipitation records of these two stations, both of which are at altitudes near the mean altitude of the headwaters section, gives a mean annual precip- 
itation for the 64 years of record of about 42 in. In contrast, mean annual precipitation is about $6 \mathrm{in}$. at Victorville and about 4 in. at Barstow and Afton Canyon (James, 1992).

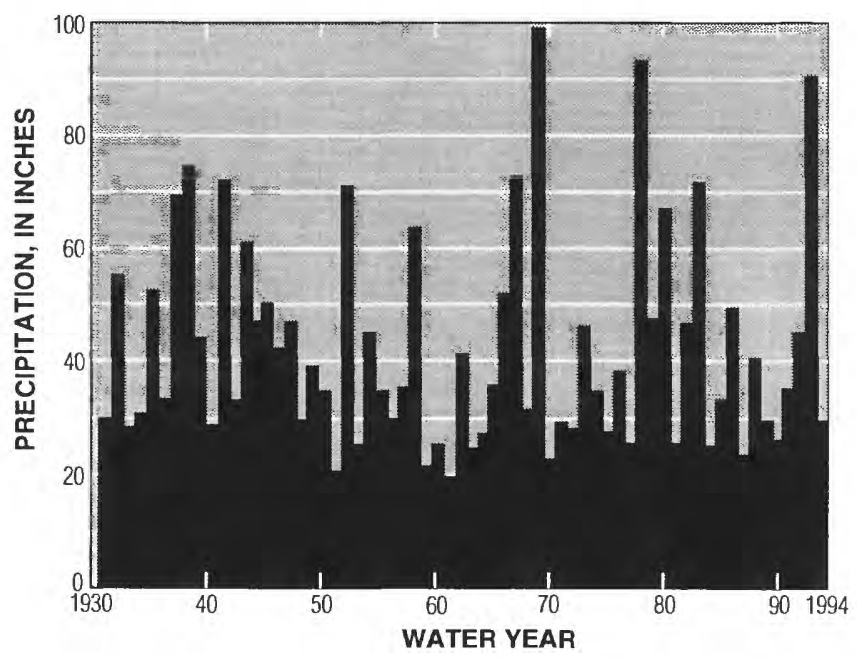

Figure 2. Annual precipitation in the headwaters of the Mojave River basin, water years 1931-94. (Squirrel Inn II, 1931-40; Lake Arrowhead, 1941-94.)

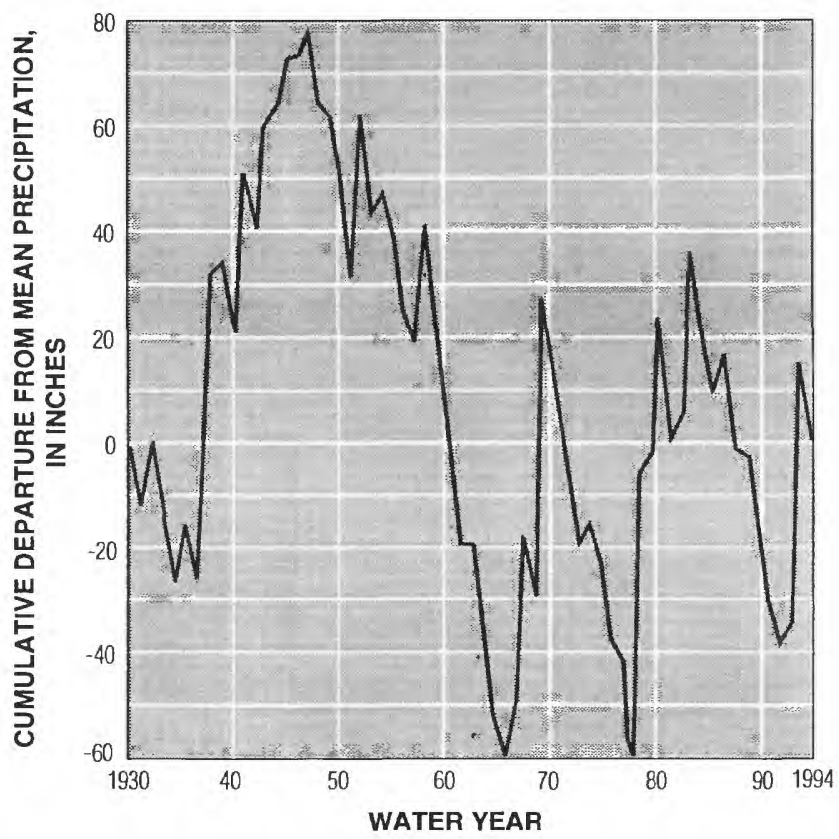

Figure 3. Cumulative departure from mean precipitation in the headwaters of the Mojave River basin, water years 1931-94.
As will be illustrated later in this report, precipitation and runoff in the headwaters section of the Mojave River basin greatly influence flow along the main stem of the river. A graph (fig. 3) of cumulative departure from mean precipitation at the Squirrel Inn II and Lake Arrowhead stations shows relative wet and dry periods in the headwaters during water years 1931-94. Upward-sloping sections of the graph indicate years when annual precipitation exceeded the mean. Conversely, downward-sloping sections of the graph indicate years when annual precipitation was less than the mean. For example, a dry period during water years 1948-65 had only three years of "above-normal" precipitation. The graph also shows that the recent drought (water years 1984-91) that markedly diminished California's water supply had the same duration but was less severe than the drought during 1970-77, at least in the headwaters of the Mojave River basin.

Several lakes and a reservoir partially regulate streamflows in the headwaters section of the basin. Lake Arrowhead (capacity 48,000 acre-ft) in the Deep Creek drainage basin and Lake Gregory (capacity 2,070 acre-ft) in the West Fork drainage basin are used primarily for recreation, and both slightly regulate streamflows during summer. Silverwood Lake (capacity 78,000 acre-ft), also in the West Fork drainage basin, was completed in 1971, mainly as a temporary holding reservoir for water imported via the California Aqueduct. Natural streamflow into Silverwood Lake is released through Cedar Springs Dam into West Fork as soon as possible after storms. The Mojave River Forks Reservoir (capacity 89,700 acre-ft) at the confluence of Deep Creek and West Fork also was completed in 1971 and is used for flood control. No water is impounded in the reservoir except during extreme flooding, and then only for a few hours.

\section{History of Gaging Stations}

Much of the description in this report regarding surface-water hydrology is based on discharge records from USGS gaging stations (fig. 4) in the headwaters section and along the main stem of the Mojave River. Because these records are such an integral part of the analysis, a brief historical summary of these gaging stations follows. 
The USGS has operated gaging station 10260500, Deep Creek near Hesperia, since water year 1930. The station is located about $1 \mathrm{mi}$ upstream from the confluence with West Fork Mojave River (fig. 4). The drainage area of Deep Creek at the station is $134 \mathrm{mi}^{2}$.

Two gaging stations have been operated on West Fork Mojave River near The Forks. The first, 10261000, West Fork Mojave River near Hesperia, was located about $0.5 \mathrm{mi}$ above the confluence with Deep Creek. At this location, the gage was operated by the USGS during water years 1930-1971, prior to the construction of Cedar Springs Dam and Mojave River Forks Reservoir. The second station, 10260950, West Fork Mojave River above Mojave River Forks Reservoir, near Hesperia, is located about $0.6 \mathrm{mi}$ upstream from the first station. It has been operated since water year 1975. Although the drainage areas of

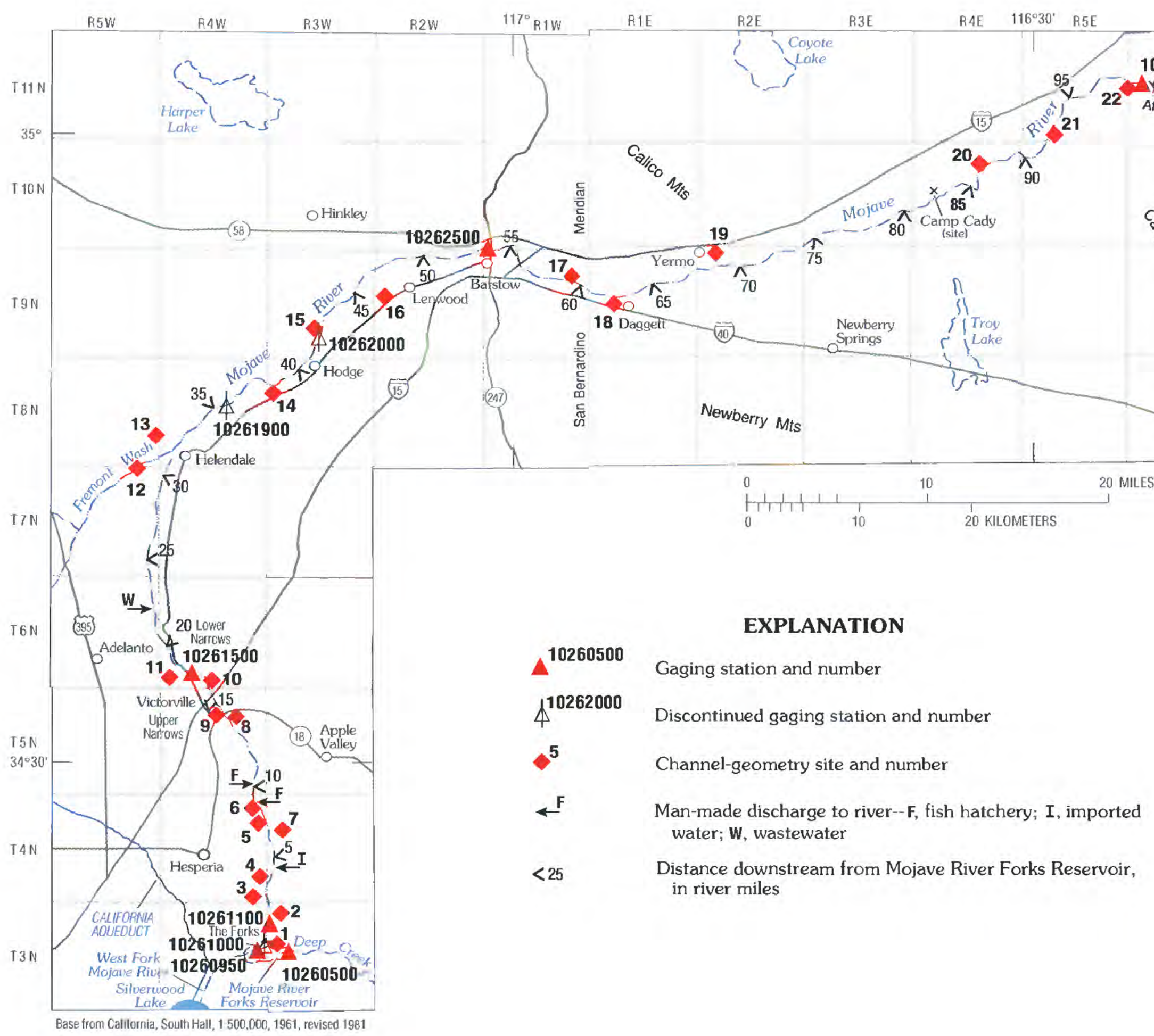

Figure 4. Gaging stations, channel-geometry sites, points of manmade discharge to river, and distance downstream from Mojave River Forks Reservoir. 
the first and second stations are 74.8 and $70.3 \mathrm{mi}^{2}$, respectively, streamflow for all practical purposes is equivalent at the two sites, except perhaps for a few hundred acre-feet of storm runoff from the $4.5-\mathrm{mi}^{2}$ area between the stations.

On the main stem of the Mojave River, $0.8 \mathrm{mi}$ downstream from the confluence of Deep Creek and West Fork, gaging station 10261100, Mojave River below Mojave River Forks Reservoir, near Hesperia, was operated during water years 1972-74. The station was inactive during water years 1975-79, and it was reactivated during water year 1980 . Drainage area at the station is $211 \mathrm{mi}^{2}$.

Gaging station 10261500, Mojave River at Lower Narrows, near Victorville (fig. 5), was operated during water years 1900-06 and 1931-36 at the Upper Narrows about 3 mi upstream from its present location where it has been in operation since December 9 ,
1936. Drainage area at the current location is $513 \mathrm{mi}^{2}$, which includes about $120 \mathrm{mi}^{2}$ of noncontributing internal drainage in Apple Valley.

Gaging station 10261900, Mojave River at Wild Crossing, near Helendale, was operated during water years 1967-70. About 7 mi farther downstream, gaging station 10262000, Mojave River near Hodge, was operated during water years 1931-32 and 197193. Both stations were discontinued because of unstable controls and changing stage-discharge relations that did not allow for acceptable discharge records.

The Mojave River at Barstow (fig. 6) has been measured at gaging station 10262500 since water year 1931. Drainage area of the Mojave River at the station is $1,291 \mathrm{mi}^{2}$, which includes about $120 \mathrm{mi}^{2}$ of noncontributing area in Apple Valley.

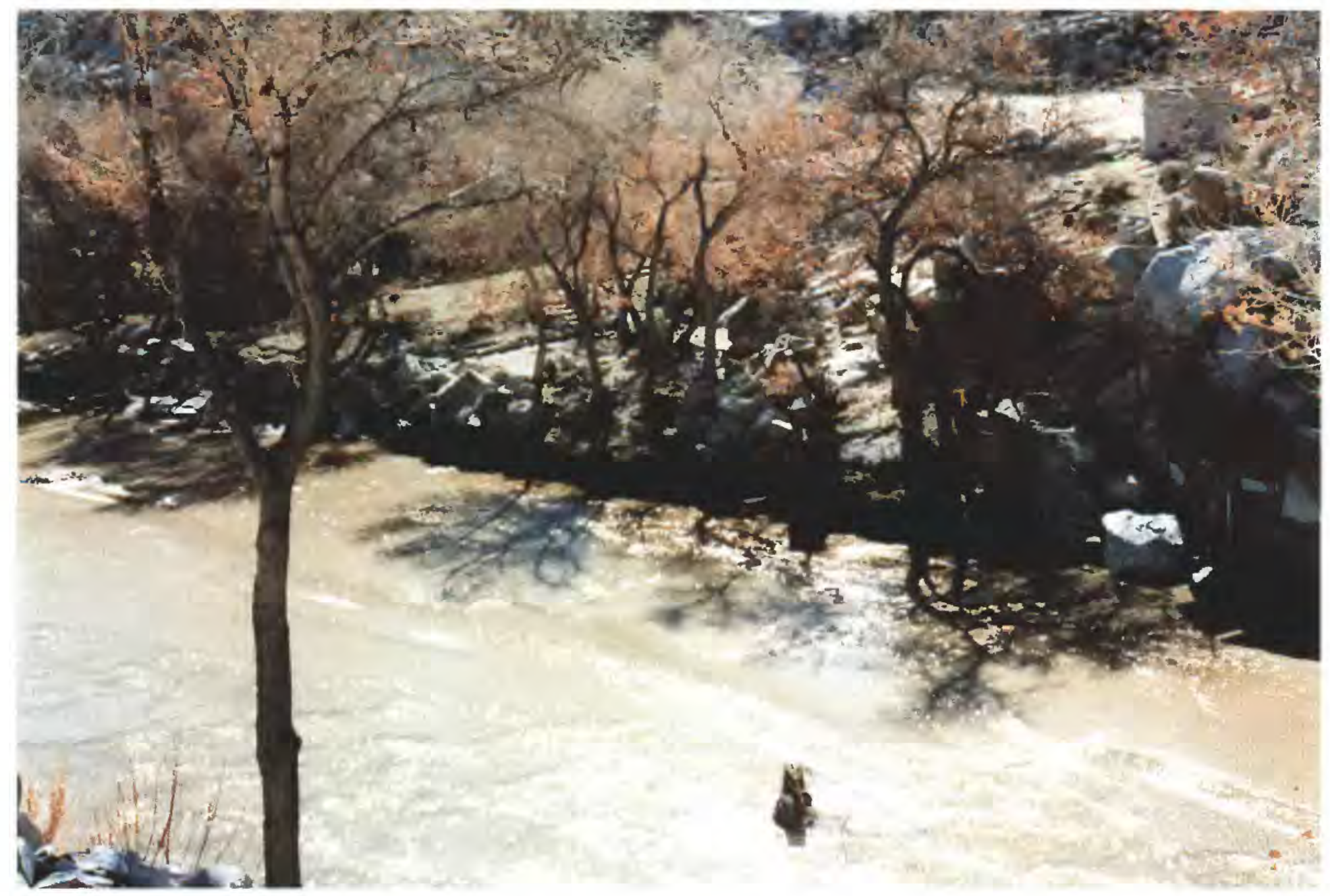

Figure 5. Gaging station 10261500, Mojave River at Lower Narrows, near Victorville, January 31, 1995. (Gage house in top right hand corner.) 
At the mouth of Afton Canyon at the lower end of the main stem, the Mojave River has been measured at station 10263000 (fig. 7) periodically since water year 1930. The station was operated during water years 1930-32, and it was reactivated in water year 1953. Records for water years 1979 and 1980 are incomplete, and only discharge measurements were published during these two years. Drainage area of the Mojave River at the station is $2,121 \mathrm{mi}^{2}$, which includes a total of about $520 \mathrm{mi}^{2}$ of noncontributing area (internal drainage in Apple Valley and to Troy Lake).

Mullen and others (1994) point out the following regarding accuracy of gaging-station records:

The accuracy of discharge data depends primarily on (1) the stability of the stage-discharge relation or, if the control is unstable, the frequency of discharge measurements, and (2) the accuracy of observations of stage, measurements of discharge, and interpretations of records.
For gaging stations on Deep Creek, West Fork, and the main stem of the Mojave River, the daily mean discharges generally have been rated as "fair" or "poor," "Fair" means that about 95 percent of the computed daily mean discharges are within 15 percent of the true daily mean discharge. "Poor" means that daily mean discharges have less than "fair" accuracy.

According to Robert W. Meyer (U.S. Geological Survey, written commun., 1995), an analysis of gaging-station records indicates that uncertainty of daily mean discharges at the Deep Creek gage (10260500) ranges from about 5 to 35 percent and averages about 20 percent. Similarly, uncertainty of daily mean discharges at West Fork gaging stations (10260950 and 10261000) ranges from about 5 to 35 percent and averages about 15 percent. Daily mean discharges at the Lower Narrows gaging station (10261500) have an uncertainty that ranges from about 5 to 70 percent and averages about 15 percent. Meyer's analysis is based on a split-sample method developed by Dawdy and Burkham (1970), which can

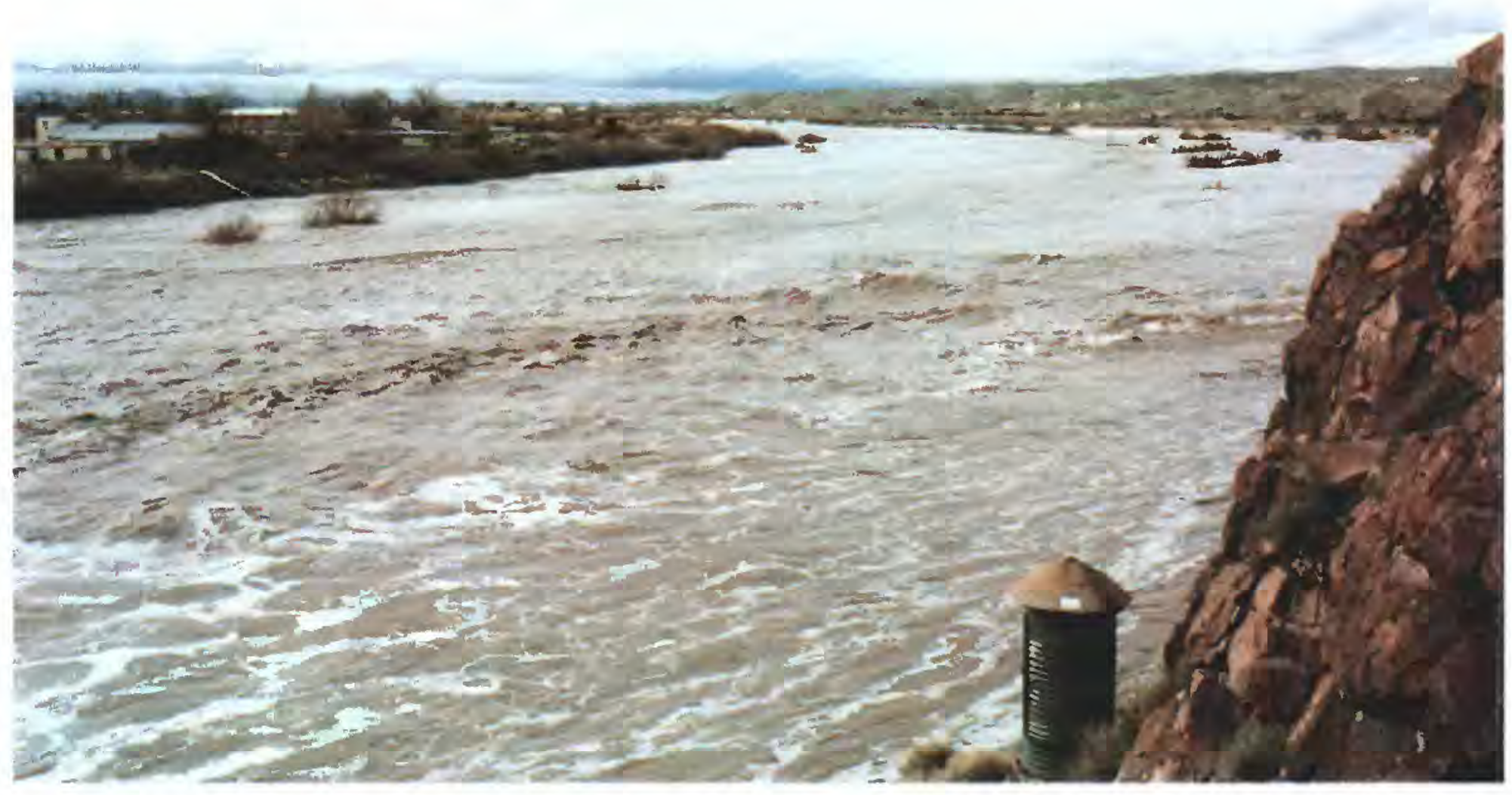

Figure 6. Gaging station 10262500, Mojave River at Barstow, January 18, 1993. (Discharge about 4,200 cubic feet per second.) 
be applied to stations that have a large number of discharge measurements. Although too few measurements were available to apply the method to records at Barstow (10262500) and at Afton Canyon (10263000), Meyer estimates that uncertainty at these two stations probably ranges from 5 to 20 percent, but it could be as high as 50 percent during some days having no gage-height record because of instrument malfunction.

The following discussion in this report will concentrate on water years 1931-94. Although there are some breaks in the gaging-station record on West Fork and the Mojave River at Afton Canyon during this 64-year period, continuous record exists since water year 1931 for stations on Deep Creek, Mojave River at Lower Narrows, and Mojave River at Barstow.

\section{Streamflow from Headwaters}

Deep Creek at The Forks is a perennial stream. During the period of record at gaging station 10260500, Deep Creek ceased to flow during only two days (July 17 and 18, 1961). West Fork Mojave River, however, is an ephemeral stream at The Forks. West Fork flows only in response to storm runoff and releases from Silverwood Lake.

Flow-duration curves are shown in figure 8 for both Deep Creek and West Fork prior to and after completion of Cedar Springs Dam on Silverwood Lake in 1971. The curves show the percentage of time that specified stream discharges were equaled or exceeded at the gaging stations (Searcy, 1959). For example, the two curves for West Fork show that prior to construction of Cedar Springs Dam, the discharge (during 1931-71) exceeded $0.1 \mathrm{ft}^{3} / \mathrm{s}$ about 37 percent of the time; after completion of the dam, discharge

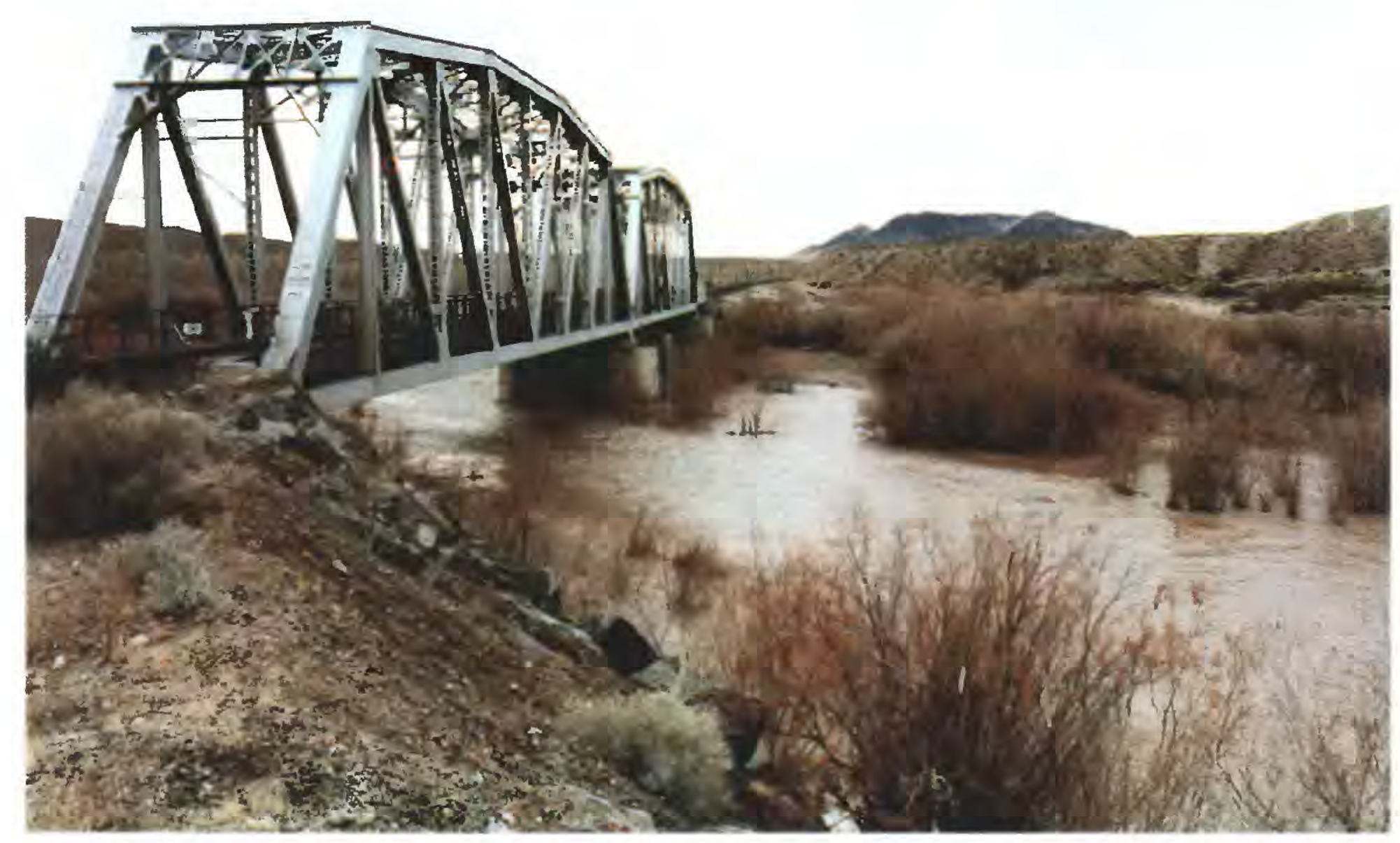

Figure 7. Gaging station 10263000, Mojave River at Afton, January 17, 1993. 
exceeded $0.1 \mathrm{ft}^{3} / \mathrm{s}$ about 44 percent of time. In fact, the duration of flow was longer for the complete range of discharge after completion of the dam. Deep Creek, which is not regulated by Silverwood Lake, had a similar increase in flow duration after 1971.

The combined annual discharge of Deep Creek and West Fork at The Forks during water years 193194 is shown in figure 9. This annual inflow to the main stem of the Mojave River averaged about 71,000 acre-ft (about 47,000 acre-ft from Deep Creek and 24,000 acre-ft from West Fork). The smallest annual inflow (2,200 acre-ft) occurred during water year 1951 when West Fork did not flow the entire year. The five largest annual inflows occurred after 1968, and the largest (about 430,000 acre-ft) occurred during water year 1993. It should be noted that water years 197274 are queried in figure 9 because no gaging station was in operation on West Fork during these three years, and discharge at gaging station 10261100 below Mojave River Forks Reservoir was used to estimate inflow to the main stem.

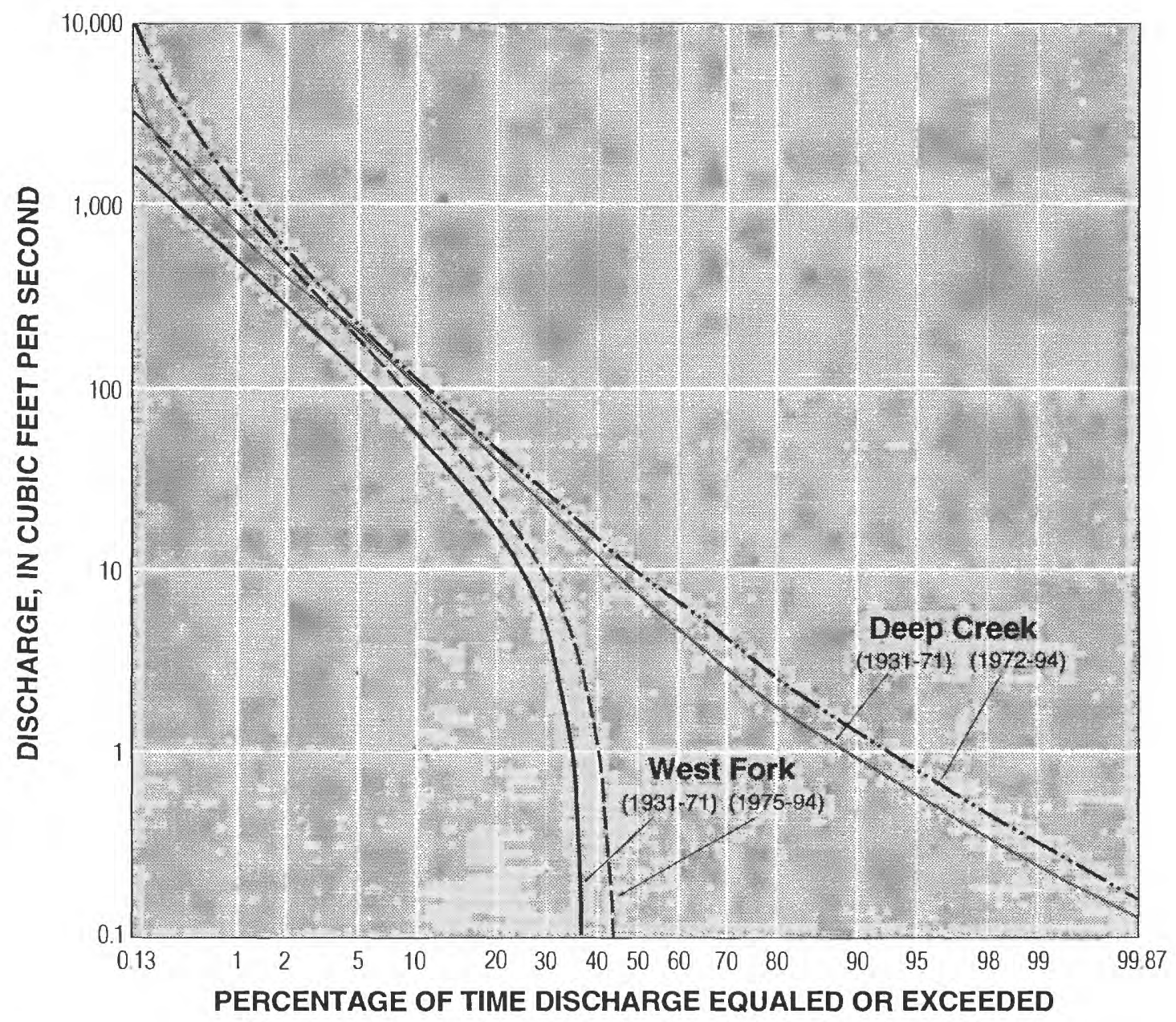

Figure 8. Flow duration for Deep Creek at gaging station 10260500 (water years 1931-71 and 1972-94) and for West Fork Mojave River at gaging stations 10261000 and 10260950 (water years $1931-71$ and 1975-94). 
Over a long period of time (water years 193194), runoff per unit area has been similar in the two headwaters basins. Annual runoff averaged 6.6 in. for the Deep Creek basin and 6.3 in. for the West Fork drainage basin.

The probability of a given inflow to the main stem being exceeded in any given water year is shown in figure 10. For example, there is a 90 -percent probability that the combined annual runoff from Deep Creek and West Fork will exceed 10,000 acre-ft in any given year, a 50-percent probability that it will exceed 40,000 acre-ft, and about a 2-percent probability that it will exceed 400,000 acre-ft. Recurrence intervals also are shown in figure 10. A recurrence interval is simply the reciprocal of the exceedance probability when expressed as a decimal fraction. Thus, an exceedance probability of 0.20 (20 percent)

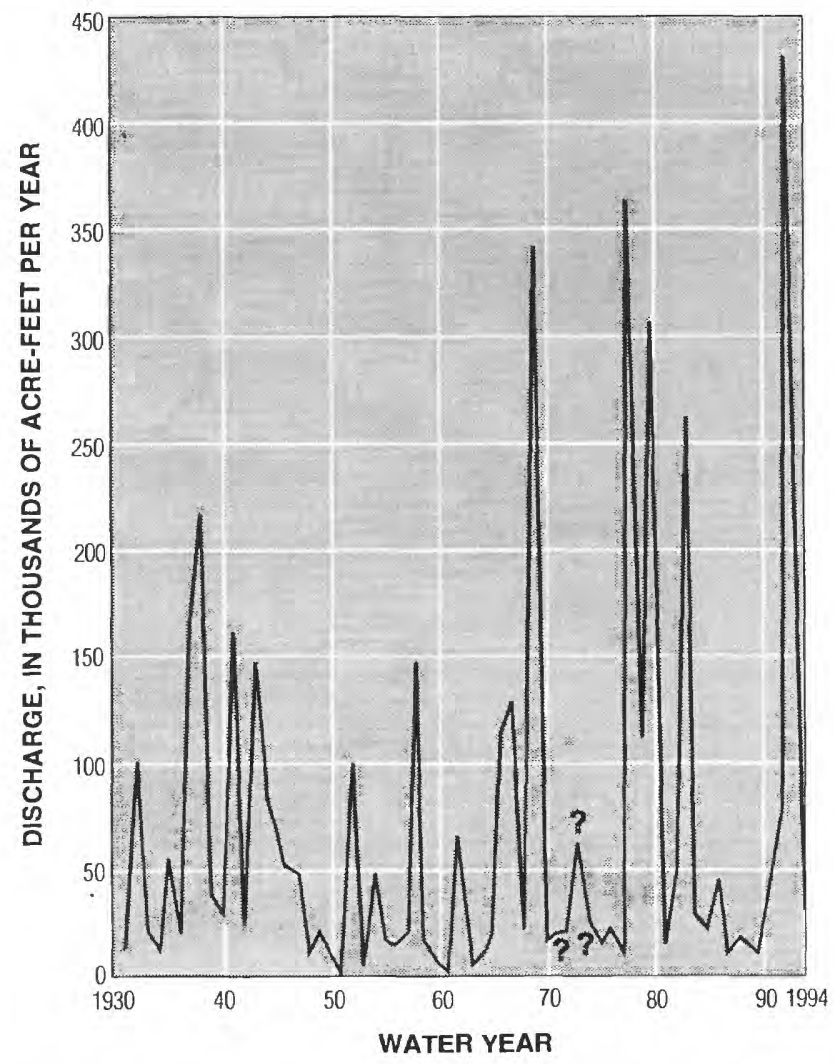

Figure 9. Total annual inflow to main stem of Mojave River from the headwaters, water years 1931-94. (Based on the combined annual runoff of Deep Creek and West Fork Mojave River.) is equivalent to a recurrence interval of 5 years. From the graph, we see that an annual inflow of about 100,000 acre-ft or greater will occur, on the average, once every 5 years (recurrence interval).

Selected water years are labeled in figure 10 to identify years at both the low and high extremes and the years during and immediately preceding this study. Here again, it is apparent that the 5 largest annual inflows to the main stem occurred after 1968. Five of the six lowest annual inflows occurred during the 1950 's and 1960's. Water years 1992-94, the period of field work for this study, include the year with the

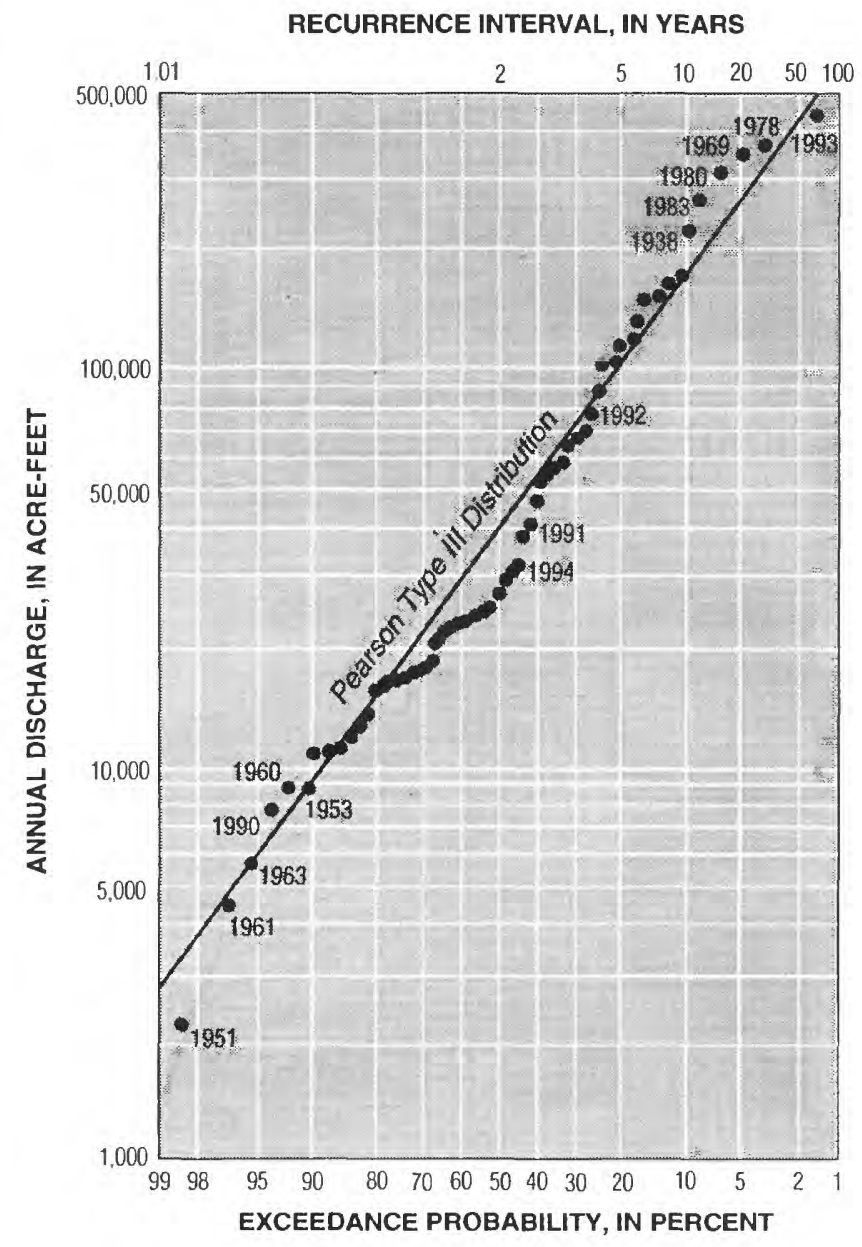

Figure 10. Exceedance probabilities and recurrence intervals for total annual inflow to main stem of Mojave River from the headwaters. (Based on the combined annual runoff of Deep Creek and West Fork Mojave River, water years 1931-94; selected water years identified.) 
highest inflow of record (1993) and two years with slightly "above average" inflow.

\section{Streamflow Along Main Stem}

Most of the water entering the main stem of the Mojave River from the headwaters is lost by infiltration into the permeable streambed. As pointed out in the previous section, annual inflow from the headwaters averaged about 71,000 acre-ft during water years 1931-94. Whereas, during this same period, annual flow averaged about 54,000 acre-ft at the gaging station near Victorville (10261500) and about 18,000 acre- $\mathrm{ft}$ at the Barstow gaging station (10262500). The average annual flow at the gaging station in Afton Canyon (10263000) during water years 1931-32, 1953-78, and 1981-94 was about 7,500 acre-ft.

The mean daily discharges for the gaging stations near Victorville, at Barstow, and in Afton Canyon are shown in figures 11-13. The perennial nature of the Mojave River near Victorville is apparent from its hydrograph (fig. 11), as is the annual cycle of wintertime high discharges and summertime low discharges. The low discharges in the annual cycle are caused by streamflow depletion by ground-water pumping and evapotranspiration, which is discussed in detail in a later section of this report. Superimposed on the annual cycle are periods of storm runoff, which commonly occur during January-March. The ephemeral nature of the river at Barstow is apparent from its hydrograph (fig. 12). The number of days of no flow at Barstow far exceed the number of days with

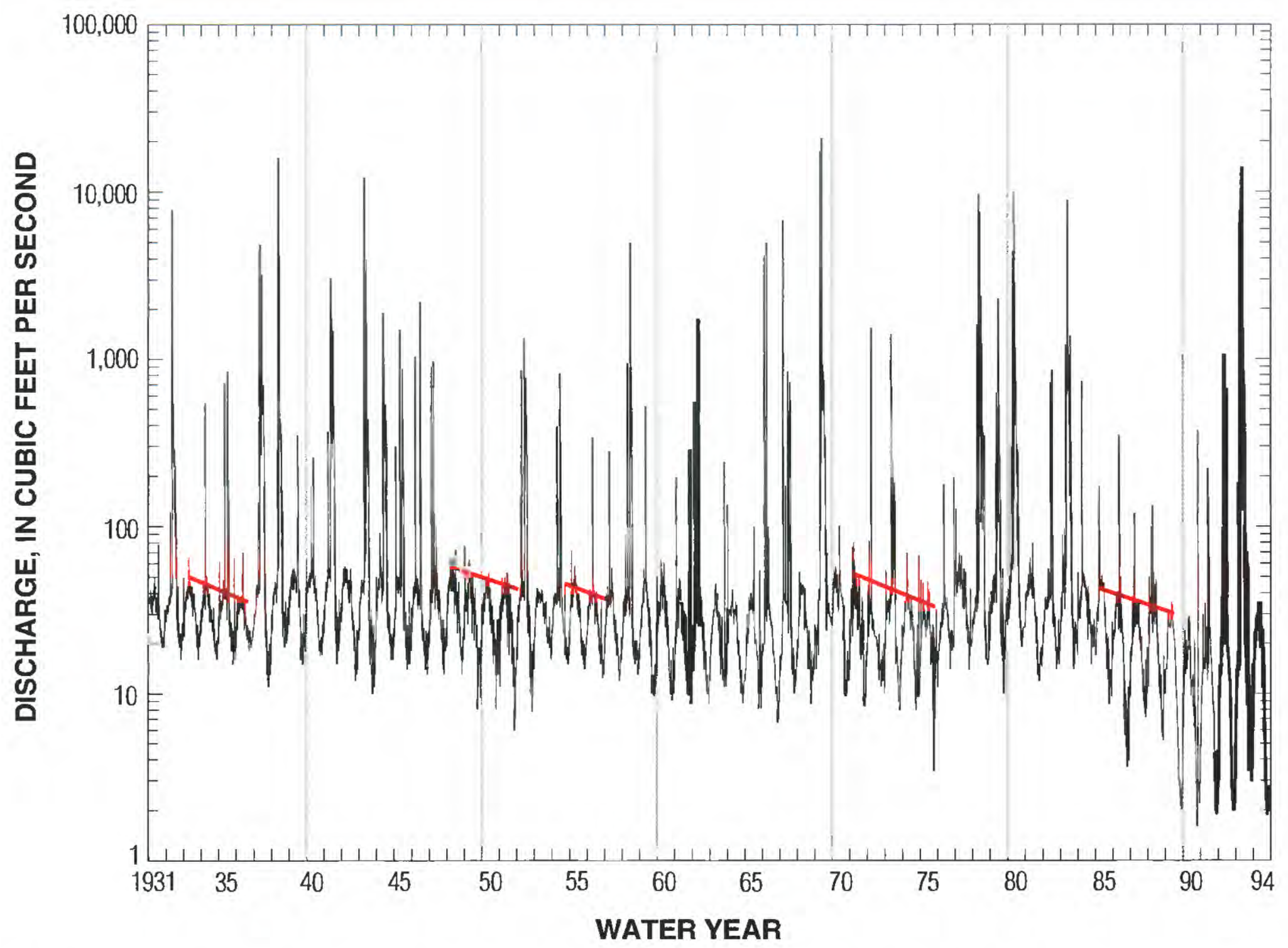

Figure 11. Daily mean discharge at gaging station 10261500 , Mojave River at Lower Narrows, near Victorville, water years 1931-94. (Recession index lines shown in red.) 
flow. The river at Barstow, at least since water year 1931, has flowed only in response to storm runoff.

Streamflow at Afton Canyon (fig. 13) has an annual cycle that is similar to that for flow near Victorville, except the summertime depletion in flow is due entirely to evapotranspiration. The river at Afton Canyon has ceased to flow several times, most recently during the summer of 1994.

It has been suggested that the regulation of streamflow in the headwaters by Silverwood Lake and Mojave River Forks Reservoir has markedly changed streamflow characteristics along the main stem of the Mojave River. Although both reservoirs undoubtedly have attenuated flood peaks, neither has had an effect on volumes of runoff entering the main stem. Flowduration curves for the periods of record prior to and following the completion of the reservoirs in water year 1971 are shown for gaging stations near Victorville, at Barstow, and at Afton Canyon (fig. 14). At all three stations, the duration of the largest discharges (greater than about 1,000 $\mathrm{ft}^{3} / \mathrm{s}$ ) increased after the completion of Silverwood Lake and Forks Reservoir. Conversely, at all three stations, the smaller discharges seem to have decreased in duration since 1971, mainly as a result of streamflow depletion by ground-water pumping. This is in contrast to increased duration of low flows after 1971 at gaging stations on Deep Creek and West Fork (fig. 8).

Reaches of the main stem of the Mojave River that had streamflow during water years 1992-94 are shown in blue in figure 15. River miles in figure 15 correspond to river miles shown on the map in figure

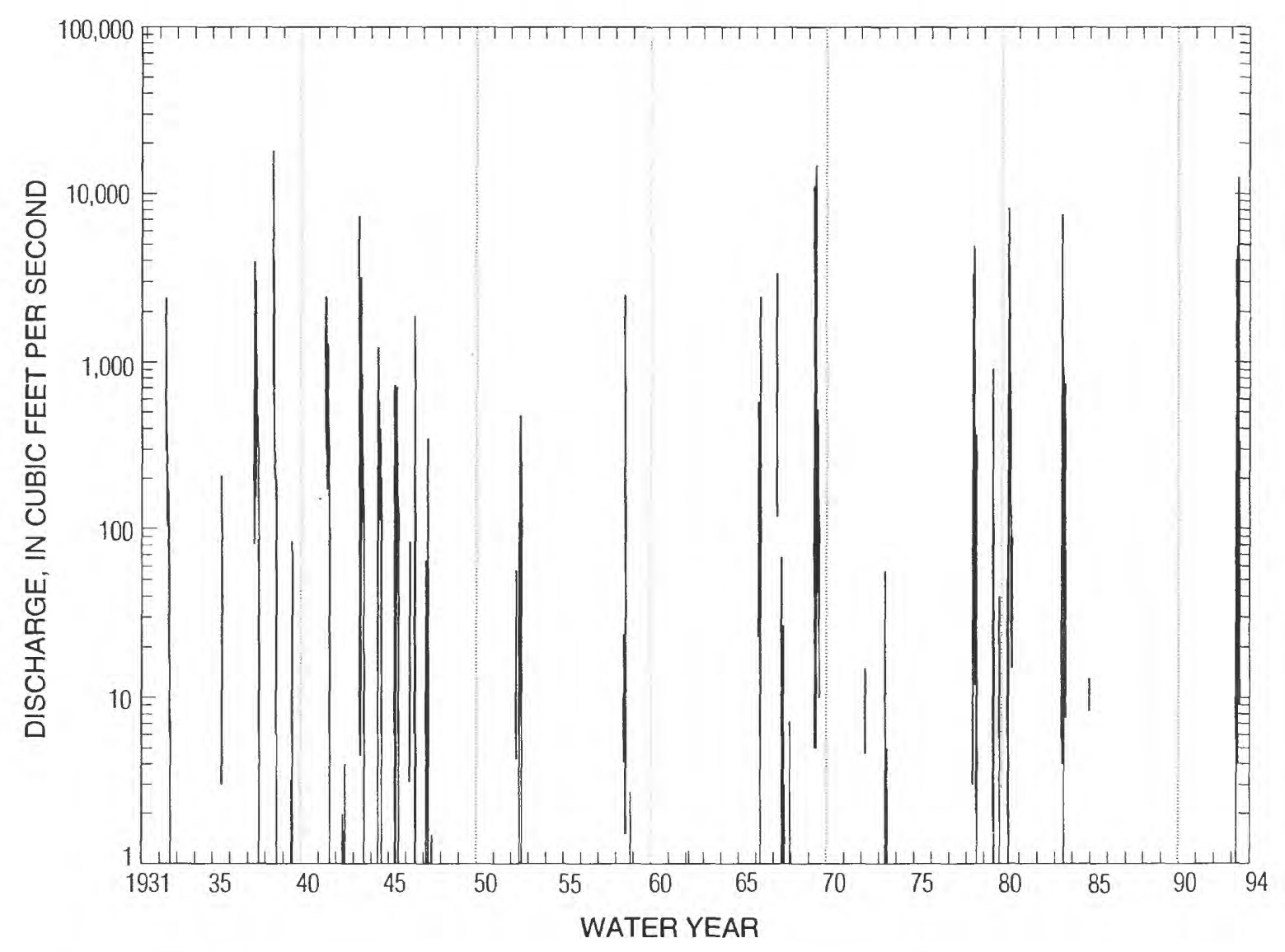

Figure 12. Daily mean discharge at gaging station 10262500, Mojave River at Barstow, water years 1931-94. 
4. As can be seen in figure 15 , most of the main stem of the Mojave River was dry during this 3-year period. The river flowed along the entire main stem for only a few weeks in the winter of water year 1993.

In non-storm periods during water years 199294, water from Deep Creek and West Fork emerged from the tunnel through the dam at Mojave River Forks Reservoir and flowed only a few miles before infiltrating in the sandy streambed of the Mojave River. At about miles 9 and 10, the river began to flow again with the discharge from two fish hatcheries (fig. 4). These and other manmade discharges to the river are discussed in greater detail in a later section of this report. During summer and fall of each year, water discharged from the fish hatcheries also rapidly infiltrated into the streambed. At about mile 12, because of thinning of the flood-plain aquifer, groundwater discharged naturally into the river. This discharge of ground water (base flow) continued through the Upper and Lower Narrows creating the perennial flow at gaging station 10261500 at the Lower Narrows.

Streamflow leaving the Lower Narrows and entering the middle section of the Mojave River main stem rapidly infiltrated into the flood-plain aquifer, and the river between about miles 18 and 22 was dry for long periods during water years 1993 and 1994. During water year 1992, this reach of the river had continuous flow, probably because of leakage from a sewage line beneath the river. (The sewage line was repaired in the spring of 1993.) At about mile 22, wastewater from the treatment facilities of Victor

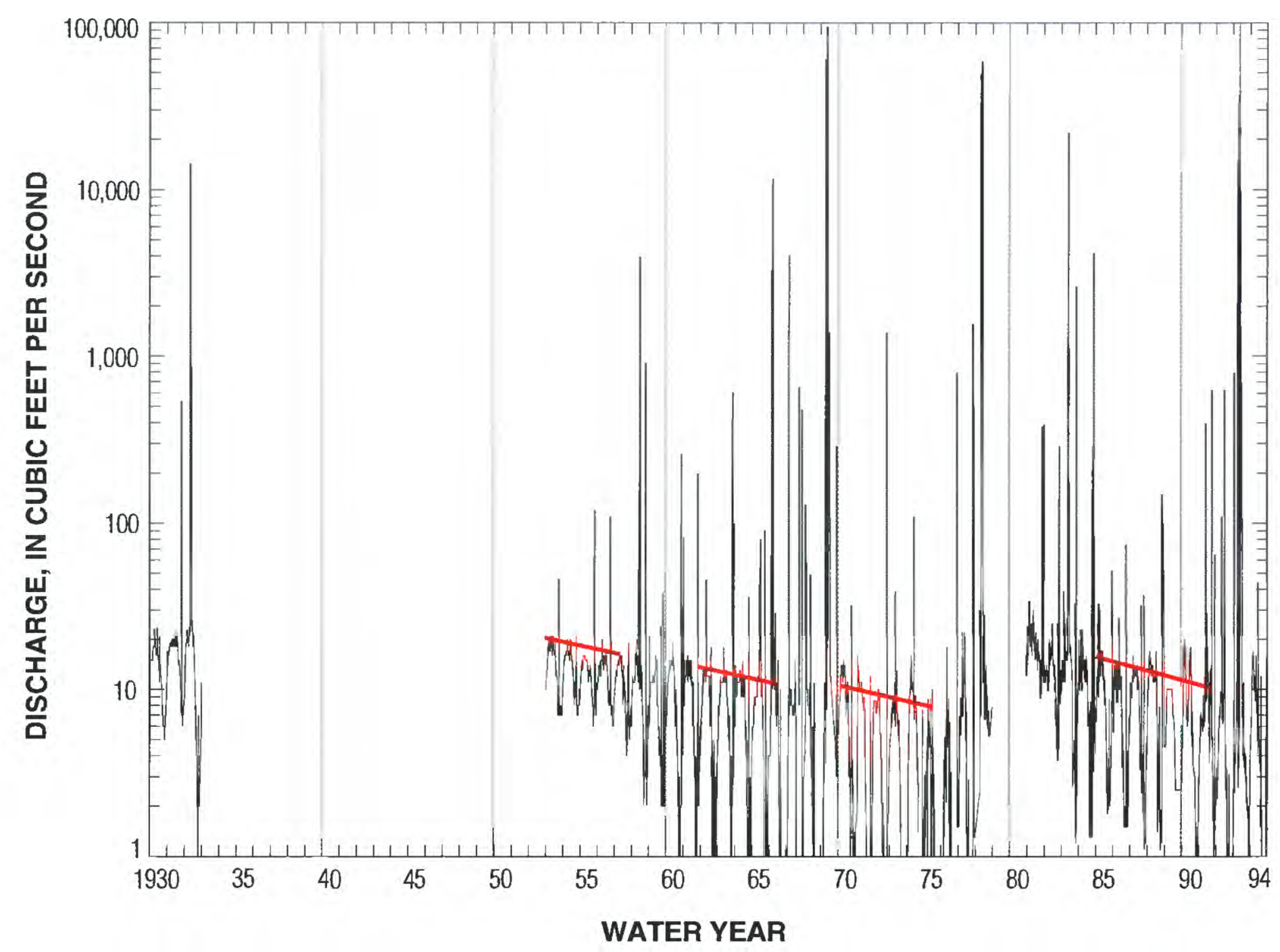

Figure 13. Daily mean discharge at gaging station 10263000 , Mojave River at Afton, water years 1930-32, 1953-78, and 1981-94. (Recession index lines shown in red.) 
Valley Wastewater Reclamation Authority was discharged into the river, creating a reach of perennial flow between river miles 22 and 26 (see fig. 15). The remainder of the middle main stem and most of the lower main stem were dry during water years 1992-94, except during periods of winter storm runoff primarily from the headwaters. Thinning of the flood-plain aquifer at Afton Canyon caused ground water to discharge into the river beginning about $1 \mathrm{mi}$ above gaging station 10263000 . The river flowed continuously at the gaging station in Afton Canyon except for a few days in the summers of water years 1992 and 1994.

The analysis of frequency and magnitude of annual runoff from the headwaters section (fig. 10) indicates that runoff in water year 1993 was the greatest during the period 1931-94 and that runoff in water years 1992 and 1994 also was above average (exceedance probabilities less than 50 percent). As shown in figure 15, the first peak of runoff from the headwaters during water year 1993 extended river flow to about river mile 32 (Helendale). The second

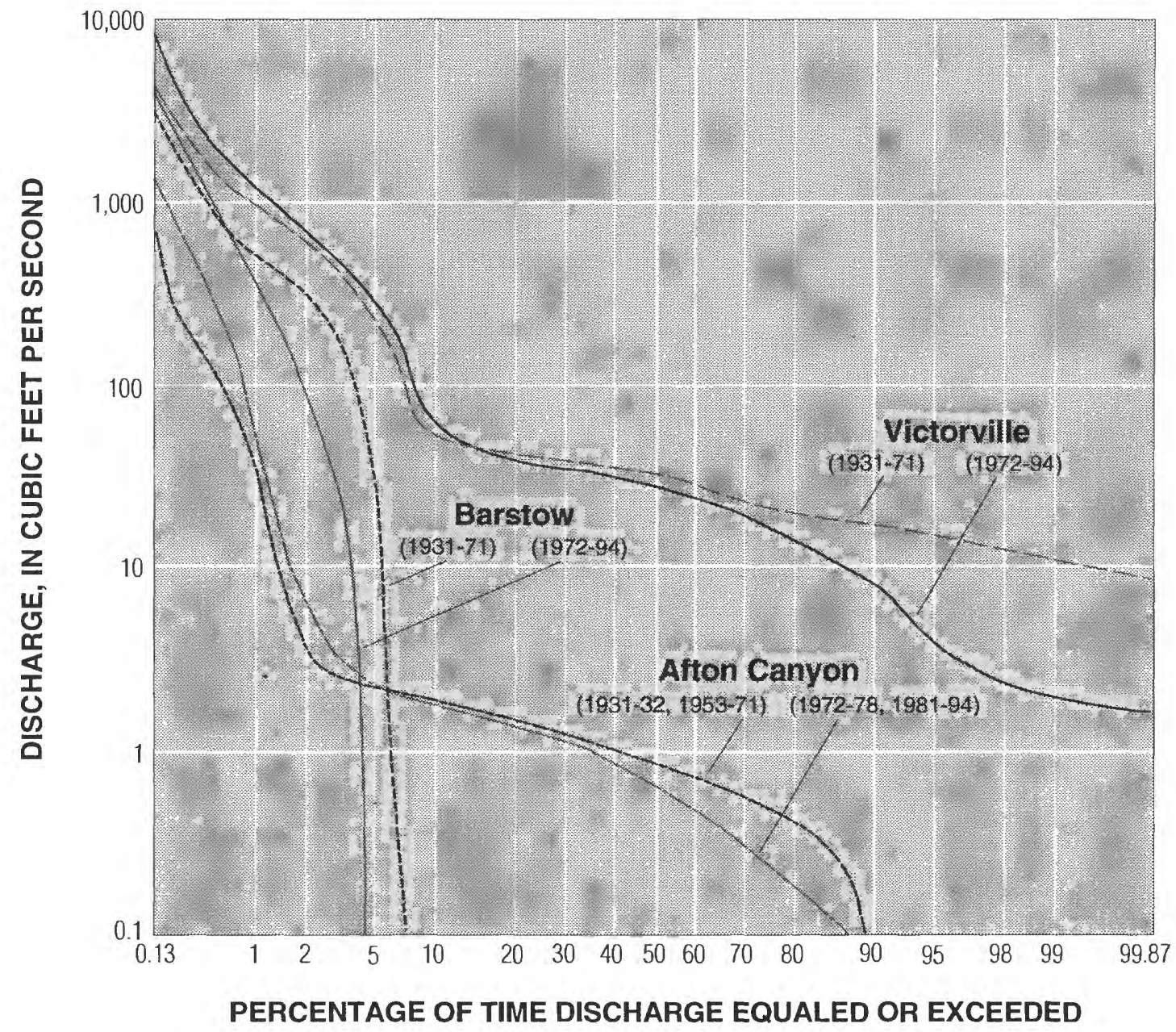

Figure 14. Flow duration for the Mojave River near Victorville (gaging station 10261500), at Barstow (gaging station 10262500), and at Afton Canyon (gaging station 10263000) during selected periods. 
peak extended river flow to about river mile 79 , about 3 mi upstream from Camp Cady. Because most of the streambed had been wetted, the third, fourth, and fifth peaks extended the river flow to Afton Canyon and beyond.

During water year 1992, wintertime runoff from the headwaters, coupled with wintertime decreases in ground-water pumping and evapotranspiration from the flood-plain aquifer, extended river flow to about river mile 45, which is about 2 mi upstream from Lenwood. But during 1994, a slightly-above-average year with headwaters inflow having an exceedance probability of about 45 percent, wintertime runoff from the headwaters completely infiltrated into the

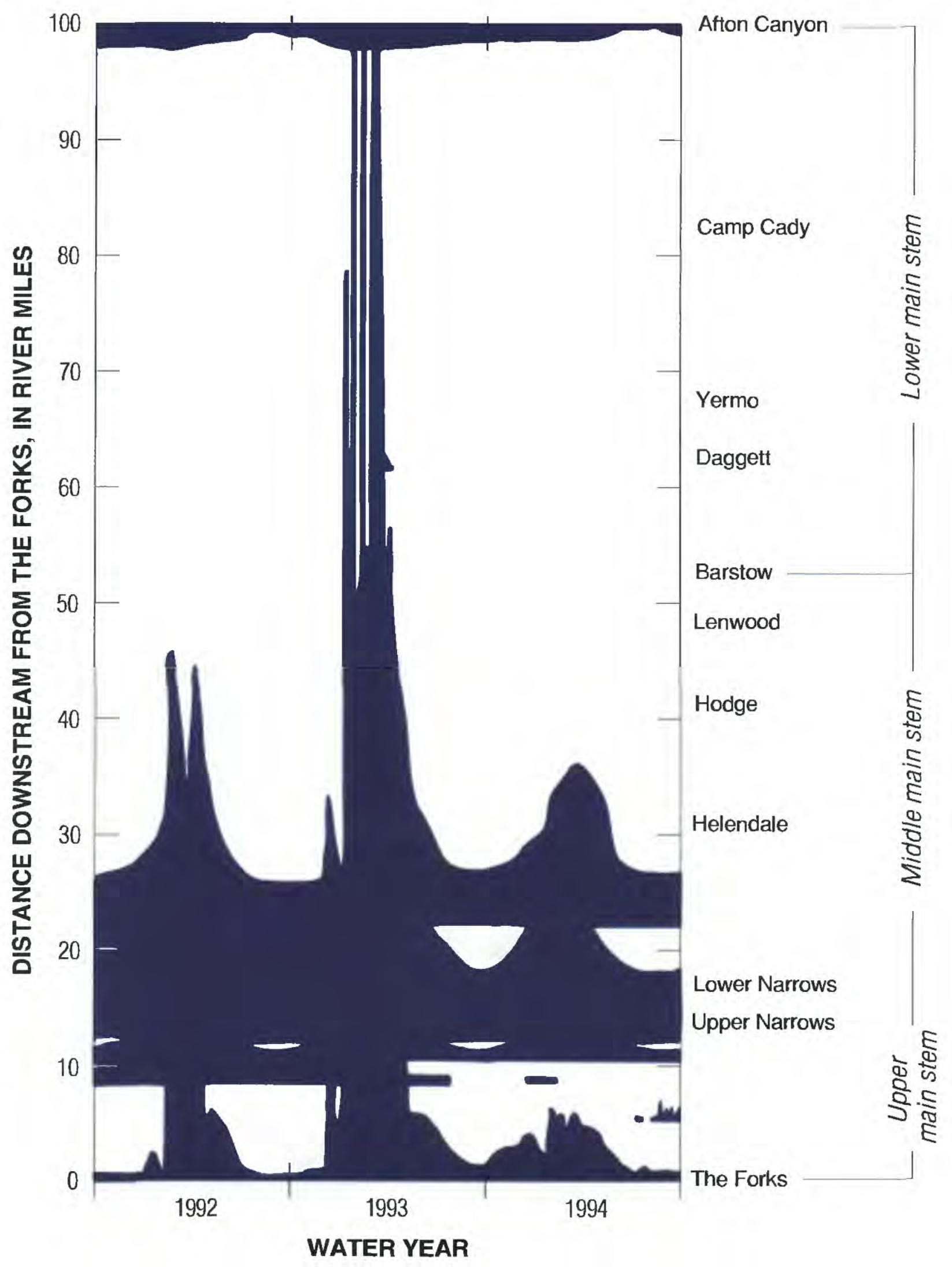

Figure 15. Reaches of the main stem of the Mojave River that had streamflow (blue areas) during water years 1992-94. 
streambed by about river mile 6 . The extension of flow to about river mile 36 during the winter of 1994 was again largely due to wintertime decreases in pumping and evapotranspiration, both of which are discussed in greater detail later in this report.

Descriptions of the Mojave River during the 18 th and 19th centuries are brief, but diaries, journals, and reports of early travelers and explorers provide some insight into streamflow conditions. The first written record is a diary by Father Francisco Garcés (1738-81), a Franciscan priest who travelled along the Mojave River in search of a route from the Colorado River to Monterey in Spanish California. The diary has been translated into English and interpreted by Coues (1900). On March 9, 1776, Garcés describes entering a canyon (Afton Canyon) having a stream of brackish water. Garcés continued his travel upstream along the Mojave River and camped at several places described by him as having abundant water and pasturage. Garcés described crossing the river somewhere near Hodge on March 16 and having to camp at the crossing for a day to dry cargo, carried by his mule, that had been soaked in crossing the river. Garcés encountered several Indian rancherias along reaches of the river having flow as he continued his travels through the Lower and Upper Narrows toward the headwaters.

Trappers and explorers - the most notable being Jedediah Smith (in 1826), Capt. John C. Fremont (in 1844), and Kit Carson (in 1848)-and thousands of pioneers traveled the Spanish Trail and Mormon Road along the Mojave River during the 1800 's. Along stretches of the river that had flowing water or a shallow water table, well-used camp sites were established. Camp Cady (an Army post occupied in 1863-64 at river mile 82), Fork of Roads (mile 70), Fish Pond (mile 60), Grapevine (mile 55), Cottonwoods (mile 40), Point of Rocks (mile 34), and Lane's Crossing (mile 20) became well-known watering and resting spots (Walker 1986, p. 190). Many of these sites, particularly those along the lower main stem of the river, no longer have year-round flow in the river (see fig. 15) or a shallow water table.

Other changes in the river can be ascertained by comparing current conditions with those observed during land surveys of the 1850 's. Ralph W. Norris' survey of the Helendale area in 1853 noter an extensive swamp area in sections 29,30 , and 31 , township 8 N., range $4 \mathrm{~W}$. During water years 1992 94, this reach (river miles 31 and 32) was dry most of the time (see fig. 15). Also, Henry Hancork's survey of the Victorville area in 1855 notes swamps in sections $23,24,25,26$, and 30 , township $5 \mathrm{~N}$., range 4 W. (river miles 10 to 12). Comparison of Hancock's detailed descriptions with conditions during water years 1992-94 indicates that the swamps no longer exist, although the river flows through this reach most of the year. Microfilm of original land-su-vey notes and maps are on file in the U.S. Bureau of Land Management office in Barstow, Californic.

\section{Ungaged Tributary Streams}

Before the gaging-station records cen be used to quantitatively evaluate ground-water and surfacewater relations, all accretions to (and losses from) streamflow between the stations must be lnown. Along the main stem of the Mojave River, these accretions include runoff from ungaged tributary streams and manmade discharges to the river. Any diversions from a stream also would have to be acconnted for; however, there have been no major divers'ins from the Mojave River main stem since the 19. T's.

An area of about $1,400 \mathrm{mi}^{2}$ contributes runoff to the main stem of the Mojave River between The Forks and Afton Canyon. Most of this runoff enters the river through ephemeral tributary streams that flow only in response to storm runoff. The runoff from tributary streams has been ungaged. For this study, channelgeometry techniques were used to estimate the mean annual flow of ephemeral tributary streams.

Channel-geometry techniques have been used by several researchers to estimate various streamflow characteristics in the Western United States. Hedman (1970) developed channel-geometry relations using a large number of streams in California, and the reader is referred to Hedman's report for discussions of the concepts and techniques. Because many of the streams in Hedman's study were in more tumid coastal areas or had larger drainage areas than most streams in the Mojave River basin, the author developed new 
relations between annual mean flow and channel geometry specifically for the Mojave Desert region.

Channel dimensions were measured at 29 active and discontinued gaging stations in the Mojave Desert region, including several along the Mojave River. These 29 gaging stations are listed in table 1 along with drainage area, period of record, annual mern discharge, and average channel width. When

Table 1. Annual mean discharge and channel width at 29 gaging stations in the Mojave Desert region $\left[\mathrm{mi}^{2}\right.$, square mile; acre-ft, acre-foot; $\mathrm{ft}$, foot]

\begin{tabular}{|c|c|c|c|c|c|}
\hline Station no. & Station name & $\begin{array}{c}\text { Drainage } \\
\text { area } \\
\left(\mathrm{mi}^{2}\right)\end{array}$ & $\begin{array}{c}\text { Period of } \\
\text { record } \\
\text { (water years) }\end{array}$ & $\begin{array}{c}\text { Annual } \\
\text { mean } \\
\text { discharge } \\
\text { (acre-ft) }\end{array}$ & $\begin{array}{c}\text { Avarage } \\
\text { channel } \\
\text { width } \\
\text { (ft) }\end{array}$ \\
\hline 10252550 & Caruthers Creek near Ivanpah & 1.13 & $\begin{array}{l}1964-81 \\
1983-93\end{array}$ & 94 & 1.6 \\
\hline 10255700 & San Felipe Creek near Julian & 89.2 & $1959-83$ & 710 & 4.5 \\
\hline 10255805 & Coyote Creek below Box Canyon, near Borrego Springs & 154 & $1951-93$ & 1,930 & 4.4 \\
\hline 10255810 & Borrego Palm Creek near Borrego Springs & 21.8 & 1951-93 & 750 & 3.1 \\
\hline 10256000 & Whitewater River at White Water & 57.5 & 1949-79 & 12,600 & 8.3 \\
\hline 10257720 & Chino Canyon Creek below tramway, near Palm Springs & 4.70 & $1987-93$ & 658 & 2.9 \\
\hline 10258000 & Tahquitz Creek near Palm Springs & 16.9 & $\begin{array}{l}1948-82 \\
1984-93\end{array}$ & 3,880 & 11 \\
\hline 10258500 & Palm Canyon Creek near Palm Springs & 93.1 & $\begin{array}{l}1931-41 \\
1948-93\end{array}$ & 3,960 & 3.0 \\
\hline 10259000 & Andreas Creek near Palm Springs & 8.65 & $1949-93$ & 2,220 & 4.9 \\
\hline 10260400 & Cushenbury Creek near Lucern Valley & 6.36 & $1958-71$ & 46 & 3.6 \\
\hline 10260500 & Deep Creek near Hesperia & 134 & $\begin{array}{l}1905-22 \\
1930-93\end{array}$ & 52,700 & 38 \\
\hline 10260620 & Houston Creek above Lake Gregory,at Crestline & 35 & $1980-93$ & 518 & 1.3 \\
\hline 10260630 & Abondigas Creek above Lake Gregory, at Crestline & 1.15 & $1980-93$ & 878 & 3.9 \\
\hline 10260950 & $\begin{array}{l}\text { West Fork Mojave River above Mojave River Forks Reservoir, } \\
\text { near Hesperia }\end{array}$ & 70.3 & $1975-93$ & 33,140 & 13 \\
\hline 10261100 & $\begin{array}{l}\text { Mojave River below Mojave River Forks Reservoir, near } \\
\text { Hesperia }\end{array}$ & 211 & $\begin{array}{l}1972-74 \\
1981-93\end{array}$ & 45,920 & 35 \\
\hline 10261500 & Mojave River at Lower Narrows, near Victorville & 513 & $\begin{array}{l}1900-06 \\
1931-93\end{array}$ & 56,700 & 23 \\
\hline 10261800 & Beacon Creek at Helendale & 72 & $1961-67$ & .7 & 1.0 \\
\hline 10262500 & Mojave River at Barstow & 1,291 & $1931-93$ & 18,190 & 19 \\
\hline 10263000 & Mojave River at Afton & 2,121 & $\begin{array}{l}\text { 1930-32, } \\
1953-78 \\
1981-93\end{array}$ & 5,730 & 5.6 \\
\hline 10263500 & Big Rock Creek near Valyermo & 22.9 & $1924-93$ & 13,040 & 11 \\
\hline 10264560 & Spencer Canyon Creek near Fairmont & 3.68 & $1965-73$ & 38 & 1.8 \\
\hline 10264590 & Cottonwood Creek near Rosamond & 35.7 & $1966-72$ & 10 & 1.8 \\
\hline 10264600 & Oak Creek near Mojave & 15.8 & $1958-86$ & 920 & 2.9 \\
\hline 10264710 & Goler Gulch near Randsburg & 41.3 & $1967-72$ & 14 & 1.1 \\
\hline 10264740 & Cache Creek near Mojave & 96.5 & $1966-72$ & 87 & 4.0 \\
\hline 10264750 & Pine Tree Creek near Mojave & 33.5 & 1959-79 & 188 & 2.8 \\
\hline 10264770 & Cottonwood Creek near Cantil & 163 & $1967-72$ & 46 & 1.1 \\
\hline 10264878 & Ninemile Creek near Brown & 10.4 & $1962-71$ & 500 & 1.2 \\
\hline 11031500 & Agua Caliente Creek near Warner Springs & 19.0 & 1962-87 & 1,960 & 3.9 \\
\hline
\end{tabular}


determining channel dimensions, the channels were examined along reaches of 500 to $1,000 \mathrm{ft}$ to determine if consistent channel sizes were being formed. The width between the streamward shoulders of berms and bars was measured as the channel width (see fig. 16). In most cases, a carpenter's ruler was laid across the shoulders of the bars or berms that formed the channel, and the depth of this reference level down to channel bottom was measured as channel depth. The measurements were made across one to four sections and then averaged.

Multiple regression was used to determine the relation between annual mean discharge and channel width and depth at the gaging stations. As with most hydrologic relations, a logarithmic transformation of the data was necessary to linearize the relation. The regression analysis indicated that channel depth was not a statistically significant variable (at the 95 percent level, student $t$ was less then 1.95), and it was omitted from further regression analysis. The logarithmic transformation of the annual mean discharge and channel width at the 29 gaging stations, and the regression equation used to estimate annual mean discharge at ungaged sites, in the Mojave River basin is shown in figure 17 . The $\mathrm{R}^{2}$ (coefficient of determination) for this equation was 0.73 , and the

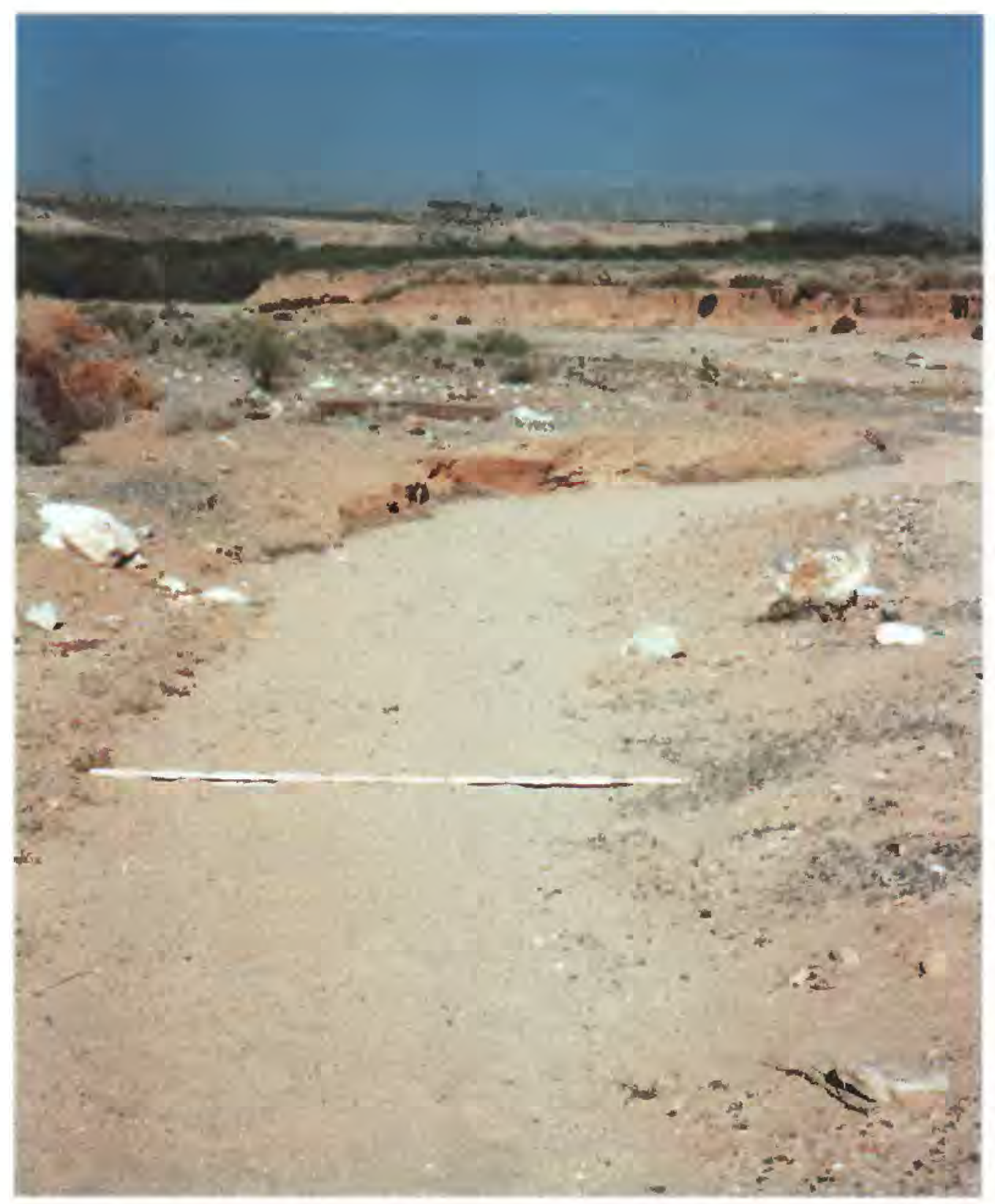

Figure 16. Channel-geometry measurement at site 10 on Bell Mountain Wash. (Channel width at this section was about 4.5 feet. Wooded Mojave River flood plain in background.) 
correlation coefficient was 0.86 . An examination of residuals indicates that they are randomly scattered along the regression line.

Channel dimensions also were measured at 22 sites on ungaged ephemeral streams tributary to the Mojave River. The sites are listed in table 2 along with drainage area, average channel width, the estimated annual mean discharge, and estimated runoff. Both annual mean discharge and runoff are rounded to one significant figure. The tributary streams were measured as close to their mouths as possible so that estimated discharge would represent accretion to flow of the Mojave River. The location of the 22 channel-geometry sites is shown in figure 4 .
Estimated annual runoff ranged from less than 0.001 to 2 in., although runoff from most sites ranged from 0.1 to $0.5 \mathrm{in.}$ In general, the runoff estimates were smaller for streams draining relatively flat terrain and larger for streams draining steep and rocky te rain. Drainage areas of the 22 sites include $125 \mathrm{mi}^{2}$ of the approximately $180-\mathrm{mi}^{2}$ area that drains into the $\mathrm{r}$-oper main stem of the Mojave River (excluding the headwaters), $557 \mathrm{mi}^{2}$ of the approximately $778-\mathrm{mi}^{2}$ area that drains into the middle main stem, and 180 $\mathrm{mi}^{2}$ of the approximately $432-\mathrm{mi}^{2}$ area that drainc into the lower main stem. On the basis of a drainage-areaweighted average annual runoff (in.) for each sertion of the main stem, estimated ungaged tributary inflow

Table 2. Channel width and estimated annual mean discharge and runoff in selected ephemeral tributary str?ams to the Mojave River

[mi ${ }^{2}$, square mile; acre-ft, acre-foot; $\mathrm{ft}$, foot; in., inch; <, less than]

\begin{tabular}{|c|c|c|c|c|c|}
\hline $\begin{array}{c}\text { Site No. } \\
\text { (fig. 4) }\end{array}$ & Stream name and location & $\begin{array}{c}\text { Drainage } \\
\text { area } \\
\left(\mathrm{mi}^{2}\right)\end{array}$ & $\begin{array}{c}\text { Average } \\
\text { channel } \\
\text { width } \\
(\mathrm{ft})\end{array}$ & $\begin{array}{l}\text { Estimated } \\
\text { annual } \\
\text { mean } \\
\text { discharge } \\
\text { (acre-ft) }\end{array}$ & $\begin{array}{l}\text { Estimated } \\
\text { runoff } \\
\text { (ir.) }\end{array}$ \\
\hline 1 & Unnamed, SW1/4 NW1/4 sec.18, T.3N., R.3W. & 1.2 & 1.0 & 30 & 0.5 \\
\hline 2 & Unnamed, NE1/4 SW1/4 sec.6, T.3N., R,3W. & 1.3 & 0.9 & 20 & .3 \\
\hline 3 & Unnamed, SE1/4 SW1/4 sec.36, T.4N., R.4W. & 7.5 & 1.3 & 50 & .1 \\
\hline 4 & Antelope Valley, SE1/4 NW1/4 sec.25, T.4N., R.4W. & 16.1 & 3.0 & 400 & .5 \\
\hline 5 & Unnamed, SW1/4 SE1/4 sec.12, T.4N., R4W. & 5.6 & 1.5 & 70 & .2 \\
\hline 6 & Unnamed, NW1/4 NW1/4 sec.12, T.4N., R4W. & 15.6 & 1.4 & 60 & .07 \\
\hline 7 & Unnamed, SE1/4 SE1/4 sec.7, T.4N., R.3W. & 7.5 & $<.1$ & $<.1$ & $<.071$ \\
\hline 8 & Desert Knolls Wash, SW1/4 SE1/4 sec.10, T.5N., R.4W. & 7.6 & 2.2 & 200 & .5 \\
\hline 9 & Oro Grande Wash, NE1/4 SW1/4 sec.10, T.5N., R.4W. & 27.8 & 1.2 & 40 & .03 \\
\hline 10 & Bell Mountain Wash, SW1/4 NW1/4 sec.34, T.6W., R.4W. & 34.9 & 4.2 & 800 & .4 \\
\hline 11 & Unnamed, SE1/4 SE1/4 sec.30, T.6N., R.4W. & 7.6 & 1.7 & 100 & .2 \\
\hline 12 & Fremont Wash, NE1/4 NE1/4 sec.2, T.7N., R.5W. & 254 & .8 & 20 & .071 \\
\hline 13 & Buckthorn Wash, NE1/4 SE1/4 sec.25, T.8N., R5W. & 104 & 2.9 & 300 & .05 \\
\hline 14 & Wild Wash, SE1/4 SE1/4 sec.7, T.8N., R.3W. & 47.7 & 2.8 & 300 & .1 \\
\hline 15 & Unnamed, NE1/4 SW1/4 sec.28, T.9N., R.3W. & 1.9 & 2.5 & 200 & 2 \\
\hline 16 & Stoddard Wash, SW1/4 SE1/4 sec.18, T.9N., R2W. & 142 & 4.2 & 800 & .1 \\
\hline 17 & Boom Creek, SW1/4 NE1/4 sec.11, T.9N., R.1W. & 1.6 & 1.8 & 100 & 1 \\
\hline 18 & Daggett Wash SE1/4 SW1/4 sec.17, T.9N., R.1E. & 24.0 & 3.0 & 400 & .3 \\
\hline 19 & Calico Wash, NE1/4 NE1/4 sec.6, T.9N., R.2E. & 100 & 3.2 & 400 & $.0^{n}$ \\
\hline 20 & Manix Wash, SE1/4 NE1/4 sec.10 T.10N., R.4E. & 45.2 & 3.3 & 500 & .2 \\
\hline 21 & Wilhelm Wash, SE1/4 NE1/4 sec.32, T.11N., R.5E. & 7.6 & 2.2 & 200 & .5 \\
\hline 22 & Unnamed, SW1/4 SE1/4 sec.18, T.11N., R.6E. & 1.6 & 1.0 & 30 & .4 \\
\hline
\end{tabular}


averaged about 2,400 acre-ft along the upper main stem, 2,400 acre-ft along the middle main stem, and 3,900 acre- $f t$ along the lower main stem. In comparison, annual inflow from the headwaters averaged about 71,000 acre-ft during water years 1931-94.

It is not possible to determine when the runoff from ungaged tributaries occurred in the past. But, if one assumes that the runoff in the ephemeral tributary streams occurred at the same relative magnitude as the ephemeral runoff in the Mojave River at Barstow (gaging station 10262500), the distribution of runoff would be that shown in figure 18 . For example, during

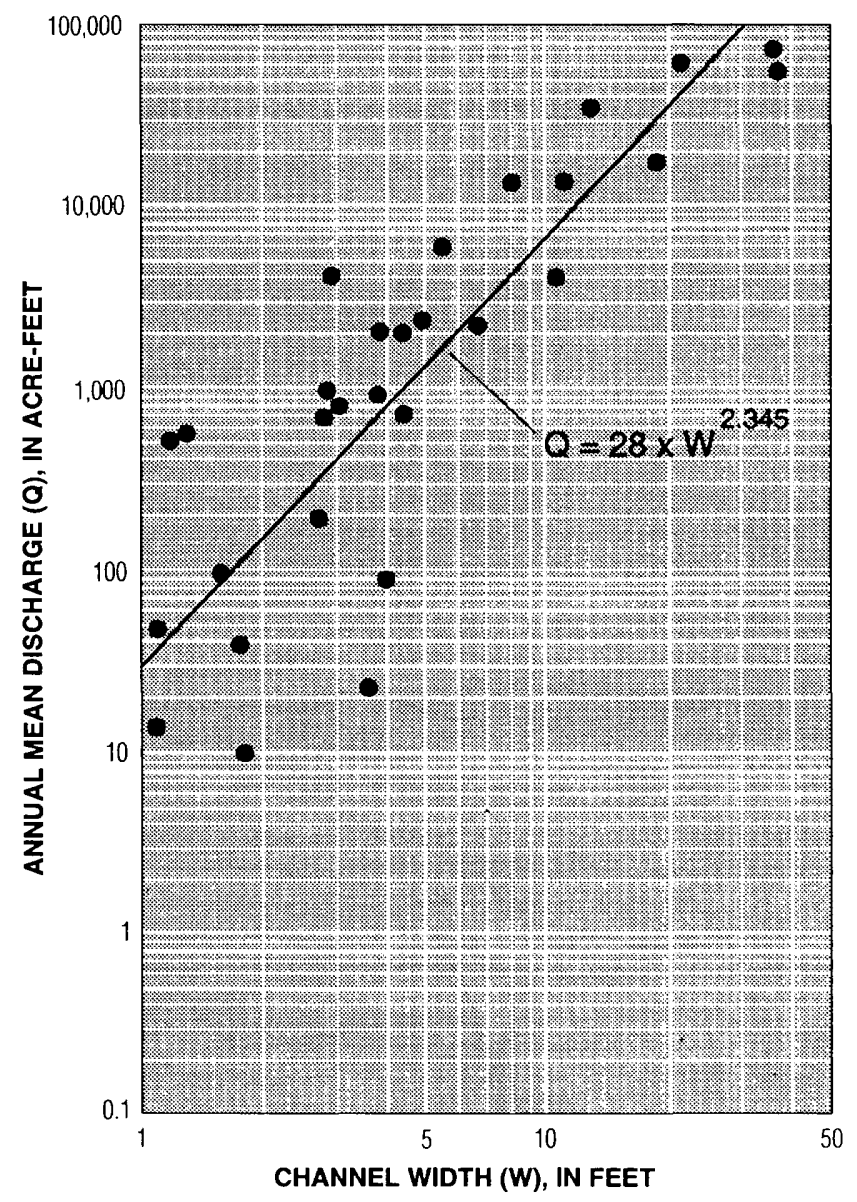

Figure 17 Relation between channel width and annual mean discharge at 29 gaging stations in Mojave Desert region. water year 1969 the annual discharge of the Mojave River at Barstow was about 820 percent of the average discharge. Assuming that ungaged runoff from tributaries also was 820 percent of aver 7 ge during water year 1969, total inflow to the Mojave River from ungaged tributaries was about 70,000 acre-ft (about 20,000 acre-ft along the upper main stem, 20,000 acre$\mathrm{ft}$ along the middle main stem, and 30, $\mathrm{C} \cap 0$ acre- $\mathrm{ft}$ along the lower main stem). In comparison, gaged inflow to the Mojave River from the headwaters section during water year 1969 was abcut 340,000 acre-ft.

\section{Manmade Discharges to River}

The discharge from two fish hatcheries has contributed to the flow of the Mojave River along the upper main stem. Discharge from Jess Ranch Fish Hatchery, at about river mile 9 (fig. 4 ), was continuous during water year 1992 and intermittent during water years 1993-94. Historically, wate from the hatchery has been used for irrigation. Beginning in water year 1990, however, ground-water pumpage for the hatchery exceeded irrigation requirements, and the excess was discharged to the river (Gary Ledford, Jess Ranch, oral commun., 1993). With completion of a golf course, irrigation requirements rose in 1994 and discharge to the river occurred only during the winter. The discharge to the river is not metered, but on the basis of periodic discharge measuremerts and the reported operations, it is estimated that about 2,000 acre$\mathrm{ft}$ was discharged to the river in water years 1990 and 1993, about 7,000 acre-ft during water y'ears 1991 and 1992, and about 1,000 acre-ft during water year 1994.

A fish hatchery operated by California Department of Fish and Game (fig. 19) has been discharging water to the river at about mile 10 almost continuously since water year 1949 . Ground water pumped on site is circulated through the fish-rearing ponds and all but about 3,000 acre-ft/yr is discharged to the river. About 3,000 acre-ft/yr historically has been diverted and used for irrigation on the flood plain between the hatchery and Upper Narrows (Richard Uplinger, California Department of Fisl $\backslash$ and Game, 
written commun., 1993). Although the discharge to the river is not metered, an accurate estimate of the discharge is made possible by electric power consumption and efficiency tests on water-supply wells. The estimated discharge to the river varied from about 300 acre-ft during water year 1949 to about 18,000 acre-ft during water year 1991. The estimated total discharge to the Mojave River from both this operation and the Jess Ranch hatchery is shown in figure 20.

At about river mile 22 along the middle main stem of the Mojave River (fig. 4), wastewater from the Victor Valley Wastewater Reclamation Authority has been discharged to the river since water year 1982 . The discharge was metered, and it ranged from about 2,250 acre-ft during water year 1982 to 7,140 acre-ft during water year 1991 (N.B. Allen, Victor Valley
Wastewater Reclamation Authority, written commun., 1994).

Periodically since February 1972, imported water has been released from Silverwood Lake tc the West Fork Mojave River. Through water year 1924, these releases have totaled about 70,000 acre-ft.

Except for a short period in March 1983 when water flowed past Afton Canyon into Soda Lake, all of this water percolated into the Mojave River streambed, mainly along the upper main stem. In addition, beginning in water year 1994, imported water has also been released from a turnout in Mojave Water Agency's Morongo Basin Pipeline at about river mile 4. A total of about 6,600 acre- $\mathrm{ft}$ was released from the turnout in water year 1994, all of which percolated into the streambed within $2 \mathrm{mi}$ (see fig. 15).

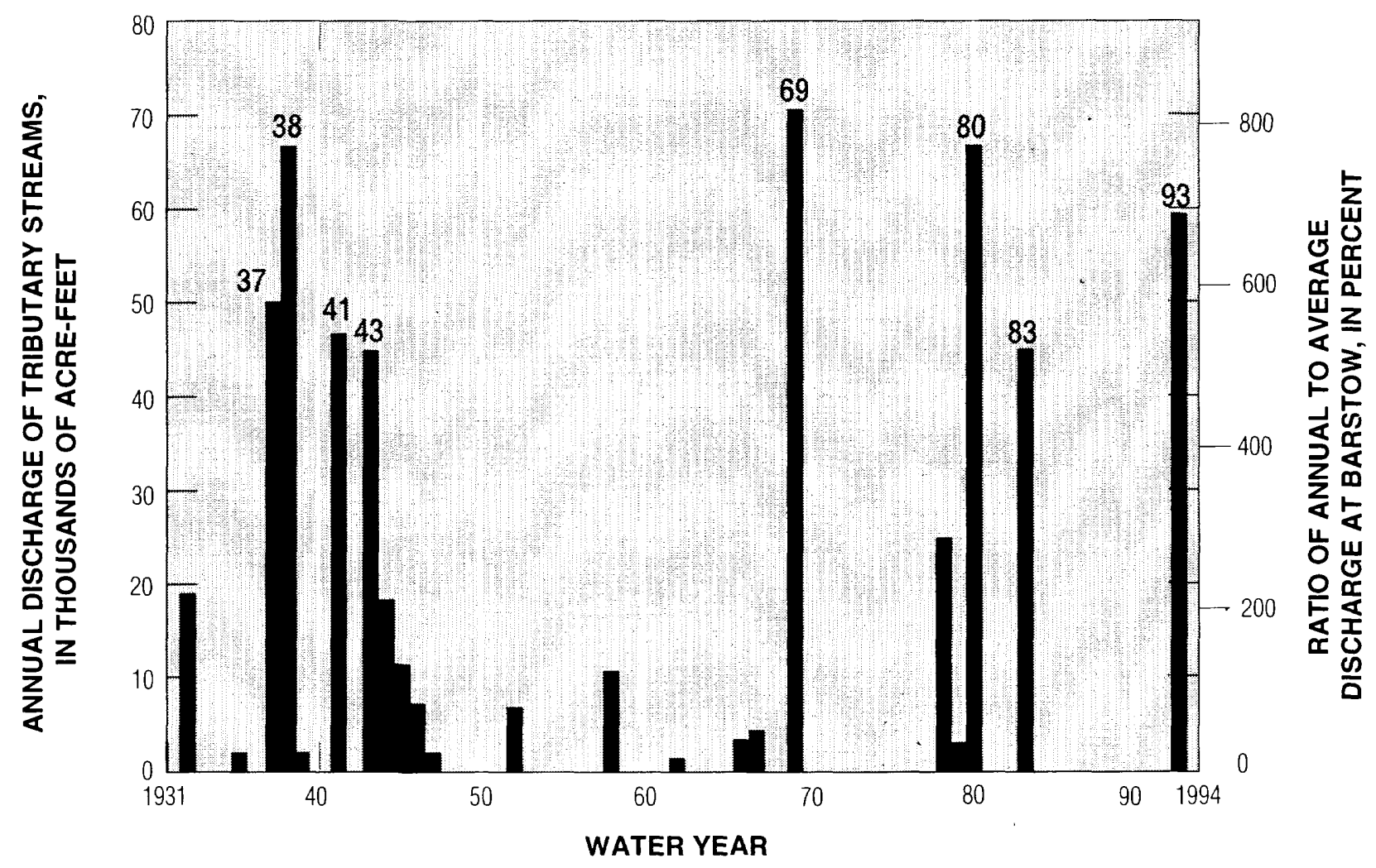

Figure 18. Estimated annual discharge of tributary streams along the main stem of the Mojave River and ratio of annual to average discharge of the Mojave River at Barstow (gaging station 10262500), water years 1931-94. (Selected years are identified at top of bar.) 


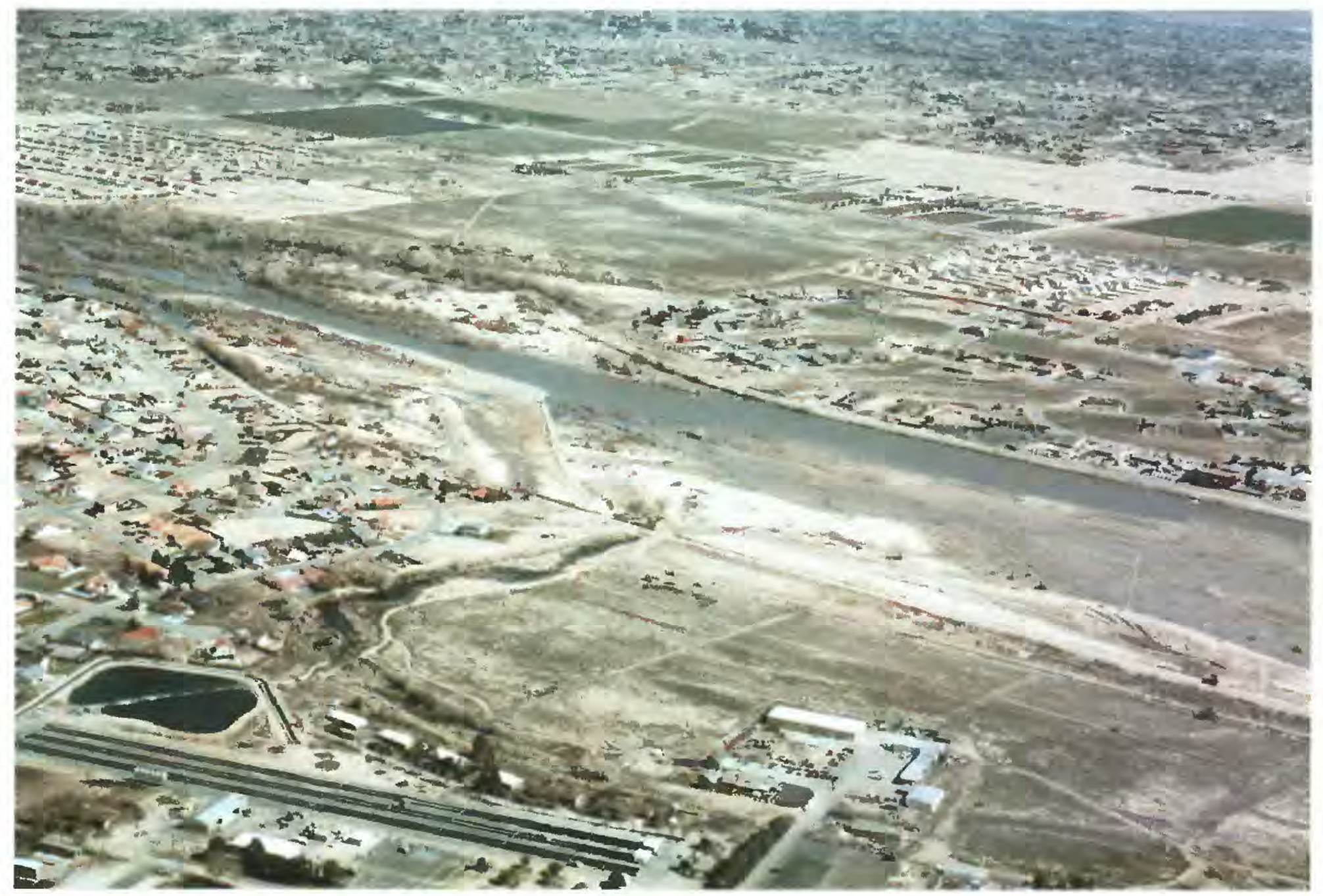

Figure 19. Aerial view of California Department of Fish and Game fish hatchery (left foreground) and discharge to Mojave River, February 25, 1993. (Photograph by Thomas W. Bilhorn.)

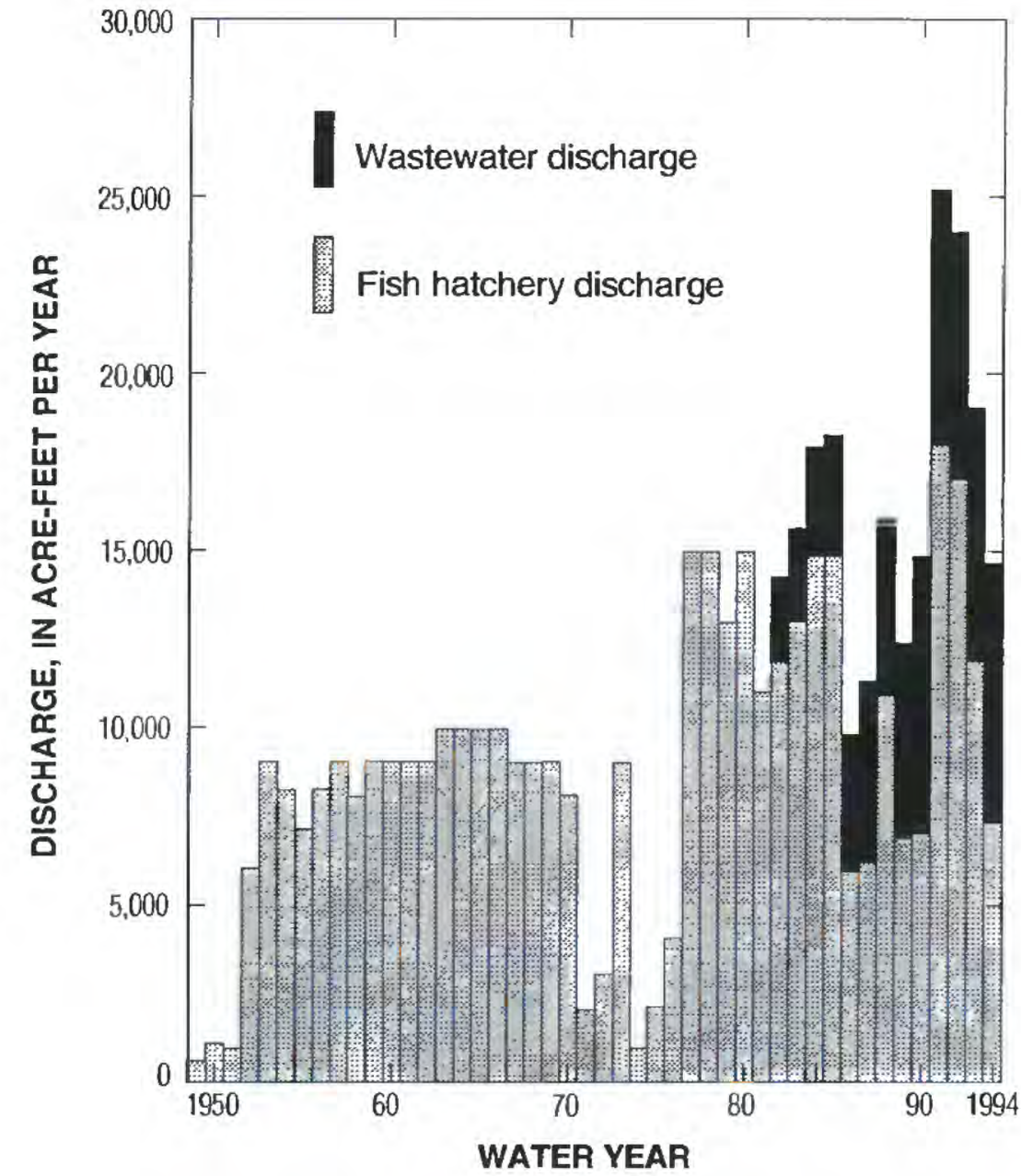

Figure 20. Wastewater and fish hatchery discharges to the Mojave River, water years 1949-94.

\section{THE FLOOD-PLAIN AQUIFER}

\section{Lithology, Thickness, and Extent}

The flood-plain aquifer consists mainly of unconsolidated gravel, sand, and silt of Holocene and Pleistocene age deposited by the Mojave River. Downstream from about river mile 70, the aquifer contains a large amount of silt and clay (Thompson, 1929, fig. 14). The flood-plain aquifer is 150 to $250 \mathrm{ft}$ thick in most places. In the area of the Upper Narrows, the maximum thickness of the aquifer is about $50 \mathrm{ft}$ (Slichter, 1905). The aquifer underlies the Mojave River flood plain and is in direct contact with the river. The flood plain varies in width from about $120 \mathrm{ft}$ at the Upper Narrows to as much as $1.5 \mathrm{mi}$ between Hodge and Lenwood. The flood-plain aquifer, in most places, is underlain by older alluvium, and along the margins of the flood plain the aquifer intertongues with alluvial fans. The older alluvium and the alluvial fans generally are fine grained and commonly are moderately consolidated. In some areas near Barstow and in the Upper and Lower 
Narrows, the flood-plain aquifer is directly underlain by consolidated rocks.

\section{Hydraulic Characteristics}

The flood-plain aquifer is the most productive aquifer in the area, and individual wells typically yield from 100 to $2,000 \mathrm{gal} / \mathrm{min}$. Several wells about $6 \mathrm{mi}$ west of Barstow have been tested at $4,000 \mathrm{gal} / \mathrm{min}$ (Hardt, 1971, p. 11).

Transmissivity of the flood-plain aquifer ranges from 10,000 to $25,000 \mathrm{ft}^{2} / \mathrm{d}$ in most areas (Hardt, 1971, fig. 8). Because of large temporal changes in saturated thickness in some areas, transmissivity of the aquifer can change markedly with time. For example, in the area between Hodge and Barstow, water levels in wells rose as much as $87 \mathrm{ft}$ during the storm runoff of water year 1993 and the transmissivity nearly doubled.

Hardt (1971, fig. 8) simulated flow through the aquifer using an electric analog model, and he varied specific yield from 25 percent along the upper main stem of the river to 20 percent along the middle and lower main stem. For this study, water-level and gravity changes were measured at selected wells, and specific-yield estimates based on these measurements varied from 14 to 39 percent (fig. 21). Specific yields

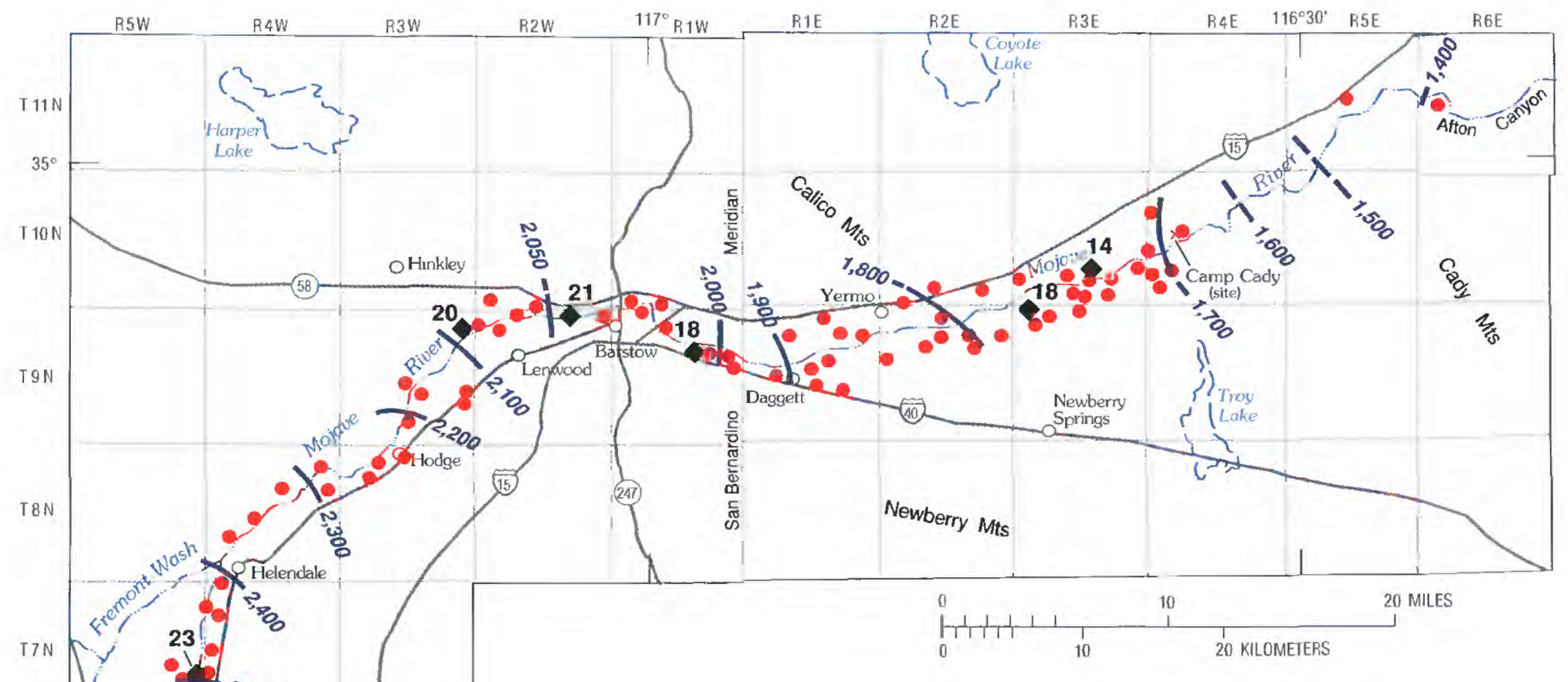

EXPLANATION

2,800 - - Water-table contour-Shows altitude of water table, November 1991. Contour interval 50 and 100 feet. Datum is sea level

Gravity station at observation well--Estimated specific yield of flood-plain aquifer shown in percent

Observation well-- $\mathrm{R}$, continuous water-level recorder

Figure 21. Altitude of the water table in the flood-plain aquifer, November 1991, and estimated specific yield. 
of the aquifer are largest along the upper main stem of the river, and they generally decrease in a downstream direction. For a complete description of theory and methods for using gravity and water-level changes to estimate specific yield, a relatively new technique, the reader is referred to Pool and Eychaner (1995).

\section{The Water Table}

For this study, water levels were measured in about 100 wells in November and March of water years 1992-94. The measurements were used to define the depth to water, the configuration of the water table, and the change in aquifer saturated volume caused by wintertime recharge of river water.

The altitude of the water table in the flood-plain aquifer during November 1991 (shown in fig. 21) decreased in a downstream direction. The difference in altitude for the 100-mile reach between The Forks and Afton Canyon was 1,500 ft. Ground-water flow, which is perpendicular to the water-table contours, was predominantly parallel to the river.

A profile of the Mojave River streambed and the water table during November 1991 and March 1993 is shown in figure 22 . The water-table altitude in November 1991 represented conditions following

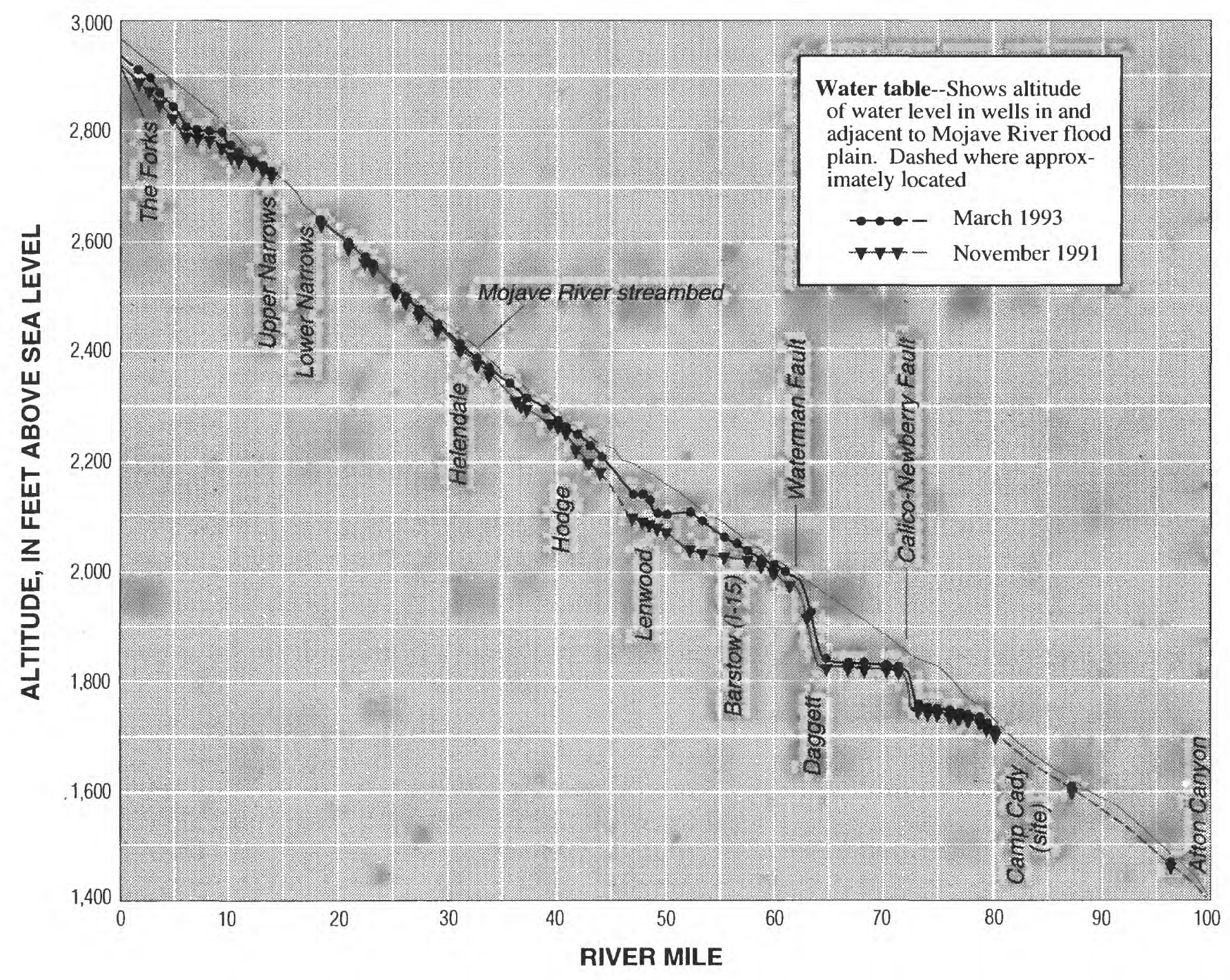

Figure 22. Altitude of Mojave River streambed and altitude of the water table, November 1991 and March 1993. 
several years of below-normal runoff from the headwaters area, and the water table during March 1993 represented conditions following the largest runoff from the headwaters area since 1931. As indicated by the profile, the water table was 20 to $80 \mathrm{ft}$ below the streambed along the first $10 \mathrm{mi}$ of the river below The Forks. Beginning at about river mile 13, the water table was at stream level, and it remained at stream level until about river mile 27. Between river miles 27 and 41 , the water table was less than $25 \mathrm{ft}$ below the stream. At about river mile 52, however, the water table was about $100 \mathrm{ft}$ below the stream in November 1991. Following runoff from major storms during the winter of water year 1993, the water table between Hodge and Barstow rose as much as $87 \mathrm{ft}$, and the water table at mile 52 was only about $20 \mathrm{ft}$ below the river during March 1993.

The effects of the Waterman and CalicoNewberry Faults on the water-table gradient along the lower main stem are shown in figure 22. Both faults impede ground-water flow. Water-table gradients are very steep at the faults, and water-table altitudes upstream and downstream from the faults differ markedly. Downstream from both faults, the watertable gradient is almost flat. Following the stormflows of March 1993, and after most of the lower main stem had ceased to flow, the river continued to flow at the Waterman Fault for a period of several days as water drained from the flood-plain aquifer upstream from the fault.

Because of ground-water pumping, the water table has declined several tens of feet since the early 1900 's in some areas. In reaches of perennial flow in the river, the water-table decline has been much less. On the basis of water-level measurements in wells during 1929-31, the California Department of Public Works (1934, p. 47) reported:

At no place along the stream is the water table distant below the streambed, the greatest depths being about 40 feet five miles below the Forks and abcut 25 feet nine miles above Barstow during the period of this investigation.

A comparison of this statement with the March 1993 water table shown in figure 15 indicates that the greatest water-table declines have occurred downstream from the Waterman and Calico-Newberry Faults and in the Lenwood area.
Two continuous water-level recorders were maintained on wells for this study, and the hydrographs are shown in figure 23. The two wells had markedly different water-level changes. Recorder well No. 1 located along the upper main stem of the river (fig. 21) had seasonal water-level changes of several tens of feet; whereas, water-level changes in recorder well No. 2 along the middle main stem (fig. 21) were only a few feet. Recorder well No. 1 , located at about river mile 3 , is along a reach of the river that was dry during much of water years 1992-94 (fig. 15), but this reach received considerable infiltration of river water during winter months. Recorder well No. 2 , located at about river mile 26 , is near the end of perennial flow along the middle main stem (fig. 15), and the floodplain aquifer was nearly full of water in this area. Consequently, infiltration of winter stormflows in the river during 1993 raised the water table only a few feet.

\section{Historical Pumpage}

Ground-water pumping at most municipal, military, and industrial wells in the Mojave River basin is metered, but most irrigation wells are not metered. Thus, most estimates of pumpage are, in part, based on indirect methods such as electric power consumption and water requirements of irrigated crops.

The first wells utilized by Indians, explorers, and pioneers along the Mojave River were nothing more than shallow depressions dug into the streambed to reach the shallow water table. By the 1880 's, settlement of the region was well underway and more permanent dug wells were utilized. Thompson (1929) reported that by 1917 , about 30 wells along the upper main stem of the Mojave River were being used to irrigate about 5,000 acres of alfalfa. On the basis of irrigated-acreage studies by the California Department of Public Works (1934), Hardt (1971) estimated that ground-water pumpage along the river was about 40,000 acre-ft in 1930.

The first comprehensive surveys of pumpage were completed by Dibble (1967). On the basis of Dibble's work, it is estimated that pumpage from the flood-plain aquifer was about 100,000 acre-ft in 1951 and about 120,000 acre- $\mathrm{ft}$ in 1960 . On the basis of a 


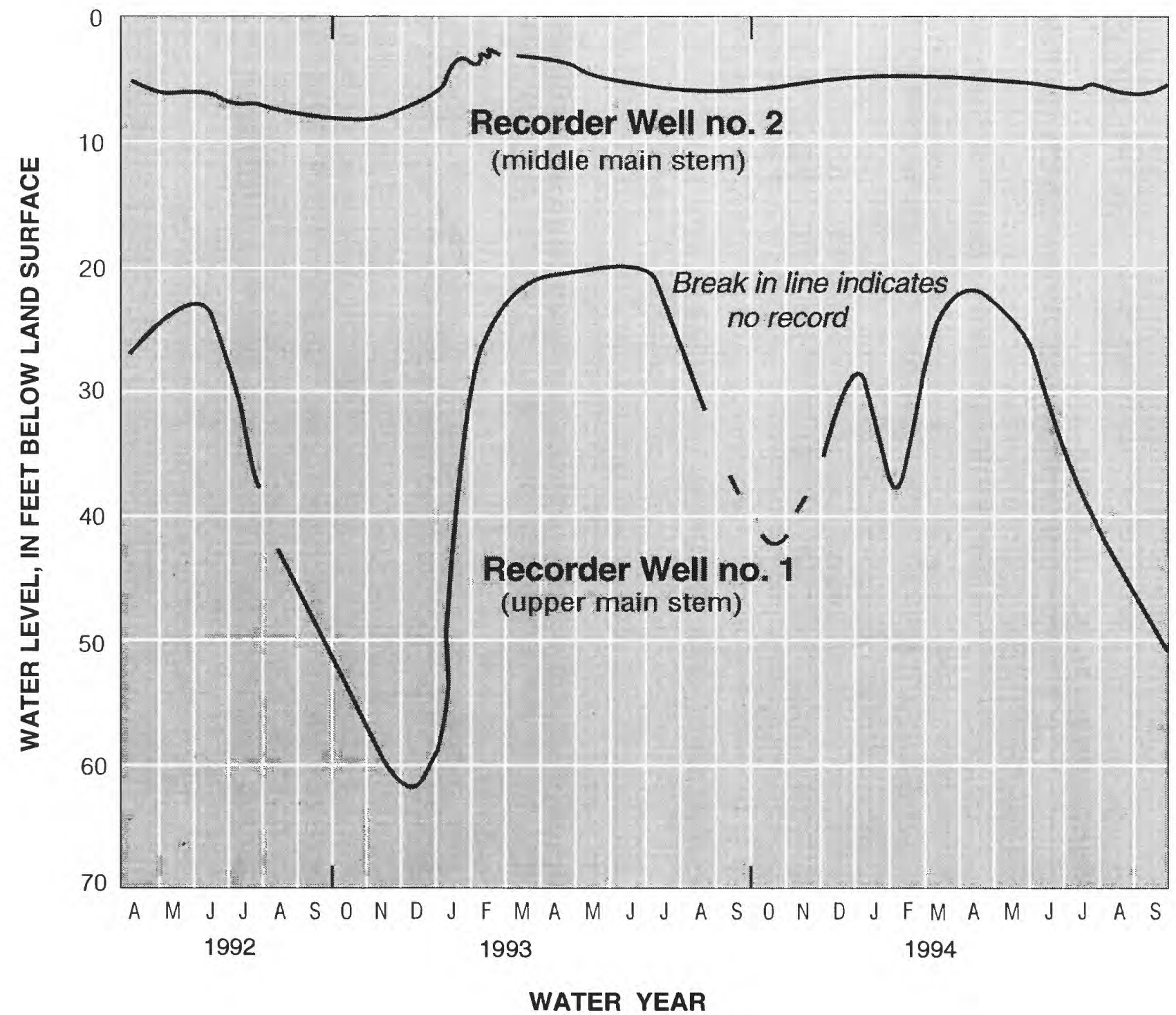

Figure 23. Water levels in flood-plain aquifer at wells along the upper and middle main stem of the Mojave River, April 1992-September 1994.

recent inventory of pumpage completed for the Mojave River basin adjudication (James C. Hanson, written commun., 1995), pumpage from the floodplain aquifer during 1994 also is estimated to have been about 120,000 acre-ft. Of this 1994 total, about 50,000 acre-ft was pumped from the flood-plain aquifer along the upper main stem of the Mojave River, about 50,000 acre-ft along the middle main stem, and about 20,000 acre-ft along the lower main stem.

\section{GROUND-WATER DISCHARGE TO RIVER}

One objective of this study was to determine the quantity of ground-water discharge to the Mojave River. During water years 1992-94, groundwater discharged primarily along two reaches of the main stem-between approximately river miles 12 and 18 in the Upper and Lower Narrows area and between river miles 99 and 100 near the mouth of Afton Canyon. As mentioned earlier, ground water also discharged at the 
Waterman Fault (about river mile 60) for a few days in March 1993 following wintertime storm runoff and filling of the flood-plain aquifer immediately upstream from the fault. Total discharge to the river at the fault was probably less than 100 acre-ft.

Hydrographs of mean daily discharges at gaging stations near Victorville and Afton Canyon, similar to those of figures 11 and 13, were used to estimate ground-water discharge upstream from the gages. Several researchers (Barnes, 1939 and 1940; Chow, 1964; Daniel and others, 1970; and Linsley and others, 1975) have proposed different empirical procedures to analyze and separate various flow components of streamflow hydrographs. During many years, the river flow near Victorville and in Afton Canyon consists entirely of ground-water discharge, and thus the base flow is easily determined (for example, see water years 1950 and 1989 in fig. 11). However, during most years, some storm runoff occurs, and the task becomes one of separating the base flow from the total flow.

For aquifers such as the flood-plain aquifer along the Mojave River, that both discharge water to the stream during non-storm periods and that are recharged almost entirely by the stream during storm runoff, the hydrograph-separation procedure proposed by Daniel and others (1970) is the most appropriate procedure. This procedure, unlike others, allows for the cessation of discharge from the aquifer to the stream during times when flow is actually in the opposite direction and the aquifer is being recharged by the stream. Because the procedure, to the author's knowledge, has not been fully utilized in any other study, it will be described here in some detail.

An idealized (dimensionless) hydrograph of a stream immediately preceding, during, and following a single peak in discharge caused by overland storm runoff is shown in figure 24 . The hydrograph consists basically of three segments: The approach segment $(a b)$, a rising segment $(b c)$, and the recession segment $(\mathrm{cg})$. On these segments, $b$ represents the point of rise in stream discharge, $c$ represents the peak in discharge, $d$ represents a point of inflection, and $e, f$, and $g$ are three other characteristic points on the recession segment.

During the approach segment $(a b)$, the aquifer is draining to the stream and all streamflow is base flow.
At point $b$, overland storm runoff reaches the stream, and the discharge increases until it peaks at point $c$. At point $b$, stage in the river begins to rise and the hydraulic gradient between the stream and aquifer decreases, resulting in a decrease of discharge from the aquifer to the river. Shortly after point $b$, at which a reversal occurs in hydraulic gradient between stream and aquifer, the aquifer ceases to discharge to the stream (base flow is zero) and, instead, begins to be recharged by the stream.

The ground-water discharge (base flow) remains at zero until the stream peaks and point $d$ (point of inflection) on the recession segment is reached. At point $d$, the falling stage in the river no longer exceeds the hydraulic head in the aquifer, and the hydraulic gradient once again reverses. At point $d$, groundwater again begins to discharge to the stream, and recharge from the stream ceases. Between points $d$ and $e$, the river stage continues to decline, the hydraulic gradient between the aquifer and stream increases, and likewise the ground-water discharge to the stream also increases. At point $f$, all streamflow is once again base flow. The base flow recedes between points $f$ and $g$ at a rate that is the same as the initial rate between points $a$ and $b$.

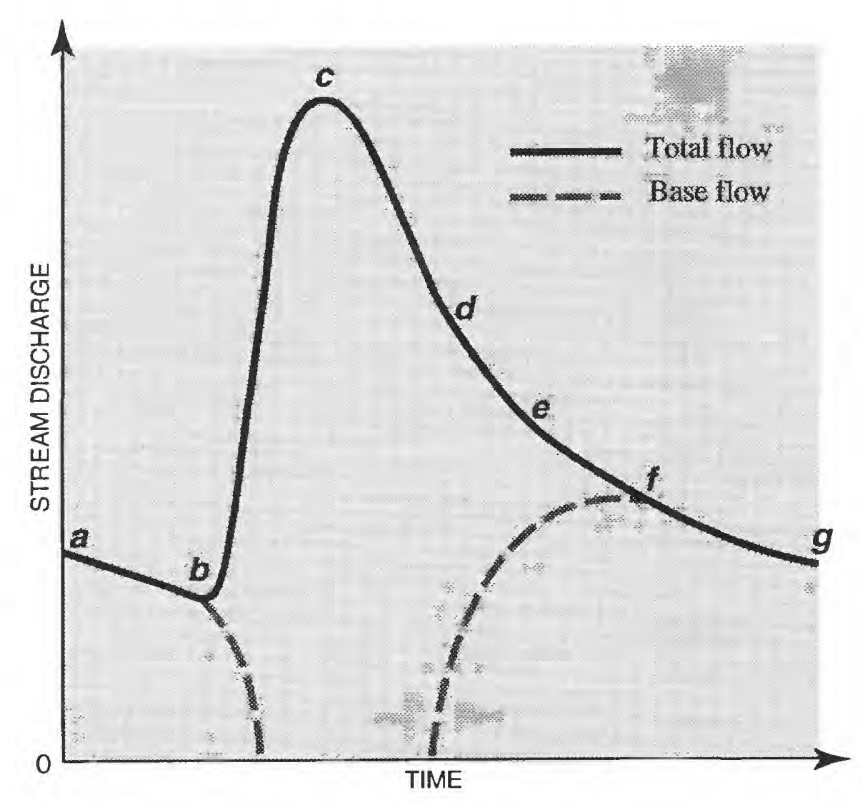

Figure 24. Idealized streamflow-hydrograph separation. (Letters $a-g$ are time points referred to in text.) 
Several factors, most notably ground-water pumping and evapotranspiration, can markedly alter the shape of streamflow hydrographs during periods of base flow. Thus, many times the selection of points $d$, $e, f$, and $g$ is not only arbitrary but also difficult. For practical purposes, accurate estimates of base flow can be made by assuming that at point $b$ (point of rise in stream stage) the base flow immediately drops to zero, and likewise, the base flow remains at zero until point $e$ (midway between $d$ and $f$ ) where it instantaneously rises and equals the stream discharge. As Daniel and others (1970) point out, there is little loss in accuracy by separating the base flow and stormflow in such a manner, especially if one is using hydrographs of daily mean discharge. Also, water entering or leaving "bank storage" (Daniel and others, 1970) is considered ground-water recharge or discharge, and it is not accounted for separately.

The technique is illustrated (fig. 25) for the gaging station at the Lower Narrows during water year 1982. As shown in figure 25 , there were three peaks in storm runoff that required hydrograph separation to estimate base flow. The first was a single, simple peak similar to the idealized peak in figure 24 , and the second and third peaks followed in quick succession without the river reaching ground-water discharge conditions (point $d$ ) between peaks.

Ground-water discharge (base flow) from the flood-plain aquifer represents a significant part of Mojave River flow near Victorville, averaging about

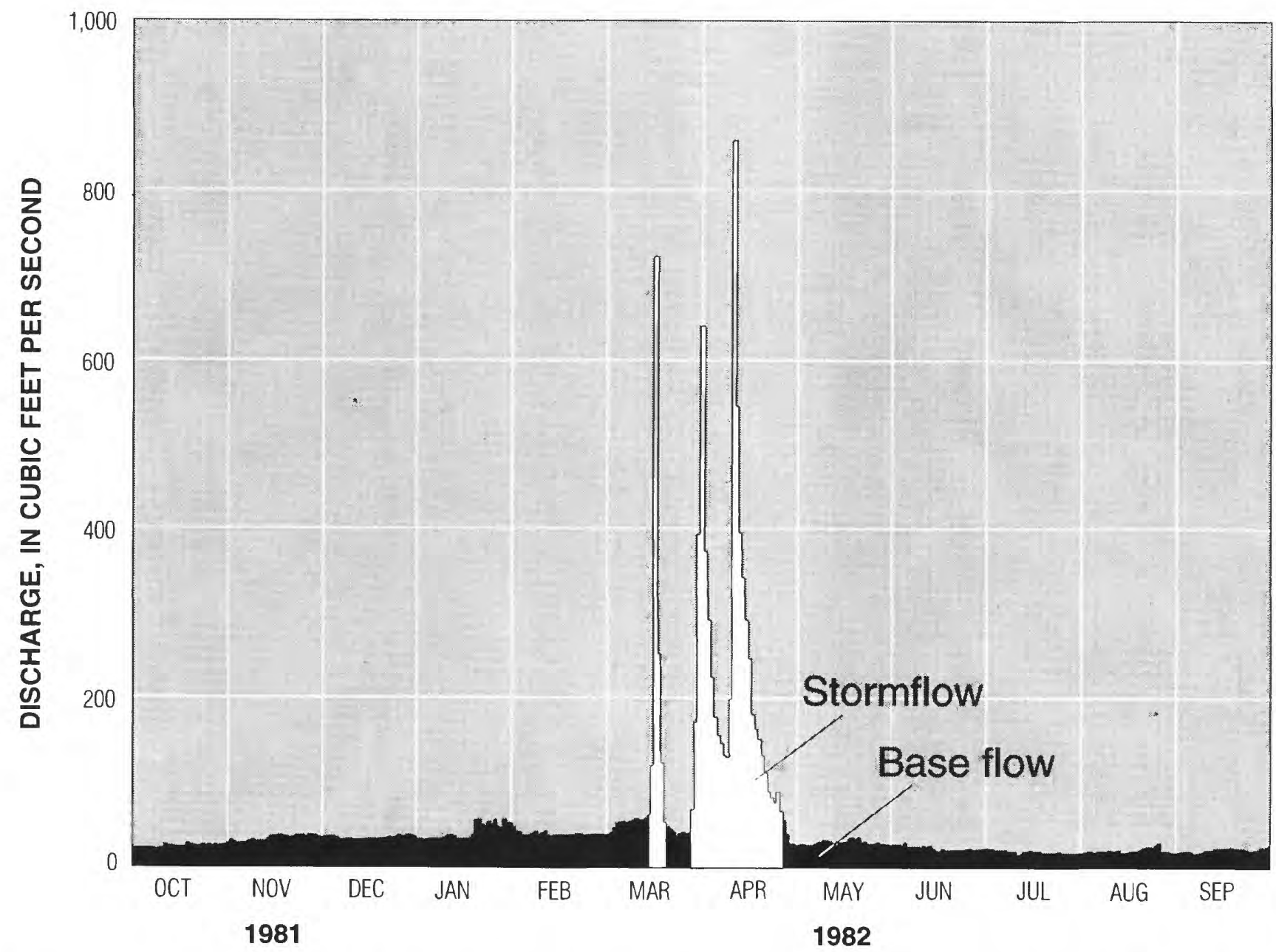

Figure 25. Estimated stormflow and base flow for the Mojave River at Lower Narrows (gaging station 10261500) during water year 1982. 
37 percent of the total flow since water year 1931. During some years, for example 1950 and 1989, all flow at Victorville was due to ground-water discharge because there was no storm runoff. The estimated annual base flow of the Mojave River near Victorville (gaging station 10261500) is shown in figure 26. Since water year 1900 , there has been a long-term decline in base flow. During water years 1900-01 and 1904-05 when the gaging station was at the Upper Narrows, annual base flow averaged about 30,000 acre-ft. Later, during water years 1931-36 with the gage still at the Upper Narrows, the annual base flow averaged about 22,000 acre- $\mathrm{ft}$. During the first six years at the Lower Narrows, water years 1937-42, annual base flows averaged about 26,000 acre-ft. The difference between water years 1931-36 and 1937-42 mainly reflects an increase due to ground-water discharge between the Upper and Lower Narrows. During the 1950's and early 1960 's, the base flow steadily declined and was only about 14,000 acre-ft during water year 1967. The decline in base flow was temporarily reversed in the late 1960's and late 1970's as a result of large inflows from the headwaters and recharge to the flood-plain aquifer during water years 1969, 1978, 1980, and 1983. The base flow reached an all-time low of about 4,000 acre-ft during water

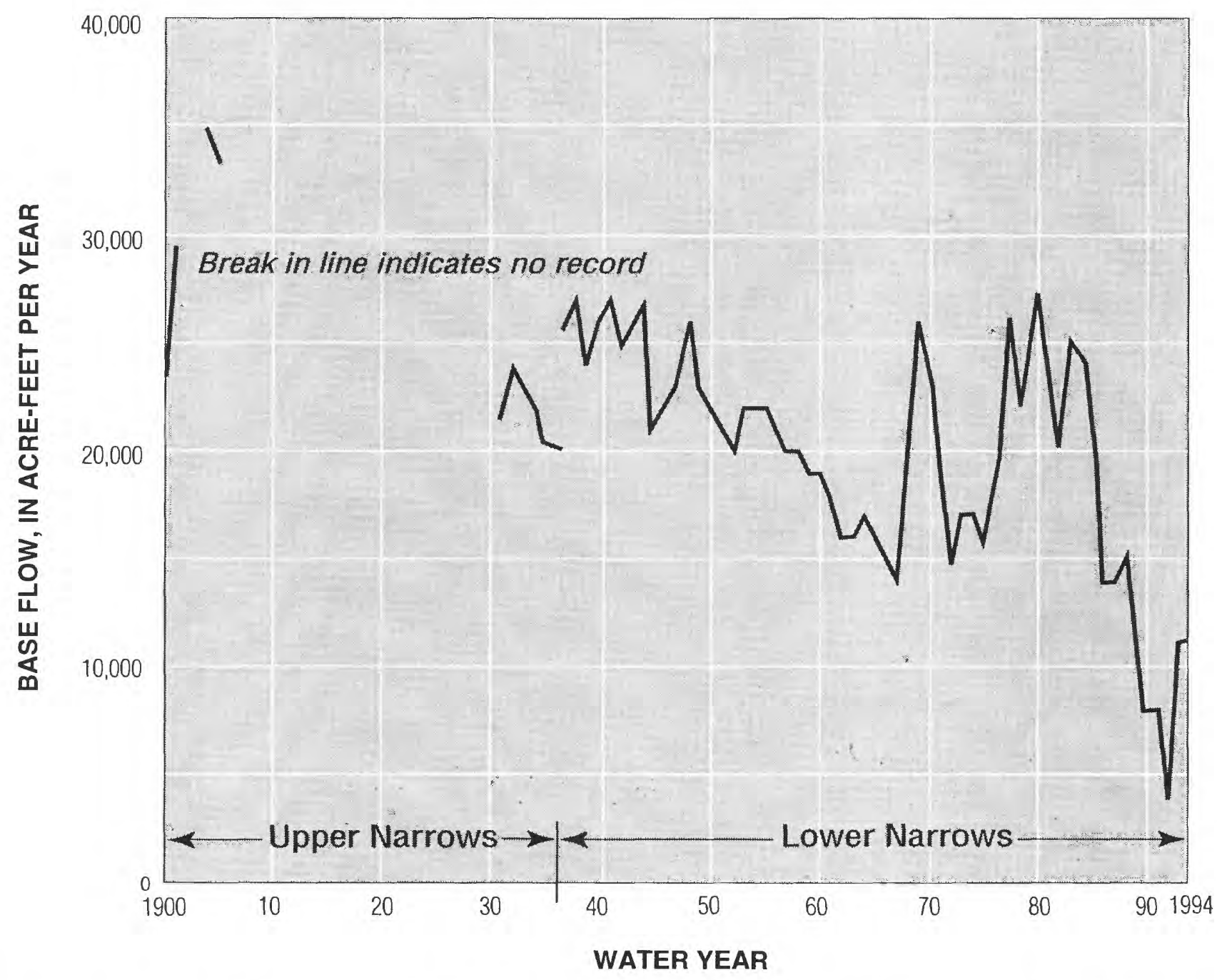

Figure 26. Base flow of Mojave River near Victorville (gaging station 10261500) during water years 1900-01, 1904-05, and 1931-94. 
year 1992. After the large inflow from the headwaters during water year 1993, base flow increased to about 11,000 acre-ft during water years 1993 and 1994.

Estimated annual base flow of the Mojave River at Afton Canyon (gaging station 10263000) is shown in figure 27. Whereas ground-water discharge near
Victorville accounted for about 37 percent of the river flow, ground-water discharge from the flood-plain aquifer above the gage in Afton Canyon has accounted for about 7 percent of the total river flow since water year 1930. Stormflow has accounted for the remainder. During water years 1930-32, the first 3 years

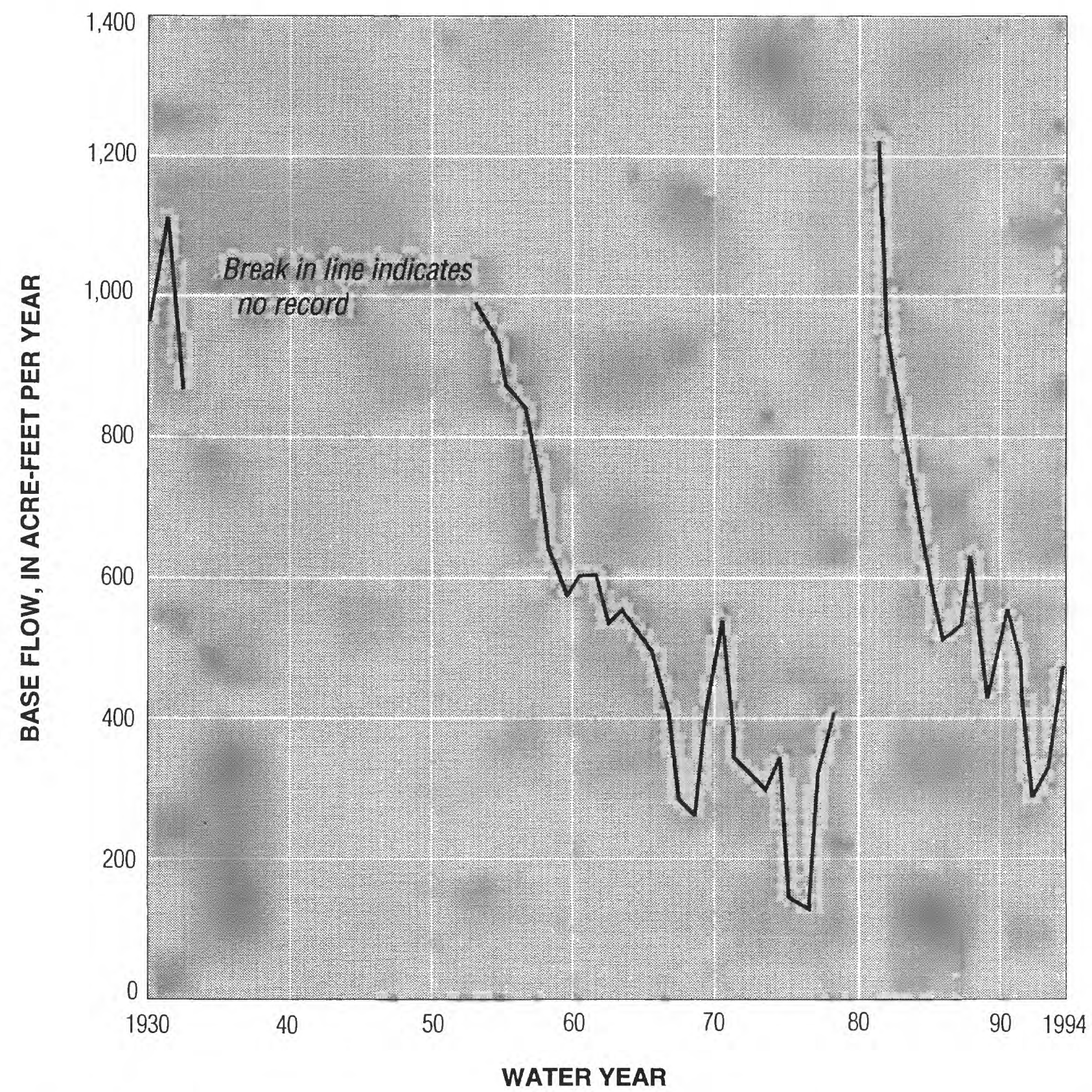

Figure 27. Base flow of Mojave River at Afton Canyon (gaging station 10263000) during water years 1930-32, 1953-78, and 1981-94. 
of gage operation at Afton Canyon, annual base flow averaged about 980 acre-ft. Following reinstallation of the gage during water year 1953, base flow generally declined until reaching a low of about 130 acre-ft during water year 1976. Large quantities of runoff and ground-water recharge during water year 1969 are reflected in the reversal of this decline, with base flow increasing to about 400 and 530 acre-ft during water years 1969 and 1970. The gage was not in operation for the large-runoff year of 1980, but during water year 1981 the annual base flow was at an all-time high for the period of record of about 1,200 acre-ft. Again the base flow generally declined, and it was only about 280 acre-ft during water year 1992 . Following the large quantity of runoff in water year 1993, base flow at Afton Canyon was about 470 acreft during water year 1994 .

While ground water continued to discharge to the river at the Lower Narrows and in Afton Canyon during water year 1994, the flood-plain aquifer was no longer discharging to other reaches of the river that previously had some base flow. As pointed out earlier, Camp Cady (river mile 82), Fork of Roads (mile 70), Fish Pond (mile 60), Grapevine (mile 55), Cottonwoods (mile 41), Point of Rocks (mile 34), and Lane's Crossing (mile 20) all were camping sites used by the explorers and pioneers of the 1800 's because water was available from the river or shallow dug wells year round. When the base flow ceased at these sites is not known precisely, but the base flow at Camp Cady reportedly ceased in the early 1980's. Base flow at Forks of Road (at the Calico-Newberry Fault) probably ceased in the early 1960's, on the basis of marked changes in riparian vegetation that can be seen in aerial photographs. The river flowed at Fish Pond (Waterman Fault) for only a few days in late March 1993 following the large quantity of runoff and aquifer recharge of the previous 3 months. Children were reportedly still using a pond near the Grapevine (in Barstow) for swimming as late as the 1950's. When base flow may have ceased at Cottonwoods (the probable camp site of Father Francisco Garcés on March $16,1776)$ and at Point of Rocks is unknown. Perennial flow at Lane's Crossing last occurred during water year 1992, mainly due to leakage of wastewater from an underground pipe, and the river was dry at this site much of water year 1994 (see fig. 15). Total annual ground-water discharge to the river at these sites is unknown, but it probably was a few hundred acre-feet at each site. Although some of the water was lost to evapotranspiration, much of the water probably reinfiltrated into the streambed within a short distance downstream.

\section{GROUND-WATER RECHARGE FROM RIVER}

Recharge to the flood-plain aquifer from infiltration of Mojave River water can be computed from measured streamflow losses between gaging stations and estimates of tributary inflow, base flow, manmade discharges, and evaporation of river water between the gages. The estimates of annual recharge to the flood-plain aquifer along the upper, middle, and lower main stem during water years 1931-94 are given in table 3 and plotted cumulatively in figure 28 . Previous estimates of recharge during water years 1969 and 1978 (Buono and Lang, 1980) are revised on the basis of estimated tributary inflow, base flow, and manmade discharges to the river.

The method and the computations for estimating recharge during water year 1993 are described herein. For the upper main stem, inflow from the headwaters (combined annual flow of gaging stations 10261000 and 10260950) in water year 1993 was about 430,000 acre- $\mathrm{ft}$. The annual discharge at the gaging station at the Lower Narrows (10261500) was 290,000 acre-ft. Therefore, the net streamflow loss along the upper main stem of the Mojave River was about 140,000 acre-ft. Inflow along the upper main stem during water year 1993 included about 20,000 acre-ft from ungaged tributary streams, about 11,000 acre- $\mathrm{ft}$ of ground-water discharge to the river (base flow) at The Narrows, and about 12,000 acre-ft from fish hatcheries. There were no diversions from the upper main stem, and direct evaporation from the river was about 100 acre-ft on the basis of an estimated average river area of 22 acres and an annual free-water-surface evaporation of $65 \mathrm{in}$. (National Oceanic and Atmospheric Administration, 1982). By adding all inflow to the net streamflow loss and subtracting the river evaporation, one obtains an estimate for groundwater recharge from the upper main stem of the river of 180,000 acre- $\mathrm{ft}$ (rounded) during water year 1993 $(140,000$ acre-ft $+20,000$ acre- $f t+11,000$ acre-ft + 12,000 acre-ft -100 acre- $f t=182,900$ acre-ft). 
Similarly - for the middle main stem, the net streamflow loss between the gaging station at the Lower Narrows (10261500) and the gaging station at Barstow (10262500) was 160,000 acre-ft during water year 1993. Inflow between the gages included about 20,000 acre-ft from ungaged tributary streams and 6,900 acre-ft of wastewater discharge. Evaporation from the river surface was about 200 acre-ft on the basis of an estimated average river area of 32 acres and an annual free-water-surface evaporation of $75 \mathrm{in.}$ (National Oceanic and Atmospheric Administration, 1982). Thus, ground-water recharge from the middle main stem was about 190,000 acre-ft (rounded).

Finally-for the lower main stem, net streamflow loss between the gaging station at Barstow (10262500) and the gaging station at Afton Canyon (10263000) was 56,000 acre-ft during water year
1993. Inflow between the gages included about 30,000 acre-ft from ungaged tributary streams and about 330 acre-ft of ground-water discharge to the river (base flow at Afton Canyon). Evaporation from the river surface was about 5 acre- $\mathrm{ft}$, on the basis of an estimated average river area of 0.7 acre and an annual free-water-surface evaporation of 80 in. (National Oceanic and Atmospheric Administration, 1982). Thus, ground-water recharge from the lower main stem was about 86,000 acre-ft (rounded).

The plot of cumulative annual recharge (fig. 28) indicates that the flood-plain aquifer along the upper and middle main stem receives some recharge each year; whereas the aquifer along the lower main stem is recharged only during years of large runoff (for example, water years $1969,1980,1983$, and 1993). Also, recharge along the upper and middle main stem

Table 3. Estimated annual recharge to the flood-plain aquifer from the Mojave River, water years 1931-94 [Recharge in thousands of acre-feet]

\begin{tabular}{|c|c|c|c|c|c|c|c|c|c|c|c|}
\hline \multirow{2}{*}{$\begin{array}{l}\text { Water } \\
\text { year }\end{array}$} & \multicolumn{3}{|c|}{ Main stem reach } & \multirow{2}{*}{$\begin{array}{l}\text { Water } \\
\text { year }\end{array}$} & \multicolumn{3}{|c|}{ Main stem reach } & \multirow{2}{*}{$\begin{array}{c}\text { Water } \\
\text { year }\end{array}$} & \multicolumn{3}{|c|}{ Main stem reach } \\
\hline & Upper & Middle & Lower & & Upper & Middle & Lower & & Upper & Middle & Lower \\
\hline 1931 & 18 & 22 & 0 & 1953 & 18 & 22 & 0 & 1975 & 18 & 16 & 0 \\
\hline 1932 & 51 & 52 & 39 & 1954 & 53 & 31 & 0 & 1976 & 26 & 20 & 0 \\
\hline 1933 & 25 & 24 & - & 1955 & 25 & 22 & 0 & 1977 & 24 & 28 & 0 \\
\hline 1934 & 18 & 24 & -- & 1956 & 23 & 22 & 0 & 1978 & 200 & 170 & 14 \\
\hline 1935 & 48 & 33 & -- & 1957 & 30 & 20 & 0 & 1979 & 79 & 67 & ${ }^{1} 6$ \\
\hline 1936 & 28 & 20 & - & 1958 & 82 & 81 & 22 & 1980 & 140 & 110 & ${ }^{2} 100$ \\
\hline 1937 & 59 & 56 & -- & 1959 & 26 & 20 & 0 & 1981 & 26 & 23 & 0 \\
\hline 1938 & 76 & 70 & -- & 1960 & 18 & 19 & 0 & 1982 & 54 & 37 & 0 \\
\hline 1939 & 35 & 29 & -- & 1961 & 12 & 19 & 0 & 1983 & 120 & 110 & 100 \\
\hline 1940 & 29 & 27 & -- & 1962 & 65 & 26 & 1 & 1984 & 41 & 30 & 0 \\
\hline 1941 & 58 & 60 & -- & 1963 & 15 & 17 & 0 & 1985 & 38 & 25 & 0 \\
\hline 1942 & 25 & 25 & -- & 1964 & 20 & 17 & 0 & 1986 & 49 & 21 & 0 \\
\hline 1943 & 61 & 49 & -- & 1965 & 31 & 17 & 0 & 1987 & 17 & 18 & 0 \\
\hline 1944 & 41 & 46 & -- & 1966 & 91 & 45 & 3 & 1988 & 27 & 21 & 0 \\
\hline 1945 & 40 & 35 & -- & 1967 & 78 & 68 & 8 & 1989 & 18 & 17 & 0 \\
\hline 1946 & 35 & 33 & -- & 1968 & 33 & 19 & 0 & 1990 & 15 & 16 & 0 \\
\hline 1947 & 37 & 35 & -- & 1969 & 100 & 160 & 100 & 1991 & 54 & 18 & 0 \\
\hline 1948 & 13 & 26 & -- & 1970 & 37 & 23 & 0 & 1992 & 72 & 31 & 0 \\
\hline 1949 & 23 & 23 & -- & 1971 & 22 & 20 & 0 & 1993 & 180 & 190 & 86 \\
\hline 1950 & 13 & 21 & -- & 1972 & 19 & 23 & 0 & 1994 & 45 & 18 & 0 \\
\hline 1951 & 3 & 21 & -- & 1973 & 55 & 34 & 0 & & & & \\
\hline 1952 & 64 & 56 & -- & 1974 & 27 & 18 & 0 & & & & \\
\hline
\end{tabular}

\footnotetext{
${ }^{1}$ Estimated from similar streamflow conditions during water year 1967.

${ }^{2}$ Estimated from percentage of flow at Barstow that was recharged along the lower main stem during water years 1969 and 1993.
} 
was comparable until the early 1950 's when several thousand acre-feet of fish-hatchery water began to be discharged each year to the upper main stem-thus recharging the flood-plain aquifer. Annual recharge along the upper main stem averaged about 46,000 acre-ft during water years 1931-94, and recharge along the middle main stem averaged about 39,000 acre-ft during this same period. During the 44 years that the annual recharge can be estimated along the lower main stem (water years 1931-32 and 1953-94), it averaged about 11,000 acre-ft.
Changes in ground-water storage can be estimated if changes in water-table altitude and the specific yield of the aquifer are known. On the basis of the water-table rise from November 1992 to March 1993 (fig. 29), the saturated volume of the flood-plain aquifer increased by about 1,300,000 acre-ft. Using an average specific yield of 34 percent for the upper main stem, 22 percent for the middle main stem, and 17 percent for the lower main stem, the author estimates that ground-water storage increased by about 300,000 acre-ft during November 1992-March 1993.

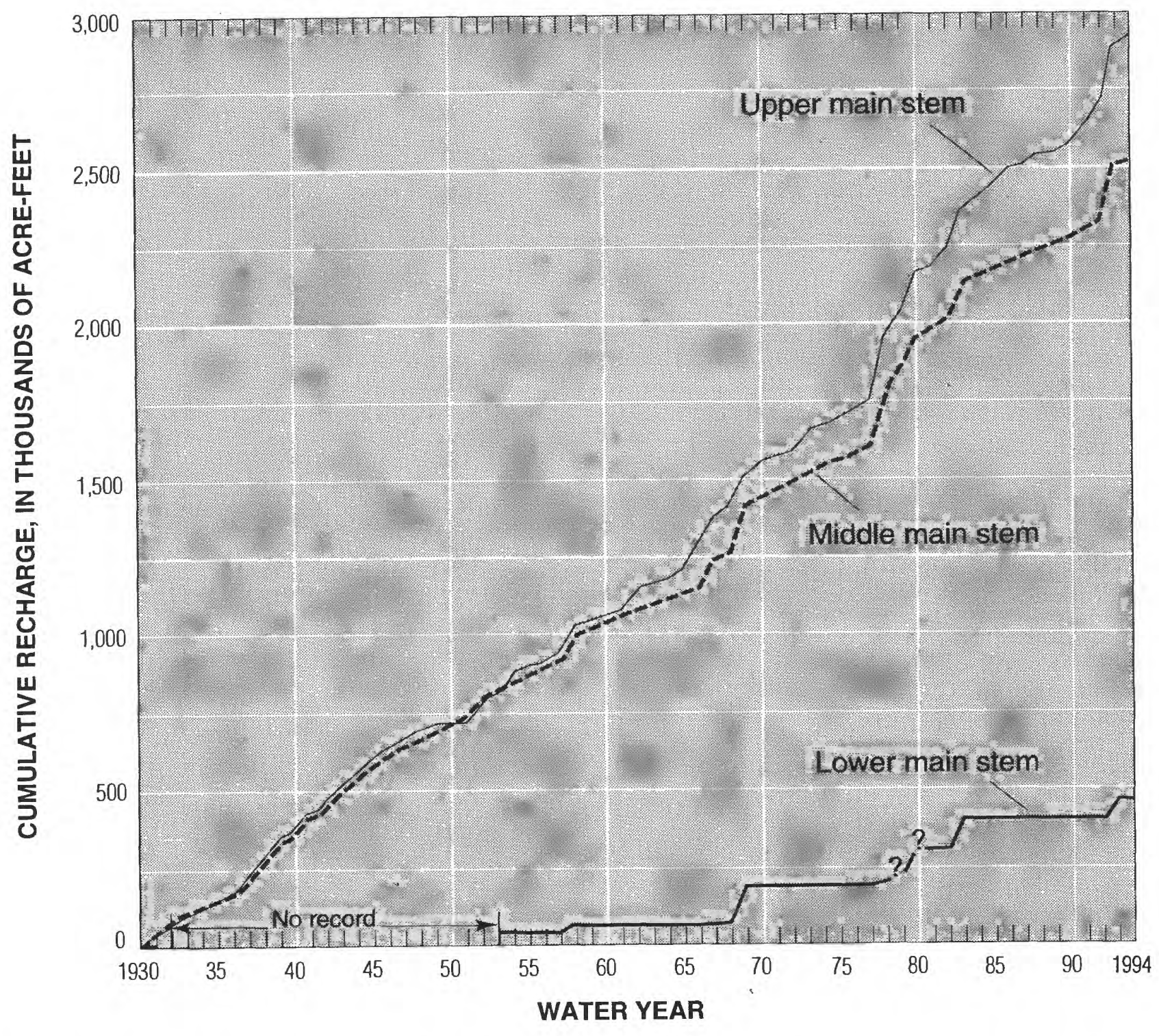

Figure 28. Cumulative annual recharge to the flood-plain aquifer from the Mojave River along the upper and middle main stem during water years 1931-94 and along the lower main stem during water years 1931-32 and 195394.(Queried where uncertain; see table 3.) 
Water-table-change maps also were prepared for the periods November 1991 to March 1992 and November 1993 to March 1994, but the maps are not included in this report. It is estimated, using the method described above, that recharge to the floodplain aquifer exceeded discharge, and ground-water storage increased by about 50,000 acre-ft during November 1991-March 1992 and by about 30,000 acre-ft during November 1993-March 1994. Because the river was dry along the lower main stem all of water years 1992 and 1994, except for base flow at Afton Canyon, all of the recharge to the flood-plain aquifer occurred along the upper and middle main stem.

Water-table change maps similar to figure 29 are useful in determining the areas between the gaging stations that did or did not receive recharge from the river. For example, water-table rises during the winter of 1993 indicate that ground-water recharge along the upper main stem occurred mainly along ephemeral reaches of the river between miles 0 and 10. Along the middle main stem, most of the recharge occurred between Hodge and Barstow; likewise, most of the recharge along the lower main stem occurred upstream
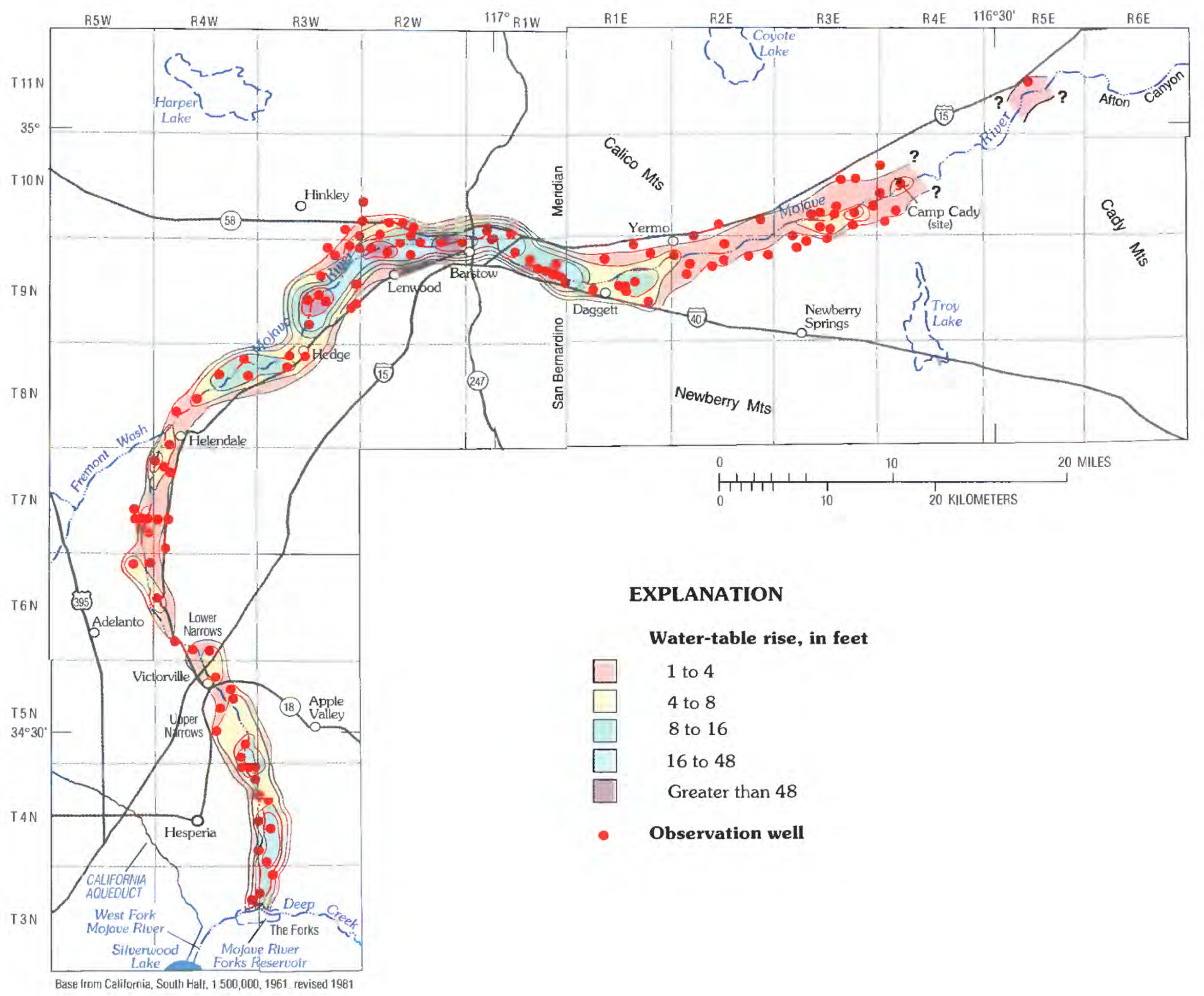

Figure 29. Areas of water-table rise along the Mojave River, November 1992 to March 1993. 
from Daggett. Such observations also are useful in the preliminary siting of artificial-recharge facilities that will rely on infiltration of water through the streambed or surface of the flood plain.

\section{STREAMFLOW DEPLETION}

Withdrawals from the flood-plain aquifer, by both ground-water pumping and transpiration by phreatophytes, cause depletions in streamflow. The withdrawals from the aquifer may cause river water to enter the aquifer, or they may "capture" ground water that normally would have been discharged to the river. In either case, the net effect is the same-a depletion in streamflow.

The magnitude and timing of the streamflow depletion depend on the transmissivity of the aquifer $(T)$, the specific yield $(S y)$, and the distance from the point of stress (well or phreatophyte) to the river $(r)$. Jenkins $(1968 \mathrm{a}, \mathrm{b})$ developed a parameter known as stream-depletion factor (sdf) that characterizes these three variables. The sdf is equal to the distance squared times the specific yield divided by transmissivity $\left(r^{2} S y / T\right)$, and it is expressed in units of days.

The use of sdf in determining streamflow depletion can be illustrated by an example (fig. 30). Consider a well $720 \mathrm{ft}(r)$ from the river that is pumped for 1 month and then turned off. For this example, the transmissivity $(T)$ is assumed to be $13,000 \mathrm{ft}^{2} / \mathrm{d}$ and the specific yield $(\mathrm{Sy}) 25$ percent;

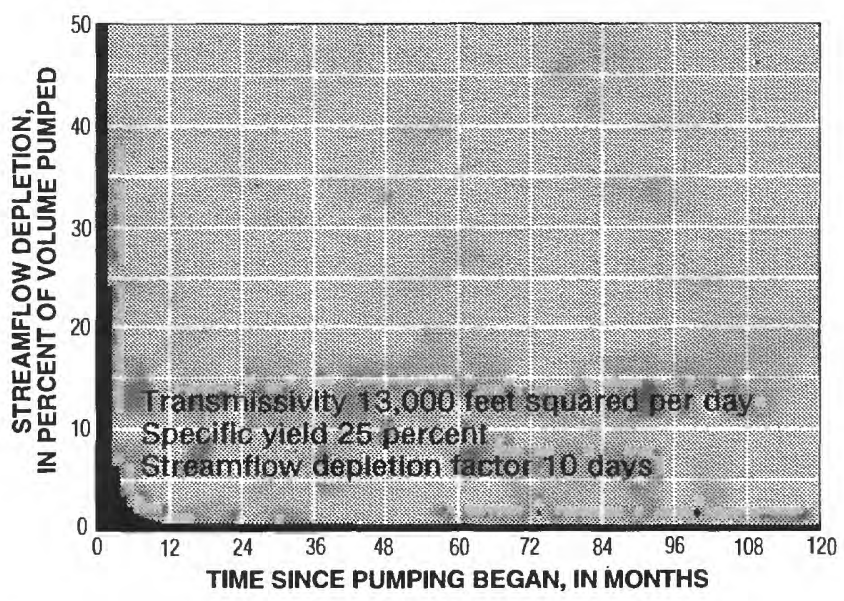

Figure 30. Streamflow depletion by a well that is pumped continuously for one month 720 feet from a stream. (Modified from Burns, 1983.) thus, sdf is 10 days. The graph shows the percentage of the volume pumped that comes from the stream or is prevented from entering the stream-this is the streamflow depletion. During the 1 month that the well is pumped, the river will be depleted by about 50 percent of the total volume pumped. During the second month (after pumping has ceased), the river will be depleted by about 24 percent of the volume pumped the first month. As can be seen from the graph, the effects of pumping are small after a few months, but they have not completely dissipated even after 10 years ( 120 months).

A series of curves for a range of sdf values is shown in figure 31 . The curves show the streamflow depletion that would be caused by continuously pumping a well for 60 months (5 years) at various distances from the river. As in the previous example, it is assumed that transmissivity of the flood-plain aquifer is $13,000 \mathrm{ft}^{2} / \mathrm{d}$ and specific yield is 25 percent. As indicated, a continuously pumped well $720 \mathrm{ft}$ from the river ( $\mathrm{sdf}=10 \mathrm{~d}$ ) will deplete stream- flow by about 50 percent of the first month's pumpage, by about 80 percent of the first year's pumpage, and by about 91 percent of the first 5 years' pumpage.

The curves in figure 31 can be used to estimate streamflow depletion for any combination of $r, S y$, and $T$. For example, for a well $1,500 \mathrm{ft}$ from the river in an area where the specific yield is 30 percent and transmissivity is $20,000 \mathrm{ft}^{2} / \mathrm{d}$, sdf would be equal to 34 days, and the curve for $\mathrm{sdf}=30$ days could be used. It should be noted that simplifying assumptions (discussed by Jenkins, 1968a,b) may preclude the use of the curves for a particular location of interest. Also, Wallace and others (1990) discuss the appropriate analytical techniques to determine streamflow depletion for wells with cyclic pumping, such as agricultural irrigation wells.

In addition to the analytical techniques that can be used for individual wells, streamflow records at gaging stations can be used to estimate regional streamflow depletion by wells and evapotranspiration. Tschinkel (1963) and Daniel (1976) present methods to compute evapotranspiration for short periods (several months) based on the difference between actual observed streamflow and the theoretical "potential streamflow" determined from the recession index. The recession index is the time required for natural ground-water discharge to a stream (base flow) to decline through one log cycle (decline of 90 
percent) - in the absence of any evapotranspiration, pumping, or recharge.

Using larger versions of figures 11 and 13 , the author estimated the recession index for the Mojave River to be about 36 years at the Lower Narrows and about 40 years at Afton Canyon. Thus, without any recharge, evapotranspiration, or pumping, base flow of the Mojave River would decline 90 percent during a 36- to 40-year period (about a 6-percent annual decline). The recession index was computed from the slope of a line drawn through the annual high wintertime base flows using several consecutive years not significantly affected by storm runoff and aquifer recharge (for example, see water years 1948-51 in fig. 11 and water years 1953-57 in fig. 13). The winter-time high base flow occurs each year when the depletion effects of evapotranspiration and pumping are at a minimum.

Streamflow hydrographs of selected years with little storm runoff are shown in figures 32 and 33.

"Potential base flow" equivalent to the recession index line described above represents the highest wintertime streamflow, exclusive of any stormflow. For convenience of computation, potential base flow is assumed to be constant each water year rather than declining about 6 percent annually. With minor adjustments during short periods of storm runoff, the annual streamflow depletion is the difference between potential base flow and the actual daily mean discharges. For the Mojave River at Afton Canyon

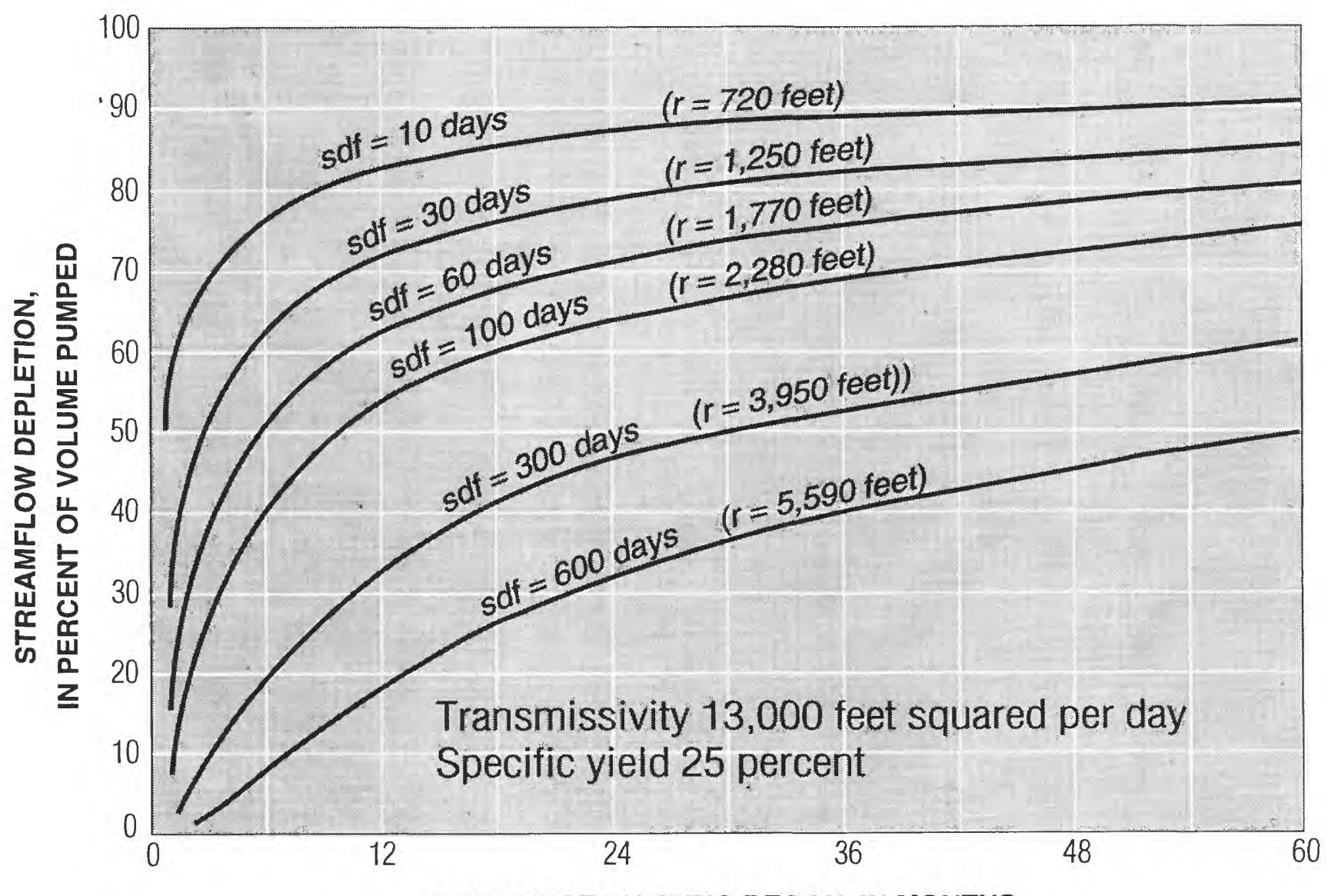

TIME SINCE PUMPING BEGAN, IN MONTHS

Figure 31. Streamflow depletion by a well that is pumped continuously for 60 months for various stream-depletion factors (sdf) and distances (r) from a stream. (Modified from Burns, 1983.) 
(fig. 32), the annual streamflow depletion is mainly due to evapotranspiration, as the gaging station is about $15 \mathrm{mi}$ downstream from any significant pumping from the flood-plain aquifer. Also, the base flow is derived from ground-water discharge along a 1-mile reach directly upstream from the gage. On the other hand, the streamflow depletion at the Lower Narrows (fig. 33) is partly due to evapotranspiration, but it is mainly due to ground-water pumping.

Annual streamflow depletion of the Mojave River at Afton Canyon is shown in figure 34 for selected water years. Streamflow depletion was not estimated for years when stormflow precluded identification of the high wintertime base flow. The depletion is due mainly to transpiration of phreatophytes along a 2-mile reach upstream from the gaging station and, to a much lesser degree, to evaporation from the river along the 1-mile reach of nearly perennial flow above the gage. The phreatophytes in Afton Canyon, which derive their water supply from both soil moisture and ground water consist mainly of tamarisk or saltcedar (Tamarix sp.) but also include screw bean mesquite (Prosopic pubescent), honey mesquite ( $P$. glandulosa), saltgrass (Distichlis spicata), cottonwood (Populus fremontii), black willow (Salix nigra), and desert willow (Chilopsis linearis). The phreatophytes grow in varying densities in an area of about 300 acres upstream from the gaging station. As can be seen in figure 34 , evapotranspiration annually consumed 300 to 900 acre-ft of water from the flood-plain aquifer and averaged about 600 acre-ft. Annual evaporation directly from the river, as pointed out earlier, averages about 5 acre-ft.

The annual evapotranspiration estimates of 1 to $3 \mathrm{ft}$ represent the entire flood-plain environment. The average of $2 \mathrm{ft}$ probably is biased on the low side because evapotranspiration during years with significant wintertime stormflow was not estimated. These evapotranspiration rates agree fairly well with the results of a water-budget study along the Gila River flood plain in Arizona (Culler and others, 1982) and energy-budget evapotranspiration measurements

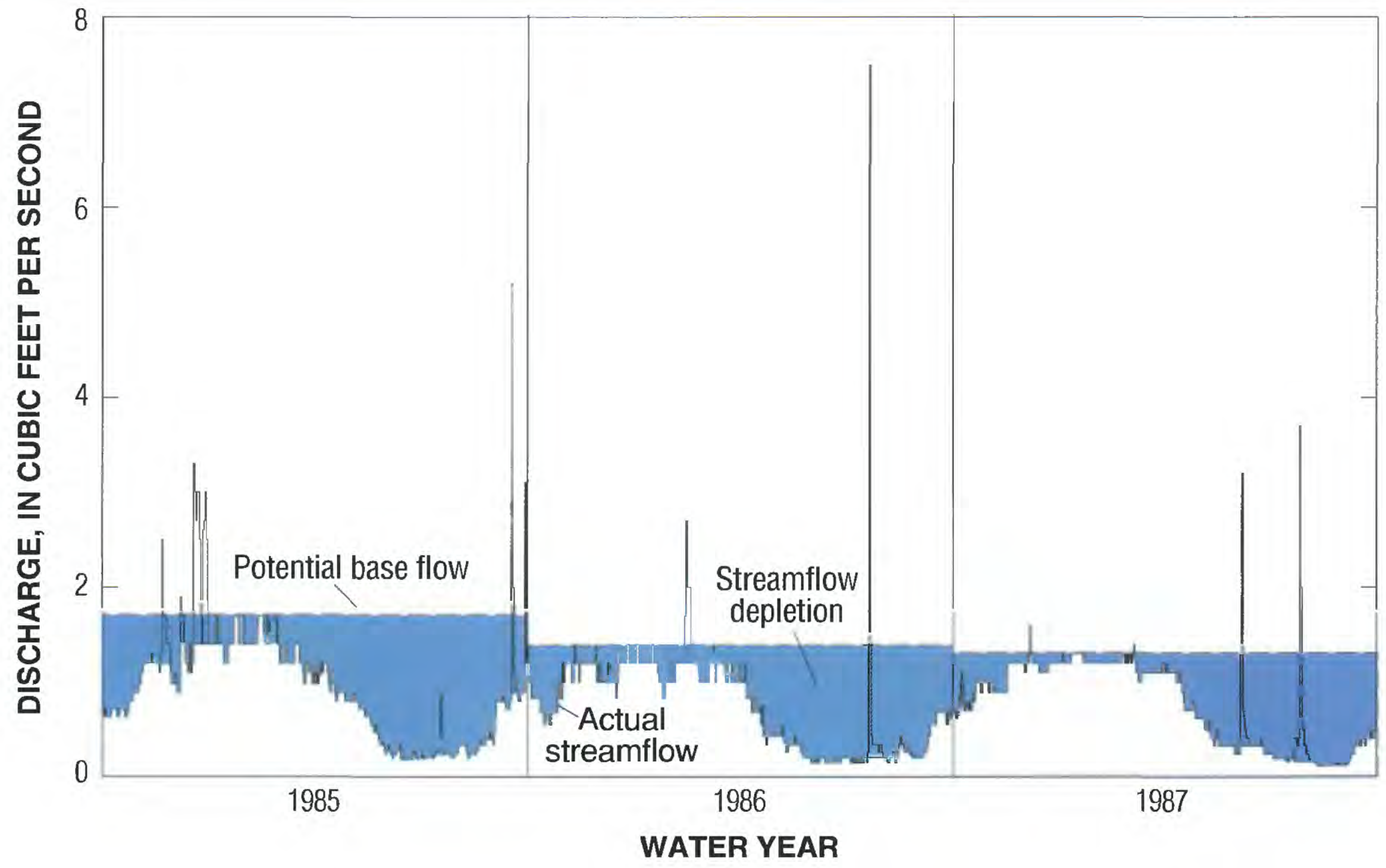

Figure 32. Estimated streamflow depletion for Mojave River at Aftor Canyon (gaging station 10263000) during water years 1985-87. 
along the Pecos River flood plain in New Mexico (Weeks and others, 1987). Agreement with studies of tank-measured evapotranspiration (Gatewood and others, 1950; van Hylckama, T.E.A., 1980) is poor. As pointed out by Weeks and others (1987, p. 7 and 30), the much larger evapotranspiration rates determined from tank experiments are probably due to oases effects on the tanks, and they probably represent the maximum rates of evapotranspiration that might occur with an unlimited water supply. Extrapolation of tankexperiment data to natural flood-plain environments may lead to erroneous conclusions concerning water consumption in the natural environment.

A comparison of annual streamflow depletion (fig. 34) and annual base flow at Afton Canyon (fig. 27 ) indicates a close correlation after about water year 1958. This suggests that, like base flow, evapotranspiration is greatest when the water table is highest. One might hypothesize that the more water readily available to the phreatophytes, the more they will consume. The data from most years after 1958 support this hypothesis. The lack of correlation between streamflow depletion and base flow prior to 1958 may be the result of a change in phreatophyte composition, but this is uncertain. An estimated 70 percent of the native riparian vegetation in Afton Canyon reportedly has been replaced by tamarisk (Johnson, 1989, p. 33). Tamarisk, a native of the Mediterranean area, was thought to have been introduced to the canyon in the early 1900 's; however, extensive tamarisk stands were not noted until the 1960 's. Stress on the native vegetation during water years 1948-65 (fig. 3), a period having only three years of above-normal precipitation, many have contributed to tamarisk proliferation in the canyon.

To the author's knowledge, the earliest mention of tamarisk growing along the lower main stem of the Mojave River was in the early 1950 's by the Bureau of Reclamation (1952). Tree-ring counts on three specimens of old-growth tamarisk collected for this study in a U.S. Bureau of Land Management controlled burn area about $1 \mathrm{mi}$ above the gaging station

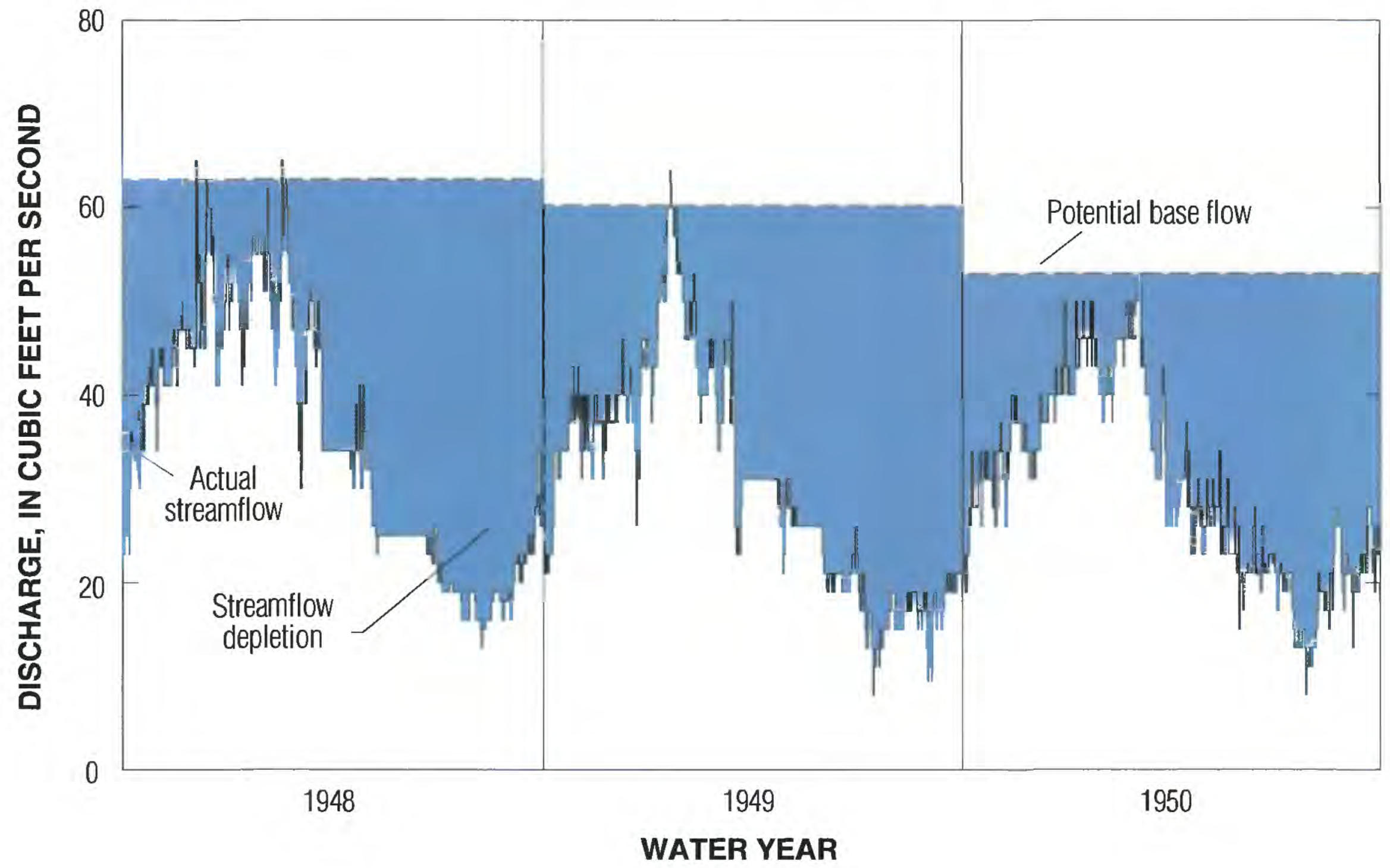

Figure 33. Estimated streamflow depletion for Mojave River at Lower Narrows (gaging station 10261500) during water years 1948-50. 
indicated germination dates of 1969, 1971, and 1973. However, older specimens of tamarisk may exist elsewhere in Afton Canyon.

The estimated annual streamflow depletion of the Mojave River near Victorville for selected water years is shown in figure 35 . Here again, streamflow depletion was not estimated for years when stormflows precluded identification of the high wintertime base flow. During the four years that depletion could be computed at the Upper Narrows (water years 1931, 33, 34, and 36), annual depletion averaged about 12,100 acre-ft. During the first four years that depletion could be computed at the Lower Narrows (water years 1939, 40, 42, and 46), annual depletion averaged 15,700 acre-ft. The 3,600-acre-ft difference in depletion between the Upper and Lower Narrows can be attributed to evapotranspiration from

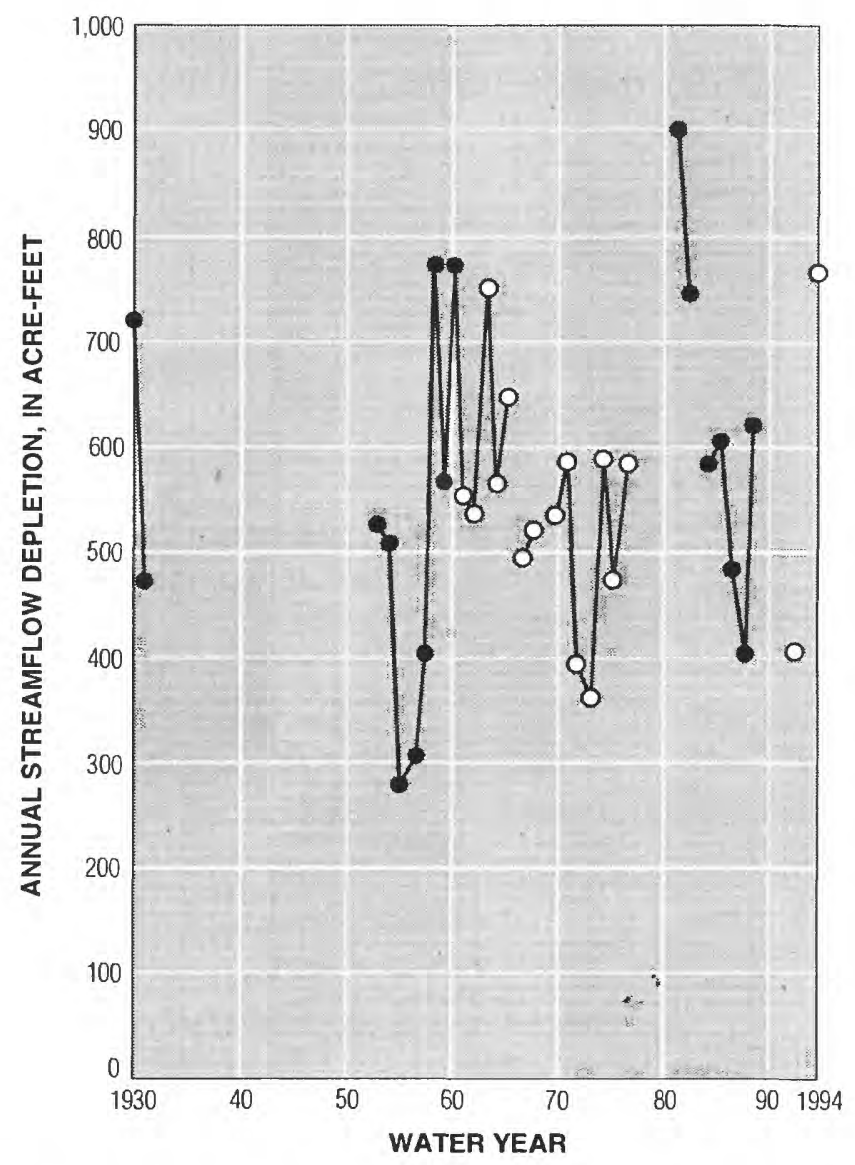

Figure 34. Streamflow depletion of Mojave River at Afton Canyon (gaging station 10263000) caused mainly by evapotranspiration during selected water years. (Open circle indicates no flow at times during water year; consecutive years joined by line.) about 800 acres of open water, marsh, cottonwoods, willows, and grassy bottomland and to ground-water pumping to irrigate about 200 acres of alfalfa.

Since the late 1930's, the annual depletion at the Lower Narrows has ranged from about 8,000 to 20,000 acre-ft and averaged about 15,000 acre-ft, but a general long-term decline has occurred. The reasons for this long-term decline are unclear. It could be due, in part, to a long-term decline in ground-water pumpage from the flood-plain aquifer upstream from the gaging station, although the lack of pumpage records do not allow this to be verified. The long-term decline in streamflow depletion could also be due, in part, to lowering of the water table in former swamps and wetlands near the Upper Narrows and conversion to a cottonwood and willow woodland that probably would consume less water (Myers, 1992).

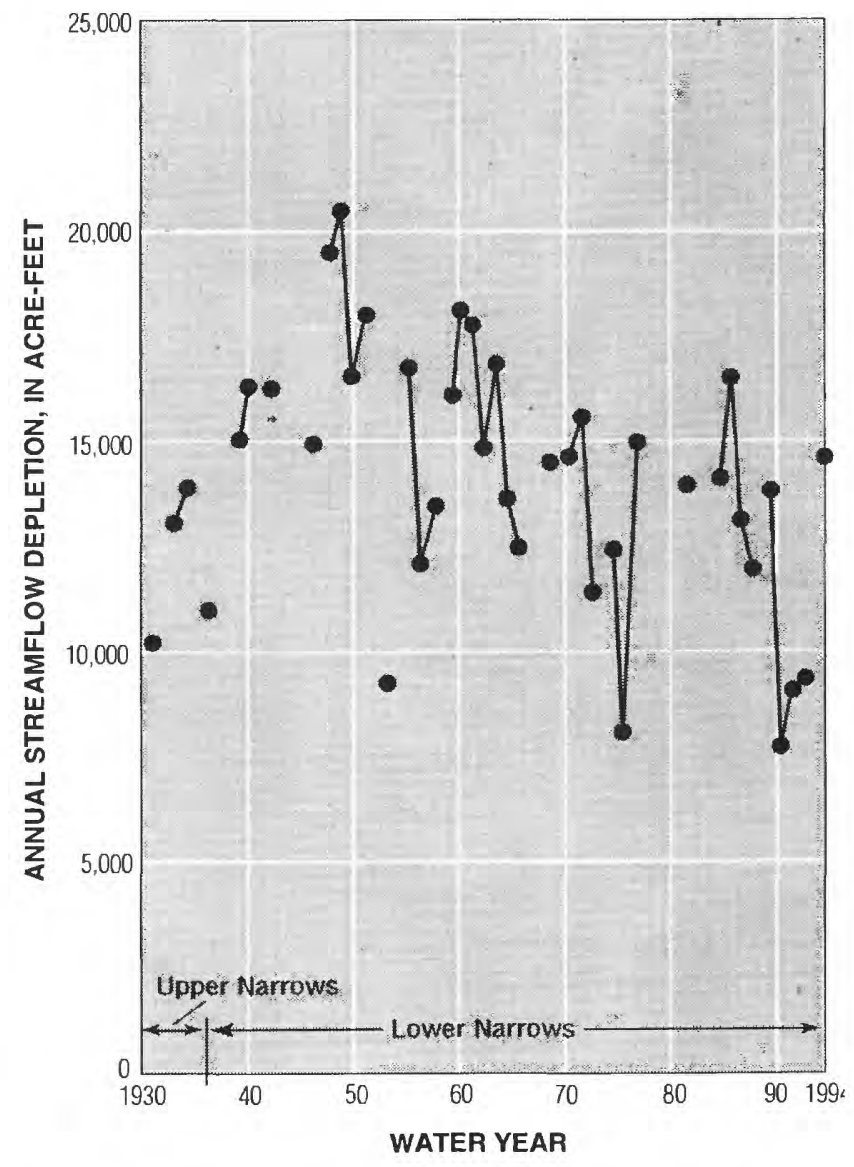

Figure 35. Streamflow depletion of Mojave River at Lower Narrows (gaging station 10261500) caused by ground-water pumping and evapotranspiration during selected water years. (Consecutive years joined by line.) 
It is not possible to directly separate streamflow depletion caused by evapotranspiration and depletion caused by ground-water pumping. However, if one assumes that evapotranspiration of the flood-plain environment near Victorville is similar to the evapotranspiration of the flood-plain environment at Afton Canyon, then 2,000 to 6,000 acre-ft would be consumed annually by the approximately 2,000 acres of open water, marsh, salt grass, cottonwoods, and willows upstream from the gaging station near Victorville, This would account for about one-quarter of the streamflow depletion since the late 1940's; the remaining three-quarters would be due to groundwater pumping.

Evapotranspiration along the main stem of the Mojave River has been estimated in the past using a variety of methods, all of which assume a constant annual water use of phreatophytes ranging from 3 to 7 $\mathrm{ft}$ (based on annual water-consumption estimates from tank experiments). The California Department of Public Works (1934) estimated that in 1929 approximately 7,800 acres of phreatophytes consumed 40,000 acre-ft of water. The Bureau of Reclamation (1952) estimated that annual evapotranspiration from about 11,000 acres of phreatophytes, open water, and wetted stream channel consumed about 35,000 acre-ft. A recent study completed for the California Department of Fish and Game estimates that about 8,500 acres of phreatophytes annually consumed about 30,000 acre- $\mathrm{ft}$ of water (Thomas W. Bilhorn, private consultant, written commun., 1993). On the basis of the evapotranspiration estimates for the flood-plain environment at Afton Canyon developed by this study, annual evapotranspiration probably varies by at least threefold, depending on prevailing hydrologic conditions. The estimate of 30,000 acre-ft probably is fairly accurate for "wet" years when the water table is high and large quantities of soil moisture are readily available for consumption. During periods of drought, however, total annual evapotranspiration along the Mojave River may be on the order of 10,000 acre-ft.

\section{FACTORS CONTROLLING RIVER- AQUIFER INTERACTION}

Many factors control the river-aquifer interaction, but probably the most important factors directly controlling ground-water recharge are the magnitude and duration of stormflows, the permeability of the streambed, and the volume of the unsaturated zone in the flood-plain aquifer. Flow occurred along the entire length of the main stem during the winter of 1993, and the water-table rise that occurred during this period of stress reflects the combined hydraulic effects of all these factors. From the water-table profile (fig. 22) and the water-table rise (fig. 29), one can see that along the upper and middle main stem, most of the ground-water recharge occurred along ephemeral reaches of the river where there was a thick unsaturated zone in the flood-plain aquifer. Along the lower main stem, even though much of the aquifer between Daggett and Camp Cady was unsaturated, recharge was relatively small. The lack of recharge along much of the lower main stem was due mainly to the presence of fine-grained, lowpermeability materials in the streambed and subsurface.

Ground-water pumping, in addition to directly depleting streamflow, is a major factor causing dewatering of the aquifer and creating unsaturated space in the flood-plain aquifer. Phreatophytes also deplete streamflow, but they have less immediate effect on ground-water recharge during periods of storm runoff. Phreatophytes grow in areas where the water table is within a few feet of land surface and where there is little storage space remaining in the aquifer.

\section{POTENTIAL FOR ARTIFICIAL RECHARGE}

Reaches of the river channel and flood plain that are hydraulically suitable for artificial recharge are limited. The most suitable reaches are those that naturally accept large quantities of recharge during periods of stormflow. The most favorable reach along the upper main stem extends from river miles 0 to 10 . Along the middle main stem, the reach from Helendale to Barstow (river miles 32 to 53) has favorable hydraulic conditions, and the reach between Hodge and Barstow (river miles 41 to 53) appears to be the most favorable. Along the lower main stem, the reach between Barstow and the Calico-Newberry Fault (river miles 53 to $\mathbf{7 2}$ ) has some potential for artificial recharge, but storage space in the aquifer is relatively small because of a shallow water table and a narrow flood plain along much of this reach.

The first $10 \mathrm{mi}$ of the upper main stem already is receiving artificial recharge by releases of imported water from Silverwood Lake and from the Morongo 


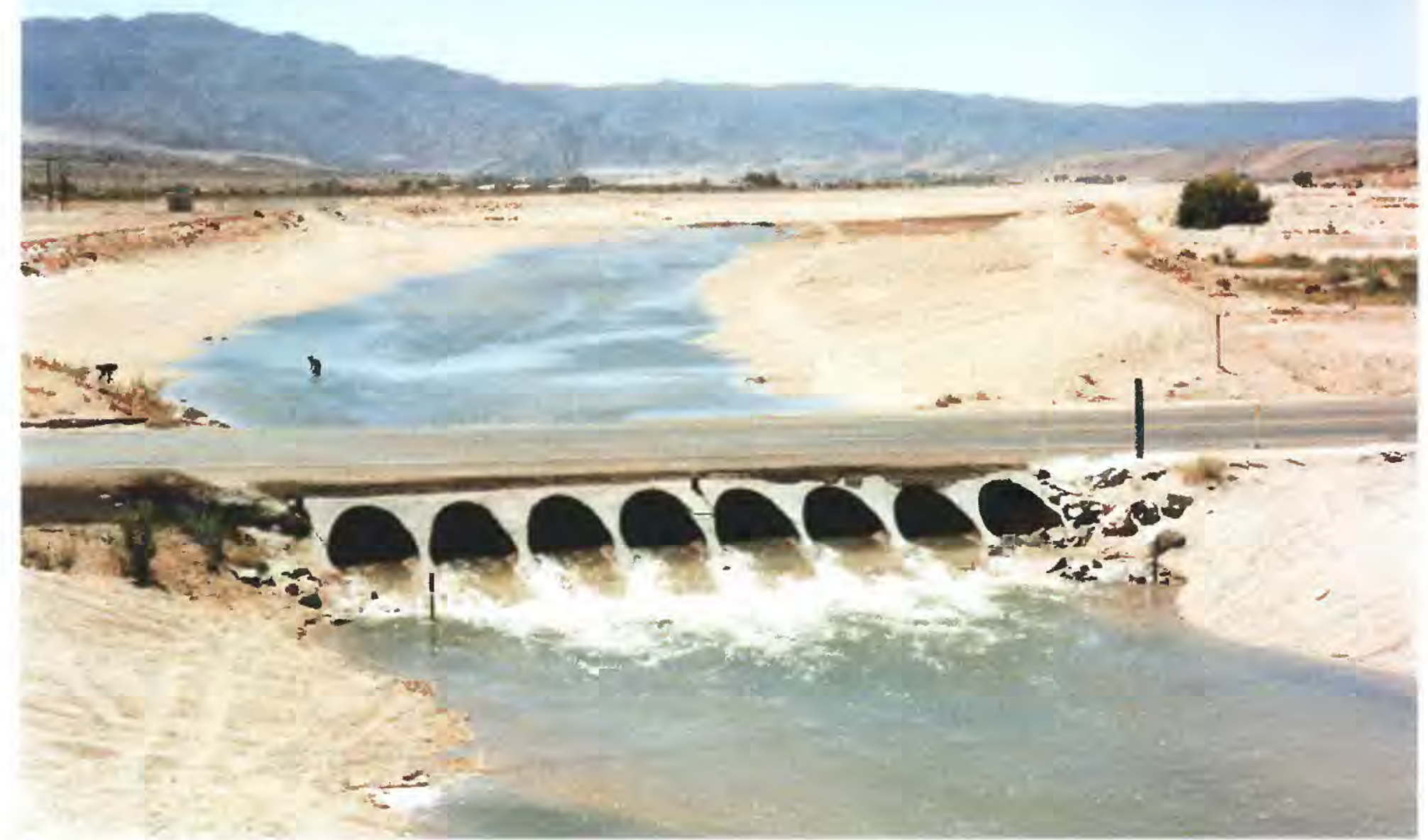

Figure 36. Mojave Water Agency's release of imported water to upper main stem of Mojave River near river mile 4, August 29, 1994. (View looking upstream with dry river channel in background. Discharge about 60 cubic feet per second.)

Basin Pipeline (fig. 36). In both cases, the river channel itself is being utilized to convey and percolate the imported water. Because the water table was several tens of feet below land surface even after the large quantity of recharge during water year 1993 and the flood plain is one-half mile or more in width, additional artificial recharge in this reach is possible.

Along the middle main stem, the Mojave Water Agency has conducted percolation tests at pond sites near Hodge and Lenwood. The ponds are located on the adjacent flood plain rather than on the river channel itself. Results of the two tests are favorable, although a source of recharge water is not yet available.

A source of water also is not yet available for artificial recharge along the lower main stem. Because very little water seems to percolate through the streambed during storm runoff along much of the lower main stem, it may not be possible to use the river channel or ponds for the percolation of imported water. The reach between Daggett and river mile 80 contains considerable storage space (see fig. 22), but additional testing would be necessary to identify an acceptable site and means for artificial recharge.

\section{CONCLUSIONS}

The Mojave River and the alluvial aquifer beneath its flood plain are in excellent hydraulic connection in many areas; a change in the flow conditions in one affects the other. The flood-plain aquifer receives virtually all of its recharge from the river, and most of the water originates in the headwaters. Annual recharge along the upper main stem averaged about 46,000 acre-ft during water years 1931-94, and recharge along the middle main stem averaged about 39,000 acre-ft during the same period. During the 44 years that annual recharge was estimated along the lower main stem, it averaged about 11,000 acre-ft.

Virtually all of the recharge water is eventually consumed by ground-water pumping and evapotranspiration. During 1994, ground-water pumpage from the flood-plain aquifer was about 120,000 acre-ft. 
Annual evapotranspiration probably ranges from about 10,000 acre-ft during drought years to perhaps as much as 30,000 acre- $\mathrm{ft}$ during years of large stormflows and high-water-table conditions.

Ground-water pumping and evapotranspiration cause both seasonal and long-term depletion in streamflow. The depletion in streamflow is most evident at the Lower Narrows and Afton Canyon where water from the flood-plain aquifer discharges naturally to the river. Since the late 1940's, annual streamflow depletion at the Lower Narrows has varied from about 8,000 to 20,000 acre-ft and averaged about 15,000 acre-ft. Annual base flow at the Lower Narrows has declined from an average of about 26,000 acre-ft during water years $1937-42$ to about 11,000 acre-ft during water years 1993 and 1994. Most of the streamflow depletion at the Lower Narrows is attributed to ground-water pumping.

The magnitude and duration of stormflows, the permeability of the streambed, and the thickness and volume of the unsaturated zone in the flood-plain aquifer are the most important factors controlling ground-water recharge. Most of the recharge during water years 1992-94 occurred along ephemeral reaches of the upper and middle main stem where the streambed is permeable and where there was a thick unsaturated zone. Despite a large unsaturated zone beneath the flood plain along much of the lower main stem, recharge along the lower main stem was relatively small, even during years with large stormflows. This lack of recharge is due mainly to the presence of fine-grained, low-permeability materials in that reach of the streambed. The most favorable reaches of the river for artificial recharge, using either percolation ponds on the flood plain or the river channel itself, are those that receive large quantities of recharge naturally from streamflow.

\section{REFERENCES CITED}

Barnes, B.S., 1939, The structure of discharge recession curves: American Geophysical Union Transactions, v. 20, p. $721-725$.

1940, Discussion on analysis of run-off characteristics by O.H. Meyer: American Society of Civil Engineers, v. 105, p. 104-106.
Buono, Anthony, and Lang, D.J., 1980, Aquifer recharge from the 1969 and 1978 floods in the Mojave River Basin, California: U.S. Geological Si'vvey Open-File Report 80-207, 25 p.

Bureau of Reclamation, 1952, Report on Victor Project, California: Boulder City, Nevada, Rerional Director's Report, 42 p.

Burns, A.W., 1983, Simulated hydrologic effects of possible ground-water and surface-water manasement alternatives in and near the Platte River, south-central Nebraska: U.S. Geological Survey Professional Paper 1277-G, $30 \mathrm{p}$.

California Department of Public Works, Division of Water Resources, 1934, Mojave River invest: gation: Bulletin 47, $249 \mathrm{p}$.

Chow, V.T., 1964, Handbook of applied hy łrology: New York, McGraw-Hill.

Coues, Elliott, 1900, On the trail of a Spanish pioneer: The diary and itinerary of Francisco Garcé (missionary priest) in his travels through Sonora, Arizona, and $\mathrm{Cal}-$ ifornia, 1775-1776: New York, Franc's P. Harper, 2 vols., $499 \mathrm{p}$.

Culler, R.C., Hanson, R.L., Myrick, R.M., Turner, R.M., and Kipple, F.P., 1982, Evapotranspirction before and after clearing phreatophytes, Gila River flood plain, Graham County, Arizona: U.S. Geolc rical Survey Professional Paper 655-P, $67 \mathrm{p}$.

Daniel, J.F., 1976, Estimating ground-wate- evapotranspiration from streamflow records: Water Resources Research, v. 12, no. 3, p. 360-364.

Daniel, J.F., Cable, L.W., and Wolf, R.J., 1970, Ground water-surface water relation during periods of overland flow: U.S. Geological Survey Professional Paper 700B, p. 219-223.

Dawdy, D.R., and Burkham, D.E., 1970, Error analysis of streamflow data for an alluvial stream: U.S. Geological Survey Professional Paper 655-C, 13 p.

Dibble, E.F., 1967, Mojave Water Agency, water production verification program: Redlands, California, $39 \mathrm{p}$.

Earle, David, 1992, Overview of the histor', of the upper Mojave River area, in Natural resources inventory of the Mojave River corridor: Riverside, California, Tierra Madre Consultants, Inc., p. 15-72.

Gatewood, J.S., Robinson, T.W., Colby, B.R., Hem, J.D., and Halpenny, L.C., 1950, Use of water by bottomland vegetation in lower Safford Vallev, Arizona: U.S. Geological Survey Water-Supply Paper 1103, 210 p.

Hardt, W.F., 1971, Hydrologic analysis of 1 Mojave River basin, California, using electric analog model: U.S. Geological Survey Open-File Report, 84 p.

Hedman, E. R., 1970, Mean annual runoff as related to channel geometry of selected streams in California: U.S. Geological Survey Water-Supply Paper 1999-E, $17 \mathrm{p}$. 
James, John, 1992, Precipitation/evaporation climatology of the Mojave Water Agency: Apple Valley, California, Mojave Water Agency, 21 p., 1 pl.

Jenkins, C.T., 1968a, Computation of rate and volume of stream depletion by wells: U.S. Geological Survey Techniques of Water-Resources Investigations, book 4, chap. D1, 17 p.

$1968 \mathrm{~b}$, Techniques for computing rate and volume of stream depletion by wells: Ground Water, v. 6, no. 2, p. 37-46.

Johnson, H.E., 1989, Management plan for Afton Canyon Natural Area and the surrounding area: Barstow, California, Bureau of Land Management, $66 \mathrm{p}$.

Linsley, R.K., Jr., Kohler, M.A., and Paulhus, J.L.H., 1975, Hydrology for engineers: New York, McGraw-Hill, 2d ed., $482 \mathrm{p}$.

Mullen, J.R., Hayes, P.D., and Agajanian, J.A., 1994, Water resources data--California. Water year 1993: U.S. Geological Survey Water-Data Report CA-93-1, v. 1, $440 \mathrm{p}$.

Myers, S.J., 1992, Biological inventory of the Mojave River corridor in Natural resources inventory of the Mojave River corridor: Riverside, California, Tierra Madre Consultants, Inc., $47 \mathrm{p}$.

National Oceanic and Atmospheric Administration, 1982, Evaporation atlas for the contiguous 48 United States: NOAA Technical Report NWS 33, 26 p., 4 pl.

Pool, D.R., and Eychaner, J.H., 1995, Measurements of aquifer-storage change and specific yield using gravity surveys: Ground Water, v. 33, no. 3, p. 425-432.

Searcy, J.K., 1959, Flow-duration curves: U.S. Geological Survey Water-Supply Paper 1542-A, 33 p.
Slichter, C.S., 1905, Field measurements of the rate of movement of underground waters: U.S. Geological Survey Water-Supply and Irrigation Paper 140, p. 5564.

Thompson, D.G., 1929, The Mohave Desert region, California--a geographic, geologic, and hydrologic recc nnaissance: U.S. Geological Survey Water-Supply Prner $578,759 \mathrm{p}$.

Torres, John, 1992, Cultural resources sensitivity study of the Mojave River corridor, San Bernardino County, California in Natural resources inventory of the Mojave River corridor: Riverside, California, Tierra Madre Consultants, Inc., 101 p.

Tschinkel, H. M., 1963, Short-term fluctuation in streamflow as related to evaporation and transpiration: Journal of Geophysical Research, v. 68 , no. 24, p. 64596469.

van Hylckama, T.E.A., 1980, Weather and evapotran `niration studies in a saltcedar thicket, Arizona: U.S. Geological Survey Professional Paper 491-F, 78 p.

Walker, C.J., 1986, Back door to California--the story of the Mojave River Trail: Barstow, California, Mojave River Valley Museum Association, 337 p.

Wallace, R.B., Darama, Yakup, and Annable, M.D., 1990, Stream depletion by cyclic pumping of wells: Y'ater Resources Research, v. 26, no. 6, p. 1263-1270.

Weeks, E.P., Weaver, H.L., Campbell, G.S., and Tanner, B.D., 1987, Water use by saltcedar and by replacement vegetation in the Pecos River floodplain between Acme and Artestia, New Mexico: U.S. Geolog inal Survey Professional Paper 491-G, 33 p. 